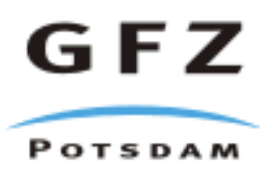

Originally published as:

Krienitz, M.-S., Trumbull, R. B., Hellmann, A., Kolb, J., Meyer, F. M., Wiedenbeck, M. (2008): Hydrothermal gold mineralization at the Hira Buddini Gold Mine, India: constraints on fluid sources and evolution from boron isotopic compositions of tourmaline. - Mineralium Deposita, 43, 4, 421-434

DOI: 10.1007/s00126-007-0172-0. 


\title{
Hydrothermal gold mineralization at the Hira Buddini gold mine, India: constraints on fluid evolution and fluid sources from boron isotopic compositions of tourmaline
}

\author{
M.-S. KRIENITZ*, R.B. TRUMBULL \\ GeoForschungsZentrum Potsdam, Telegrafenberg, 14473 Potsdam, Germany
}

\begin{abstract}
A. HELLMANN
Institut für Mineralogie und Lagerstättenlehre, RWTH Aachen, 52056 Aachen, Germany

J. KOLB

Department of Economic Geology, Geological Survey of Denmark and Greenland, 1350 Copenhagen K, Denmark
\end{abstract}

F.M. MEYER

Institut für Mineralogie und Lagerstättenlehre, RWTH Aachen, 52056 Aachen, Germany

M. WIEDENBECK

GeoForschungsZentrum Potsdam, Telegrafenberg, 14473 Potsdam, Germany

* Communicating author: E-mail: krieni@gfz-potsdam.de, Telephone: +49 (0)331 288 1468. Fax: +49(0)331288 1474 


\section{Abstract}

We determined the boron isotope and chemical compositions of tourmaline from the Hira Buddini gold deposit within the Archean Hutti-Maski greenstone belt in southern India in order to investigate the evolution of the hydrothermal system and to constrain its fluid sources. Tourmaline is a minor but widespread constituent in the inner and distal alteration zones of metabasaltic and metadacite host rocks associated with the hydrothermal gold mineralization. The Hira Buddini tourmaline belongs to the dravite-schorl series with variations in $\mathrm{Al}, \mathrm{Fe} /(\mathrm{Fe}+\mathrm{Mg}), \mathrm{Ca}$, $\mathrm{Ti}$ and $\mathrm{Cr}$ contents that can be related to their host lithology. The total range of $\delta^{11} \mathrm{~B}$ values determined is extreme, from $-13.3 \%$ to $+9.0 \%$ but $95 \%$ of the values are between -4 and $+9 \%$. The boron isotope compositions of metabasalt-hosted tourmaline shows a bimodal distribution with peak $\delta^{11} \mathrm{~B}$ values at about $-2 \%$ and $+6 \%$. The wide range and bimodal distribution of boron isotope ratios in tourmaline require an origin from at least two isotopically distinct fluid sources, which entered the hydrothermal system separately and were subsequently mixed. The estimated $\delta^{11} \mathrm{~B}$ values of the hydrothermal fluids, based on the peak tourmaline compositions and a mineralization temperature of $550^{\circ} \mathrm{C}$, are around $+1 \%$ and $+10 \%$. The isotopically lighter of the two fluids is consistent with boron released by metamorphic devolatilization reactions from the greenstone lithologies, whereas the ${ }^{11} \mathrm{~B}$-rich fluid is attributed to degassing of I-type granitic magmas that intruded the greenstone sequence, providing heat and fluids to the hydrothermal system.

Key words: Boron isotopes, orogenic gold deposits, Dharwar craton, India, tourmaline 


\section{Introduction}

The Hira Buddini gold deposit, like many others in the late Archean granitegreenstone belts of southern India, belongs to the genetic type of orogenic lodegold deposits (e.g. Nesbitt and Muehlenbachs 1989; Groves 1993; Wang et al. 1993). The source and nature of ore fluids in these deposits are still a matter of debate, the two most commonly proposed alternatives being metamorphic devolatilization of the greenstone lithologies during regional metamorphism, with mineralization after the peak metamorphic stage (Groves and Phillips 1987; Wyman and Kerrich 1988), and release of magmatic fluids from spatially associated granitic intrusions (Burrows and Spooner 1987; Wang et al. 1993). Tourmaline is a common gangue mineral in Hira Buddini and other Archean orogenic gold deposits worldwide (e.g. Müller and Groves 1991; Ridley et al. 1996; Slack 1996; McCuaig and Kerrich 1998; Eilu et al. 1999; Jiang et al. 2002). Indeed, the close association of tourmaline with gold mineralization in Archean lode gold deposits has led to tourmaline being employed as a pathfinder mineral in exploration (e.g. King and Kerrich 1989; Jiang et al. 2002). The wide stability range of tourmaline, its resistance to alteration, and its compositional variability make the mineral a useful geochemical tracer (Henry and Guidotti 1985; Slack 1996). Tourmaline can be particularly valuable for studies of hydrothermal systems because it is the main host for boron in most rocks and the boron isotopic composition is sensitive to changes in fluid source, $\mathrm{P}-\mathrm{T}$ conditions of crystallization, and phase changes such as boiling or fluid unmixing (e.g. Palmer and Swihart 1996; Slack 1996; Smith and Yardley 1996; Palmer and Slack 1989; Jiang et al. 1999; Jiang et al. 2002). 
In this contribution we present the first study of chemical and boron isotope compositions of tourmaline from gold mineralization in the Hira Buddini deposit from the Hutti-Maski greenstone belt, with the aim to shed light on the source of mineralizing fluids. There is overall consensus among workers studying gold deposits from the Hutti-Maski greenstone belt and others in the Dharwar craton, that gold was leached from the wall rocks during metamorphic events and was transported and concentrated in the sites of mineralization by regionally extensive shear zones (Roy 1991; Biswas 1990b; Giritharan and Rajamani 1998). However, Kolb et al. (2005) determined two temporally distinct hydrothermal events in the Hutti gold mine, and related the early fluid to amphibolite-facies greenstone assemblages (metamorphic fluid), and the later stage to a craton-wide magmatic event involving granite intrusions (magmatic fluid). We show below that this twofluid model is supported by our B-isotope results from the Hira Buddini deposit as well.

\section{Geological setting}

Hira Buddini is located within the Hutti-Maski greenstone belt, one of several late Archean (ca. 2.6 to $2.9 \mathrm{Ga}$ ) greenstone belts in the eastern Dharwar craton of southern India that host important mesothermal gold deposits (i.e. Kolar, Sandur, Ramagiri: Siddaiah and Rajamani 1989; Manikyamba et al. 2004). The Dharwar greenstone belts typically consist of $>90 \%$ basic metavolcanic rocks with minor intercalated felsic units, and subordinate clastic metasediments (quartz-mica schists and phyllites, minor quartzites) and Fe-rich metacherts (iron formation). Regional metamorphism at greenschist to amphibolite grade and multiple folding events were predominantly contemporaneous with the development of regional 
brittle-ductile shear zones which were of major importance for the gold mineralization as described below. Surrounding and intruding the greenstone belts are syn- to post-kinematic calc-alkaline granite intrusions with ages of 2.5 to 2.6 Ga (Chadwick et al. 2000; Jayananda et al. 2000). The geologic association, elongate form of the greenstone belts and geochemical characteristics of metabasalts and associated felsic metavolcanic rocks suggest formation in an arc setting (Chadwick et al. 2000; Pal and Mishra 2002; Manikyamba et al. 2004; Rogers et al. 2007) although there are also proponents of a plume origin for the magmatism (Jayananda et al. 2000; Chardon et al. 2002).

The Hutti-Maski belt is currently the economically most important goldproducing greenstone belt in India. It lies between about $76.5^{\circ}$ and $77^{\circ} \mathrm{E}$ and $16.3^{\circ}$ and $15.5^{\circ} \mathrm{N}$, has an elongate hooked form due to superposed folding, and a maximum E-W extent of about $45 \mathrm{~km}$ and a strike length of about $85 \mathrm{~km}$ from N to $\mathrm{S}$ (Fig. 1). The belt is bounded to the north and east by the younger Yelagatti and Kavital granitoids (metaluminous I-type, see Srikantia 1995; Rogers et al. 2007), whereas its southern and western boundaries are mostly older basement lithologies, i.e. the Peninsular gneiss (2.9 - 3.4 Ga: Beckinsale et al. 1980; Friend and Nutman 1991). The main rock types within the Hutti-Maski greenstone belt are highly deformed, pillow-bearing volcanic rocks of basaltic to minor intermediate (dacite-trachyte) compositions, and subordinate metasediments. Peak metamorphism reached conditions of the amphibolite facies (Kolb et al. 2005), and the rocks were retrograded to greenschist facies in shear zones. Geochronological data from the Hutti-Maski greenstone belt are rare but a SHRIMP weighted mean ${ }^{207} \mathrm{~Pb} /{ }^{206} \mathrm{~Pb}$ age of $2576 \pm 12 \mathrm{Ma}$ from zircon in a granodiorite clast of conglomerate, which probably forms the base of the schist belt, is interpreted by Vasudev et al. (2000) to be the maximum age of the belt. 
Rogers et al. (2007) dated metarhyolites from the Hutti gold mine in the northern sector of the greenstone belt. They report a minimum magmatic age of $2586 \pm 59$ Ma and interpreted a zircon age of $2543 \pm 9 \mathrm{Ma}$ as representing the age of intrusion of the Kavital granitoid, which in turn is intruded by the Yelagatti granite

Fig. 1 (Srikantia 1995).

\section{Mineralization and tourmaline occurrences}

Hira Buddini is one of three gold deposits in the north-eastern part of the HuttiMaski greenstone belt, the others being the Uti deposit (Mishra et al. 2005) and Hutti, the largest active gold mine in India (Fig. 1). These three deposits are very similar in their lithologic and mineralogic character of host rocks, ores and alteration assemblages. Gold occurs with a sulfide assemblage of pyrite, arsenopyrite, pyrrhotite, chalcopyrite and sphalerite in quartz or quartz-carbonate veins located in steeply-dipping brittle-ductile shear zones. Fluid inclusion studies and geothermometry calculations from ore and alteration assemblages indicate a temperature range of $350^{\circ}$ to $500^{\circ} \mathrm{C}$ for mineralization, and there is evidence in all three deposits for heterogeneous fluids (Mishra et al. 2005; Kolb et al. 2004; this study). Because of its economic importance, the Hutti deposit is by far the most extensively studied, making it an important point of reference for metallogenetic models of gold in the Hutti-Maski greenstone belt (e.g. Roy 1991; Pal and Mishra 2002; Kolb et al. 2004; Kolb et al. 2005). Tourmaline is not an important gangue mineral in the Hutti deposit in contrast to Hira Buddini, and it has only been described as a replacement mineral after biotite in the inner, chlorite-zone alteration (Kolb et al. 2005). 
The main gold lodes in the Hira Buddini deposit occur within a steeply-dipping ENE-WSW trending shear zone at the thrust contact between metabasalts, metadacites and metagabbros. The shear zone has a known lateral extent of about $600 \mathrm{~m}$. Gold lodes within it have been proven along a strike length of $400 \mathrm{~m}$ and to a depth of $140 \mathrm{~m}$. The width of the mineralized zone varies between 1 and $3.6 \mathrm{~m}$. Reported reserves are 0.25 million tonnes of ore at a grade of $7.9 \mathrm{~g} / \mathrm{t}$ (Geological Survey of India). Lithologically, gold mineralization is restricted to metavolcanic host rocks, i.e. amphibolites, metadacites and rarely garnet-biotite schists. The ore paragenesis is dominated by pyrite, with minor chalcopyrite, rare sphalerite, and gold. Gold occurs in the form of native gold grains in quartz veins or as overgrowths on pyrite in wall-rock alteration zones.

Wall-rock alteration is widespread at Hira Buddini and the alteration assemblages and replacement textures indicate two stages of mineralization, both containing gold although the early phase appears to be the more significant (Hellmann et al. 2005). Early, amphibolite-facies alteration zones (biotite-K-feldspar-albiteactinolite-tourmaline-calcite) are associated with extensional quartz and calcite veins. Temperature estimates for this stage are about 510 to $590^{\circ} \mathrm{C}$ based on fluid inclusion studies, ductile deformation of albite and observation of Dauphiné twinning in quartz ( $\alpha-\beta$ transition, Hellmann et al. 2005). The presence of both saline (halite-bearing) and carbonic $\left(\mathrm{H}_{2} \mathrm{O}-\mathrm{CO}_{2}-\mathrm{CH}_{4}\right)$ fluid inclusions may indicate unmixing or multiple fluids. Greenschist-facies alteration (chlorite-albitetourmaline-quartz) in association with late-stage quartz veins overprints the earlier zones. Sulfides and gold occur in this phase of alteration also but the volumes are insignificant compared with the earlier alteration phase.

In this study, samples from the alteration zones are designated as inner, proximal and distal based on their degree of alteration and deformation as well as spatial 
relationship to mineralized veins. However, because of the locally pervasive, 3-D complexities of shear zone geometry and because not all quartz veins show the same intensity of wallrock alteration, it is more meaningful to define the three alteration zones by their mineral assemblage. On this basis the distal zone is characterized by replacement of hornblende by chlorite and actinolite; the proximal alteration zone shows replacement of hornblende and plagioclase by actinolite, biotite, calcite and tourmaline; and the typical paragenesis of the inner alteration zone is biotite, K-feldspar and quartz (Hellmann et al. 2005).

\section{Tourmaline occurrence}

Hydrothermal tourmaline is widespread in all mineralized zones in the Hira Buddini deposit, both in the metadacite and metabasalt host lithologies. It forms either monomineralic tourmaline veinlets, tourmaline-rich clusters within altered wall rocks, or comb-structured gangue in association with quartz and calcite veins. None of the tourmaline is part of the unaltered wall rocks. Instead, tourmaline clearly shows replacement textures after primary amphiboleplagioclase assemblages, and tourmaline grains are intergrown with other alteration minerals such as calcite, quartz, pyrite, K-feldspar, biotite and apatite

Fig. 2 (Fig. 2).

Two tourmaline generations are distinguished. A first generation grew during the amphibolite-facies alteration phase, and a second generation is related to the later greenschist-facies hydrothermal event. The older generation typically occurs as subhedral, in part poikilitic grains that form tourmaline-rich clusters or zones within the wall rock (Figs. 2a-e). Some of the older tourmalines are broken and their cracks are sealed with quartz, subordinate hematite and chlorite. Color 
zoning is common, locally oscillatory and generally progressing from pale green to brown cores to grey or bluish rims. The second, younger tourmaline generation is represented by crystals occurring either in monomineralic tourmaline veins or as gangue minerals in close association with vein quartz and calcite (Figs. 2f-j). The younger tourmalines form fine-grained euhedral needles and are coloured in various shades of greenish-blue to light brown. Zonation in these grains is rare.

\section{Methods}

For this study a total of 82 tourmaline grains from 10 rock samples representing the main wall rock lithologies in different exploration levels of the Hira Buddini gold mine were investigated. Sample names and locations, host rock type, and a short petrographic description are given in the Electronic Supplementary Material (ESM Table 1 and ESM Fig. 1).

\section{Electron microprobe analysis}

Tourmaline compositions were determined by wavelength-dispersive electron microprobe analyses at the Institute of Mineralogy and Economic Geology, RWTH Aachen and at the GeoForschungsZentrum Potsdam. The RWTH analyses employed a JEOL JXA-8900R electron microprobe operated at $15 \mathrm{kV}$ accelerating voltage and $20 \mathrm{nA}$ beam current. Analyses performed at the GFZ Potsdam used a CAMECA SX-100 instrument with the same operating conditions as in Aachen. Tourmaline structural formulae were calculated by normalizing to 15 cations in the tetrahedral and octahedral sites $(\mathrm{T}+\mathrm{Z}+\mathrm{Y})$ according to the suggestion of Henry and Dutrow (1996). Representative tourmaline analyses are 
listed in Table 1 and the complete data set is given in the Electronic

Tab. 1 Supplementary Material (ESM Table 2).

\section{SIMS analysis}

The boron isotope compositions of tourmaline were analysed with a CAMECA ims6f SIMS ion microprobe at the GFZ Potsdam. After electron microprobe analysis, the samples were re-polished with alumina and distilled water to remove the carbon coat, then ultrasonically cleaned with high purity ethanol and coated with a $\sim 35 \mathrm{~nm}$ thick high purity gold coat. The use of a liquid nitrogen cold trap provided a secondary ion source pressure in the mid $10^{-10}$ Torr range. Specific domains for the isotopic analyses were identified both from petrographic microscope studies and from internal structures and zoning detected by chemical data or backscattered electron imaging. Wherever grain size permitted, care was taken that both rim and core compositions were measured. Boron isotopic analyses employed a nominally $12.5 \mathrm{kV}, 1 \mathrm{nA}{ }^{16} \mathrm{O}^{-}$primary beam which was focused to a $\sim 10 \mu \mathrm{m}$ spot on the sample surface. Prior to each analysis a 5 minute preburn was used in order to burn through the gold coat and to establish equilibrium sputtering conditions. The mass spectrometer was operated at mass resolving power $M / \Delta M \approx 1200$, sufficient to separate the isobaric interference of ${ }^{10} \mathrm{~B}{ }^{1} \mathrm{H}$ on the ${ }^{11} \mathrm{~B}$ mass station. A $150 \mu \mathrm{m}$ diameter contrast aperture, an $1800 \mu \mathrm{m}$ field aperture (equivalent to a $150 \mu \mathrm{m}$ field of view) and a $125 \mathrm{~V}$ energy window were used without voltage offset. These conditions resulted in a count rate for ${ }^{11} \mathrm{~B}$ of $\sim 400 \mathrm{kHz}$ on the electron multiplier to which a $16 \mathrm{~ns}$ deadtime correction was applied. A single analysis consisted of 50 scans of the peak stepping sequence 9.95 background $(0.1$ seconds per cycle $),{ }^{10} \mathrm{~B}(4 \mathrm{~s})$ and ${ }^{11} \mathrm{~B}(2 \mathrm{~s})$ resulting in a total 
analysis time of 10.5 minutes. Instrumental mass fractionation (IMF) as well as analytical precision and accuracy were determined by repeated analyses of tourmaline reference materials dravite (HS \#108796), elbaite (HS \#98144) and schorl (HS \#112566) from the Harvard Mineralogical Museum and B4 from the Istituto Geocronologia et Geochimica Isotopica. The assigned ${ }^{11} \mathrm{~B} /{ }^{10} \mathrm{~B}$ ratios of the Harvard reference standards were reported by Dyar et al. $(1998 ; 2001)$ and of the B4 standard by Tonarini et al. (2003b). During the analytical sessions for this study the internal precision for individual analyses was typically $\pm 0.5 \%$. External reproducibility on single reference samples averaged $1.2 \%(1 \sigma)$ and the variation in observed mass fractionation between the single reference samples was less than $1.4 \%$, which we believe to be the best estimate of the accuracy of the data set. Boron isotope compositions are reported in $\delta^{11} \mathrm{~B}$ notation $\left(\delta^{11} \mathrm{~B}=\left\{{ }^{11} \mathrm{~B} /{ }^{10} \mathrm{~B}_{\text {sample }}{ }^{\text {corr }}\right.\right.$ $\left./{ }^{11} \mathrm{~B} /{ }^{10} \mathrm{~B}_{\text {standard }}-1\right\} \times 1000$ ) relative to the reference material NBS 951, whose ${ }^{11} \mathrm{~B} /{ }^{10} \mathrm{~B}$ ratio is taken as 4.04362 (Cantanzaro et al. 1970). The results of the boron isotope analyses on the reference materials and samples are shown in the

Tab. 2 Electronic Supplementary Material (ESM Table 3) and in Table 2, respectively.

\section{Results}

\section{Tourmaline classification and major element variations}

For convenience in the data presentation and following discussions the tourmaline samples are divided into three groups depending on their generation of formation, the host lithology (basaltic vs. intermediate) and the type of alteration, as follows: Group 1 tourmaline comprises all younger generation grains, and have been found only in the metadacite host rocks where they occur in both the distal and inner alteration zones. Groups 2 and 3 are both related to the first-generation of 
tourmaline growth and both occur in metabasaltic host rocks. The distinction between them is that group 3 is located in the distal alteration zone and group 2 in the more highly altered proximal zone. Compositionally, the tourmaline from Hira Buddini belongs to the alkali group in the nomenclature of Hawthorne and Henry (1999), but as shown in Figures 3 and 4, there are important compositional

Fig. 3 differences among the three groups. In terms of the X-site occupancy (Fig. 3a), group 1 tourmaline (metadacite host) has the lowest Ca contents and the highest abundances of vacancies (up to $\sim 45 \%$ ). The proportion of $\mathrm{Ca}$ in $\mathrm{X}$-sites for group 3 tourmaline (metabasalt, distal alteration) reaches about $20 \%$ and the highest $\mathrm{Ca}$ abundance is in group 2 tourmaline (proximal alteration) reaching up to $45 \%$. The Hira Buddini tourmalines also show distinct compositions in the Al-Fe-Mg ternary diagram (Fig. 3b after Henry and Guidotti 1985). The three groups cluster in the middle of the diagram, but the group 1 tourmaline plots exclusively on the Al-rich side of the schorl-dravite join whereas group 2 and group 3 tourmaline describes a trend extending from the schorl-dravite line towards more Al-poor and Fe-rich compositions, indicating their formation from $\mathrm{Fe}^{3+}$-rich quartz-tourmaline, calc-silicate and metapelitic rocks, with the group 3 having the most extreme values along this trend. The $\mathrm{Fe} /(\mathrm{Fe}+\mathrm{Mg})$ and $\mathrm{Na} /(\mathrm{Na}+\mathrm{Ca})$ ratios nearly completely discriminate the three tourmaline groups. The young, metadacite-hosted tourmaline of group 1 has high $\mathrm{Na} /(\mathrm{Na}+\mathrm{Ca})$ ratios and $\mathrm{Fe} /(\mathrm{Fe}+\mathrm{Mg})$ generally less than 0.5 . Group 3 tourmaline has a wider range of $\mathrm{Fe} /(\mathrm{Fe}+\mathrm{Mg})$ than group 1 and lower $\mathrm{Na} /(\mathrm{Na}+\mathrm{Ca})$ ratios, and group 2 compositions are distinctive for their wide range of $\mathrm{Na} /(\mathrm{Na}+\mathrm{Ca}), \mathrm{Fe} /(\mathrm{Fe}+\mathrm{Mg})$ less than 0.5 , and a positive correlation between the two ratios (Fig. 4a). The heterogeneous $\mathrm{Na} /(\mathrm{Na}+\mathrm{Ca})$ ratios of the group 2 tourmaline are due mostly to variable Ca concentrations. 
Some insights on the crystal-chemical controls on compositional variability are illustrated in plots of X-site vacancies versus Fe and Al contents (Figs. 4d-f). The high $\mathrm{Al}$ contents in group 1 tourmaline, well in excess of the 6 cations per formula unit for ideal schorl-dravite (Figs. $4 \mathrm{~d}$ and f), correlate with X-site vacancies and this suggests that excess $\mathrm{Al}$ is charge-balanced by the magnesiofoitite substitution ( $\square, \mathrm{Al})(\mathrm{Na}, \mathrm{Mg})_{-1}$ rather than the elbaite component as might be implied by Figure 3b. Examination of the trends defined by data from tourmaline groups 2 and 3 in these plots suggest that the deviation from ideal schorl-dravite substitution towards low $\mathrm{Al}$ and high $\mathrm{Fe}$ is related by the exchange component $\left(\mathrm{Fe}^{2+}\right.$,

Fig. $\left.4 \quad \mathrm{Fe}^{3+}\right)(\mathrm{Mg}, \mathrm{Al})_{-1}$.

The minor constituents fluorine and $\mathrm{Cr}_{2} \mathrm{O}_{3}$ vary more extremely than the major elements (Figs. $4 \mathrm{~b}$ and c). Fluorine concentrations of near zero to $\sim 0.7 \mathrm{wt} \%$ are observed in group 1 tourmaline, whereas no tourmaline from the other groups contained $\mathrm{F}$ above the detection limit. Chromium contents in group 2 tourmaline are distinctly higher than in the other groups, reaching a maximum of $\sim 0.8 \mathrm{wt} \%$ $\mathrm{Cr}_{2} \mathrm{O}_{3}$ compared with $<0.1 \mathrm{wt} \%$ for the groups 1 and 3 (Fig. 4c). A comparison of $\mathrm{Cr}$ contents in the host rocks (inset, Fig. 4c) suggests that the $\mathrm{Cr}$ abundance in group 2 tourmaline is controlled by the composition of the host rocks, which is true for several other elements as well (Al, Fe, Ti - not shown).

\section{Boron isotope compositions}

The total range of $\delta^{11} \mathrm{~B}$ values determined from the Hira Buddini tourmaline samples is from $-13.3 \%$ to $+9.0 \%$, however values below $-4 \%$ are exceedingly rare (5 out of 99 analyses, see Fig. 5). Group 1 tourmaline (late generation, metadacite host) has the most heterogeneous B-isotope composition ( -4 to $+7 \%$ o 
$\delta^{11} \mathrm{~B}$, with one outlier at $-13 \%$ ). The average for all samples except this outlier is $0.2 \%$ ( $( \pm 2.8, \mathrm{n}=44)$. About $70 \%$ of the $\delta^{11} \mathrm{~B}$ values from group 1 analyses fall between about $-3 \%$ and $+2 \%$ whereby tourmaline samples from the inner alteration zone (sample 25313) are at the light end of this range, with $\delta^{11} \mathrm{~B}$ generally below $-2 \%$. Group 1 tourmaline from sample 26577 is relatively enriched in ${ }^{11} \mathrm{~B}$, with the majority ( $\sim 85 \%$ ) of $\delta^{11} \mathrm{~B}$ values being positive (Fig. 5 ). Group 2 tourmaline (metabasalt host, proximal alteration zone) is the most homogeneous and also the most distinctive in terms of $\delta^{11} \mathrm{~B}$ values, with all analyses falling between $+2 \%$ and $+9 \%$ (average $=+6.1 \% 0 \pm 2.1, \mathrm{n}=24)$. Finally, group 3 tourmaline, which is also hosted by metabasalt but occurs in the distal alteration zone, yields a range of $\delta^{11} \mathrm{~B}$ values overlapping group 1 tourmaline but with a slightly lower average value of $-2.7 \% 0 \pm 2.2(n=21$, except one outlier at -

Fig. $5 \quad 11.8 \%$ ).

Systematic correlations between chemical and boron isotopic compositions of tourmaline were not observed, with the exception of a negative correlation of $\delta^{11} \mathrm{~B}$ values with $\mathrm{MgO}$ and $\mathrm{CaO}$ in group 1 and 2 tourmaline (not shown). Boron isotopic zoning was checked for in all grains large enough for multiple SIMS analyses of core and rim regions, and some systematic trends were found although the average isotopic shift barely exceeds analytical error in many cases. No isotopic zoning was observed in group 1 tourmaline (late generation, metadacite host) but for the metabasalt samples (early generation, group 2 and 3) we observe zoning trends that differ depending on the position in the alteration zones. Thus, zoned tourmaline from the proximal alteration zone (group 2) generally displays heavier, i.e. ${ }^{11}$ B-rich, cores and lighter rims, the average shift being about $1.6 \%$, whereas tourmaline in the distal alteration zone (group 3), shows the opposite 
sense of zoning. Again, the average core-rim difference of about $1.3 \%$ is on the same order as the analytical uncertainty but the tendency is consistent.

The strong variation in boron isotopic composition among the hydrothermal tourmaline from Hira Buddini is a major result of this study and the subject of detailed discussion in the following section.

\section{Discussion}

\section{Boron isotope variation in tourmaline}

The boron isotopic compositions of tourmaline from the Hira Buddini gold mine are clearly far from homogeneous and there are systematic differences in terms of both the range and average compositions of the different tourmaline groups (Fig. 5). For a hydrothermal setting like Hira Buddini, there are two principal alternatives to explain the observed variability of $\delta^{11} \mathrm{~B}$ values in tourmaline: (1) tourmaline formation from a homogeneous fluid with variations of $\delta^{11} \mathrm{~B}$ due to factors controlling isotopic exchange and fractionation between tourmaline and fluid and/or other minerals in the paragenesis, and (2) tourmaline growth from a heterogeneous hydrothermal system with two or more fluids from isotopically distinct sources.

One important result of this study that must be explained is the large isotopic difference between the group 2 and 3 tourmaline. Both groups represent the amphibolite-facies alteration of metabasalt and their average $\delta^{11} \mathrm{~B}$ values differ by about 7\%o (Fig. 5). We consider first the hypothesis that the isotopic shift was caused by temperature differences or unmixing of an initially isotopically homogenous fluid. The experimental studies of tourmaline-water isotopic fractionation by Palmer et al. (1992) and Meyer et al. (2007) showed that tourmaline is preferentially enriched in ${ }^{10} \mathrm{~B}$ relative to a fluid at all temperatures 
examined and that a pressure dependence is either absent (Meyer et al. 2007) or minor, with higher pressure causing less fractionation (Palmer et al. 1992). Based on these studies, the temperature effect on isotope fractionation, for the ca. $100^{\circ} \mathrm{C}$ range of early stage tourmaline formation $\left(\mathrm{T}=510-590^{\circ} \mathrm{C}\right.$; Hellmann et al. 2005), is too small to explain the observed $7 \%$ o difference between the tourmaline groups 2 and 3. The possibility of unmixing of fluid and vapour during boiling, with subsequent fractionation of ${ }^{11} \mathrm{~B}$ and ${ }^{10} \mathrm{~B}$ between the two phases, can be addressed from experimental work of Spivack et al. (1990), who found negligible isotopic fraction above $425^{\circ} \mathrm{C}$. Thus, this process can also be ruled out for the isotopic difference. Rayleigh fractionation, whereby progressive tourmaline growth depletes the fluid reservoir in ${ }^{10} \mathrm{~B}$, would cause a shift in isotopic composition of late-stage fluids, and consequently in tourmaline formed from them, towards higher $\delta^{11} \mathrm{~B}$ values. Our study found no evidence for this process in zoned grains, and also, Rayleigh fractionation should produce a range of compositions rather than the bimodal distribution of groups 2 and 3. Finally, it is possible that changes in the fluid/rock ratio in the hydrothermal system could affect the boron isotope composition of tourmalines as the system shifts between rock-dominated and fluid-dominated modes. However, the comparison of tourmaline compositions from more and less-altered host rocks (high vs. low fluid/rock ratio) shows that the isotopic differences are minor and/or of opposite sense in different host rocks. Thus, for group 1 (metadacite hosted) tourmaline, the compositions of distal and inner zone samples overlap, and the inner zone has slightly lower $\delta^{11} \mathrm{~B}$ values (ca. $2 \%$ ), whereas in metabasalt host rocks, tourmaline from the proximal zone (group 2) has higher $\delta^{11} \mathrm{~B}$ values than those from the distal zone (group 3, see Fig. 5). We conclude that the expected variations in isotopic composition of hydrothermal tourmaline due to the fractionation processes outlined above will be too small to 
account for the observed variations at Hira Buddini, and in some cases the predicted effects are contrary to observation. Therefore, we suggest that the tourmaline isotopic compositions require the interaction of at least two fluids in the hydrothermal system as described in the following section.

\section{Multiple fluid hypothesis}

The involvement of two different hydrothermal fluids during tourmaline formation appears to be required for explaining the observed $\delta^{11} \mathrm{~B}$ variations of tourmaline within the Hira Buddini deposit, and there is independent support for this hypothesis from previous geochemical and petrologic studies. Kolb et al. (2005) reported two temporally distinct hydrothermal events in the Hutti gold mine, and related the fluids to amphibolite-facies greenstone assemblages, i.e. a metamorphic fluid, and to a magmatic event involving granite intrusions, i.e. a magmatic fluid. The key observation suggesting contrasting fluids in the Hira Buddini hydrothermal system is the large B-isotopic difference between group 2 and 3 tourmaline, both of which formed in the same host-rock lithology and under similar P-T conditions. One fluid is represented by group 3 tourmaline, with average $\delta^{11} \mathrm{~B}$ of $-2 \%$, whereas tourmaline of group 2 with average $\delta^{11} \mathrm{~B}$ values of about $+6 \%$ would typify the second fluid (Fig. 5). The fact that one fluid type dominates over the other depending on position of the samples in the alteration sequence (distal vs. proximal) suggests different access of the fluids into the system. For the metabasalt the isotopically heavy fluid had greater access to the more intense, proximal alteration zone. If two fluids were present simultaneously in the hydrothermal system it is likely that some mixing took place, which may explain the isotopic variations within each of the groups as well as the opposite sense of boron isotopic trends in zoned tourmaline from group 2 (light cores, 
heavy rims) versus that from group 3 (heavy cores, light rims). Thus, the core composition would be closer to the "end-member" of the respective fluids with the rims shifted slightly towards the intermediate, mixed composition. The boron isotope composition of the younger, group 1 tourmaline from metadacite (average $\delta^{11} \mathrm{~B}$ value $-0.2 \%$ ) suggests at first glance a dominance of the isotopically lighter fluid component, but considering the comparatively low temperature of formation for group 1 tourmaline $\left(\sim 350^{\circ} \mathrm{C}\right.$, Hellmann et al. 2005$)$, the fluid composition is actually close to that of the ${ }^{11} \mathrm{~B}$-rich tourmaline of group 2. Using the B-isotope fractionation factors between tourmaline and water from Palmer et al. (1992), the calculated fluid $\delta^{11} \mathrm{~B}$ for group 1 tourmalines would be about $+8 \%$ o for $\mathrm{T}=$ $350^{\circ} \mathrm{C}$ ) compared with $+10 \%$ for group 2 tourmaline (for $\mathrm{T}=550^{\circ} \mathrm{C}$ ). By contrast, the calculated $\delta^{11} \mathrm{~B}$ value of fluid precipitating group 3 tourmaline would be about $+1 \%$ (for $\mathrm{T}=550^{\circ} \mathrm{C}$ ). More quantitative modelling of fluid compositions for the Hira Buddini deposit is unwarranted given the large isotopic variability within each group, but these estimates show that a scenario of two isotopically distinct fluids can explain the overall shifts in $\delta^{11} \mathrm{~B}$ composition between the tourmaline groups. The variation within each group then reflects fluid mixing and/or isotopic fractionation during tourmaline formation.

\section{Implications for fluid sources}

An important first-order feature of the tourmaline studied is the overall enrichment in ${ }^{11} \mathrm{~B}$ compared with tourmaline from typical crustal rocks (S-type granites, felsic gneisses, metasedimentary rocks), whose $\delta^{11} \mathrm{~B}$ values are lower than $-10 \%$ (Palmer and Swihart 1996). The estimated neutral to positive values of $\delta^{11} \mathrm{~B}$ for boron in the hydrothermal fluids at Hira Buddini suggest that the 
dominant boron source is from components like juvenile igneous rocks, altered oceanic crust or marine sediments related to the Hutti-Maski greenstone-belt sequences and not from the cratonic basement.

As described in the previous section, at the conditions of tourmaline formation in the first stage of gold mineralization of $\sim 550^{\circ} \mathrm{C}$ and $\sim 500 \mathrm{MPa}$, the estimated $\delta^{11} \mathrm{~B}$ values for the two hydrothermal fluids precipitating group 2 and 3 tourmaline are about $+10 \%$ and $+1 \%$, respectively, using values for tourmaline-water fractionation from Palmer et al. (1992). The isotopically lighter fluid associated with tourmaline group 3 is in reasonable accord with the dominant $\delta^{11} \mathrm{~B}$ range for mafic volcanic rocks of about $-7 \%$ o to $+1 \%$ (e.g. Barth 1993; Chaussidon and Jambon 1994; Palmer and Swihart 1996). This can be interpreted in simplest terms as a metamorphic fluid with a boron isotopic signature derived from the metavolcanic country rocks at Hira Buddini.

The isotopically heavy fluid represented by group 2 tourmaline and by the younger group 1 tourmaline $\left(\delta^{11} \mathrm{~B}\right.$ values of about $+10 \%$ ) can be ascribed a magmatic origin related to the granitoids intruding the Hutti-Maski greenstones (Kolb et al. 2005). Tourmaline is not present in the Yelagatti and Kavital granitoids adjacent to the Hutti-Maski belt, so the B-isotopic composition of their magmatic fluids cannot be directly estimated. However, the lack of tourmaline in these intrusions by no means precludes a significant contribution of magmatic boron in the hydrothermal fluids since saturation of a granitic magma in tourmaline requires a peraluminous bulk composition and an advanced degree of chemical fractionation (Wolf and London 1997), neither of which conditions are met by the intermediate I-type granitoids of the Yelegatti and Kavital intrusions. Chadwick et al. (1996) argued that magmas of juvenile origin (i.e. mantlederived) are the dominant type in the eastern part of the Dharwar craton, including 
the Yelagatti and Kavital granitoids adjacent to the Hutti-Maski belt. Thus it is reasonable to assume that the B-isotopic composition of the magmas will be similar to those of the mafic volcanic units of the greenstone belt. If so, the high $\delta^{11} \mathrm{~B}$ value of $+10 \%$ for magmatic-derived fluid is consistent with the partitioning of boron to the fluid phase and isotopic fractionation between melt and fluid, whereby fluids are ${ }^{11} \mathrm{~B}$ enriched relative to the melt (Hervig et al. 1997; London 1997; Jiang and Palmer 1998). The magnitude of this fractionation depends on the temperature of fluid exsolution and the proportion of tetrahedral- vs. trigonalcoordinated boron in the melt. These factors are unknown for the Hira Buddini but a rough estimate based on melt-fluid experiments of peraluminous granite by Hervig et al. (2002) would predict an isotopic shift of 7\%o for a temperature of $700^{\circ} \mathrm{C}$, sufficient to explain the difference between the isotopically light (metamorphic) and heavy (magmatic) fluids.

The proposed scenario for variable $\delta^{11} \mathrm{~B}$ values of tourmaline from the Hira Buddini gold mine due to mixing of metamorphic and magmatic fluids is

Fig. 6 illustrated in Figure 6 and can be described as follows: After formation of the basaltic and intermediate volcanic rocks that now form the Hutti-Maski greenstone belt and their incorporation into the Dharwar craton, fluids were generated by devolatilization reactions under amphibolite grade conditions (Fig. 6a). These metamorphic fluids had moderate $\delta^{11} \mathrm{~B}$ values of about $+1 \%$ derived from the volcanic protoliths. The subsequent intrusion of I-type granitoids accompanied by magmatic degassing led to the formation of a second fluid system with comparably heavy boron isotopic composition of about $+10 \%$. At least locally, both of these fluids were present and able to mix in the early mineralization stage at Hira Buddini (tourmaline groups 2 and 3), but the magmatogenic fluid was dominant in the more intensely altered proximal zone 
(group 2 tourmaline). The younger tourmaline from metadacite (group 1), is also attributed to a magmatic-dominated fluid, which entered the hydrothermal system at a later stage preferentially in the distal and inner alteration zones, and the lower $\delta^{11} \mathrm{~B}$ values relative to group 2 are consistent with the greenschist grade of alteration (Fig. 6b).

\section{Conclusions}

Tourmaline is a widespread gangue mineral in alteration zones within metavolcanic rocks at the Hira Buddini gold mine in southern India. The tourmaline is compositionally intermediate between schorl and dravite and deviations from the ideal schorl-dravite mixing line can be explained by substitution reactions involving $\left(\mathrm{Fe}^{2+}, \mathrm{Fe}^{3+}\right)(\mathrm{Mg}, \mathrm{Al})_{-1}$ and $(\square, \mathrm{Al})(\mathrm{Na}, \mathrm{Mg})_{-1}$. Additional, minor-element variations like $\mathrm{Cr}$ enrichment are attributed to localscale compositional variations of the metabasaltic and metadacitic host rocks. Tourmaline $\delta^{11} \mathrm{~B}$ values vary in the range between $-4 \%$ and $+9 \%$, with rare outliers as low as $-13.3 \%$. The moderate to high $\delta^{11} \mathrm{~B}$ values of tourmaline from this deposit rule out a continental crustal source for boron in the hydrothermal system but are consistent with the postulated juvenile origin of greenstone-belt magmas and associated syn- to post-peak metamorphic I-type granitoids. The isotopic variability of tourmaline is associated with its occurrence in different alteration zones and can be explained by the existence of two isotopic different fluid phases, which penetrated the hydrothermal system at Hira Buddini along different access-paths and subsequently mixed. Calculated boron isotopic compositions of the fluids indicate both a metamorphic and a magmatic origin. Metamorphic hydrothermal phases most likely developed by devolatilization of 
greenstone lithologies during metamorphism of the volcanic sequences, leading to a fluid with relatively moderate $\delta^{11} \mathrm{~B}$ values of around $0 \%$, whereas a second fluid more enriched in ${ }^{11} \mathrm{~B}\left(\delta^{11} \mathrm{~B}\right.$ values around $+10 \%$ is attributed to magmatic fluids derived from degassing of I-type granitic plutons that intrude the greenstone belt.

\section{Acknowledgements}

Oona Appelt is acknowledged for her help during electron microprobe work and Ilona Schäpan provided assistance in the SIMS analyses. The authors would like to thank S.-Y. Jiang and an anonymous referee for their helpful comments on the manuscript. 


\section{References}

Barth S (1993) Boron isotope variations in nature: a synthesis. Geologische Rundschau 82: 640651.

Beckinsale R, Drury S, Holt R (1980) 3,360-Myr old gneisses from the South Indian Craton. Nature 238: 469-470.

Biswas SK (1990a) Gold mineralisation in Hutti-Maski greenstone belt, Karnataka, India. Indian Minerals 44: 1-14.

Biswas SK (1990b) Gold mineralisation in Uti Block of Hutti-Maski Supracrustal belt, Karnataka. Journal of the Geological Society of India 36: 79-89.

Burrows D, Spooner E (1987) Generation of magmatic H20-CO2 fluid enriched in Mo, Au and W within an Archean sodic granodiorite stock, Mink Lake, North Western Ontario. Economic Geology 82: 1931-1957.

Cantanzaro EJ, Champion C, Garner E, Marinenko G, Sappenfield K, Shields W (1970) Boric acid: isotopic and assay standard reference materials. National Bureau of Standards (US), Special Publication 260: 70.

Chadwick B, Vasudev VN, Ahmed N (1996) The Sandur Schist Belt and its adjacent plutonic rocks: Implications for late Archaean crustal evolution in Karnataka. Journal of the Geological Society of India 47: 37-57.

Chadwick B, Vasudev VN, Hedge GV (2000) The Dharwar craton, southern India, interpreted as the result of Late Archaean oblique convergence. Precambrian Res 99: 91-111.

Chakraborty S, Dingwell DB, Chaussidon M (1993) Chemical diffusivity of boron in melts of haplogranitic composition. Geochim Cosmochim Acta 57: 1741-1751.

Chardon D, Peucat J-J, Jayananada M, Choukroune P, Fanning CM (2002) Archean granitegreenstone tectonics at Kolar (South India): interplay of diapirism and bulk inhomogeneous contraction during juvenile magmatic accretion. Tectonics 21: 1-17.

Chaussidon M, Jambon A (1994) Boron content and isotopic composition of oceanic basalts: Geochemical and cosmochemical implications. Earth Plan Sci Lett 121: 277-291.

Dingwell DB, Pichavant M, Holtz F (1996) Experimental studies of boron in granitic melts. Reviews in Mineralogy 33: 331-385.

Dyar MD, Taylor ME, Lutz TM, Francis CA, Guidotti CV, Wise M (1998) Inclusive chemical characterization of tourmaline: Mössbauer study of Fe valence and site occupancy. Am Mineral 83: 848-864.

Dyar MD, Wiedenbeck M, Robertson D, Cross LR, Delany JS, Ferguson K, Francis CA, Grew ES, Guidotte CV, Hervig RL, Hughes JM, Husler J, Leeman WP, McGuire AV, Rhede D, Rothe H, Paul RL, Richards I, Yates M (2001) Reference minerals for microanalyses of light elements. Geostandard Newslett 25: 441-463.

Eilu P, Mathison C, Groves D, Allardyce W (1999) Atlas of alteration assemblages, styles and zoning in orogenic lode-gold deposits in a variety of host rock and metamorphic settings. Geology and Geophysics Department (Centre for Strategic Mineral Deposits) and University of Western Australia Extension. The University of Western Australia Publication, p 50. 
Friend C, Nutman A (1991) SHRIMP U-Pb geochronology of the Closepet Granite and Peninsular Gneiss, Karnataka, South India. Journal of the Geological Society of India 38.

Giritharan TS, Rajamani V (1998) Geochemistry of metavolcanics of the Hutti-Maski schist belt, South India: Implications to gold metallogeny in the Eastern Dharwar Craton. Journal of the Geological Society of India 51: 583-594.

Groves DI (1993) The crustal continuum model for late-Archaean lode-gold deposits of the Yilgarn Block, Western Australia. Mineralium Deposita 28: 366-374.

Groves DI, Phillips GN (1987) The genesis and tectonic control on Archaean gold deposits of the Western Australian shield: a metamorphic replacement model. Ore Geology Reviews 2: 287-322. Hawthorne FC, Henry DJ (1999) Classification of the minerals of the tourmaline group. Eur J Mineral 11: 201-215.

Hellmann A, Kolb J, Meyer MF (2005) Physikochemische Bedingungen während amphibolitfazieller hydrothermaler Goldmineralisation - Hira Buddinni, Indien. Berichte der Deutschen Mineralogischen Gesellschaft, Beih. z. Eur. J. Mineral. 17: 54.

Henry DJ, Dutrow BL (1996) Metamorphic tourmaline and its petrologic application. Reviews in Mineralogy 33: 502-558.

Henry DJ, Guidotti CV (1985) Tourmaline as a petrogenetic indicator mineral: an example from the staurolite-grade metapelites of NW Maine. Am Mineral 70: 1-15.

Hervig RL, London D, Morgan GB, Wolf MB (1997) Large boron isotope fractionation between hydrous vapor and silicate melt at igneous temperatures. 7th Annu VM Goldschmidt Conf, Lunar Planetary Inst, Houston, LPI Contribution, no 921: 93-94.

Hervig RL, Moore GM, Williams L, Peacock SM, Holloway JR, Roggensack K (2002) Isotopic and elemental partitioning between hydrous fluid and silicate melt. Am Mineral 87: 769-774. Jayananda M, Moyen J-F, Martin H, Peucat J-J, Auvray B, Mahabaleswar B (2000) Late Archaean (2550-2520 Ma) juvenile magmatism in the Eastern Dharwar craton, southern India: constraints from geochronology, Nd-Sr isotopes and whole rock geochemistry. Precambrian Res 99: 225-254. Jiang S-Y, Palmer MR (1998) Boron isotope systematics of tourmaline from granites and pegmatites: a synthesis. Eur J Mineral 10: 1253-1265.

Jiang S-Y, Palmer MR, Peng Q-M, Yang J-H (1997) Chemical and stable isotopic compositions of Proterozoic metamorphosed evaporites and associated tourmalines from the Houxianyu borate deposit, eastern Liaoning, China. Chem Geol 135: 189-211.

Jiang S-Y, Palmer MR, Slack JF, Shaw DR (1999) Boron isotope systematics of tourmaline formation in the Sullivan Pb-Zn-Ag deposit, British Columbia, Canada. Chem Geol 158: 131-144. Jiang S-Y, Palmer MR, Yeats CJ (2002) Chemical and boron isotopic compositions of tourmaline from the Archean Big Bell and Mount Gibson gold deposits, Murchison Province, Yilgarn Craton, Western Australia. Chem Geol 188: 229-247.

King R, Kerrich R (1989) Strontium isotope compositions of tourmaline from lode gold deposits of the Archean Abitibi greenstone belt (Ontario-Quebec, Canada): implications for source reservoirs. Chem Geol 79: 225-240. 
Kolb J, Rogers A, Meyer F (2005) Relative timing of deformation and two-stage gold mineralization at the Hutti Mine, Dharwar Craton, India. Mineralium Deposita 40: 156-174; DOI: 110.1007/s00126-00005-00475-y.

Kolb J, Rogers A, Meyer F, Vennemann T (2004) Development of fluid conduits in the auriferous shear zones of the Hutti Gold Mine, India: evidence for spatially and temporally heterogeneous fluid flow. Tectonophysics 378: 65-84; DOI: 10.1016/j.tecto.2003.1010.1009.

London D (1997) Estimating abundances of volatile and other mobile components in evolved silicic melts through mineral-melt equilibria. J Petrol 38: 1691-1706.

Manikyamba C, Naqvi S, Mohan M, Rao T (2004) Gold mineralisation and alteration of Penakacherla schist belt, India, constraints on Archaean subduction and fluid processes. Ore Geology Reviews 24: 199-227.

McCuaig T, Kerrich R (1998) P-T-t deformation fluid characteristics of lode-gold deposits: evidence from alteration systematics. Ore Geology Reviews 12: 381-453.

Meyer C, Wunder B, Meixner A, Romer R, Heinrich W (2007) Experimental study on the Bisotope fractionation between tourmaline and fluid: A re-investigation. Goldschmidt Conference Abstracts: A659.

Mishra B, Pal N, Sarbadhikari A (2005) Fluid inclusion characteristics of the Uti gold deposit, Hutti-Maski greenstone belt, southern India. Ore Geology Reviews 26: 1-16.

Morgan VI GB, London D (1989) Experimental reactions of amphibolite with boron-bearing aqueous fluids at $200 \mathrm{MPa}$ : implications for tourmaline stability and partial melting in mafic rocks. Contrib Mineral Petrol 102: 281-297.

Müller A, Groves D (1991) The classification of Western Australian greenstone-hosted gold deposits according to wallrock-alteration mineral assemblages. Ore Geology Reviews 6: 291-331. Nesbitt BE, Muehlenbachs K (1989) Geology, geochemistry and genesis of mesothermal lode gold deposits in the Canadian Cordillera: evidence for ore formation from evolved meteoric water. Econ Geol Monog 6: 501-509.

Pal N, Mishra B (2002) Alteration geochemistry and fluid inclusion characteristics of the greenstone-hosted gold deposit of Hutti, Eastern Dharwar Craton, India. Mineralium Deposita 37: 722-736; DOI: 710.1007/s00126-00002-00257-00128.

Palmer MR, London D, Morgan VI GB, Babb HA (1992) Experimental determination of fractionation of $11 \mathrm{~B} / 10 \mathrm{~B}$ between tourmaline and aqueous vapor: A temperature- and pressure dependent isotopic system. Chem Geol 101: 123-129.

Palmer MR, Slack JF (1989) Boron isotopic composition of tourmaline from massive sulfide deposits and tourmalinites. Contrib Mineral Petrol 103: 434-451.

Palmer MR, Swihart GH (1996) Boron isotope geochemistry: an overview In: Grew ES, Anovitz LM (eds) Boron: Mineralogy, Petrology and Geochemistry. Mineral. Soc. Am., Washington. Rev. Mineral. 33, pp 709-744.

Pichavant M (1983) Melt-fluid interaction deduced from studies of silicate-B2O3-H2O systems at 1 kbar. Bulletin of Mineralogy 106: 201-211.

Ridley J, Mikucki E, Groves D (1996) Archean lode-gold deposits: fluid flow and chemical evolution in vertically extensive hydrothermal systems. Ore Geology Reviews 10: 295-317. 
Rogers A, Kolb J, Meyer F, Armstrong R (2007) The tectono-magmatic evolution of the HuttiMaski Greenstone Belt, India: Constrained using geochemical and geochronological data. Journal of Asian Earth Sciences 31: 55-70; DOI: 10.1016/j.jseaes.2007.1004.1003.

Roy A (1979) Polyphase folding deformation in the Hutti-Maskischist belt, Karnataka. Journal of the Geological Society of India 20: 598-607.

Roy A (1991) The geology of gold mineralisation at Hutti in Hutti-Maski schist belt, Karnataka, India. Indian Minerals 45: 229-250.

Siddaiah N, Rajamani V (1989) The geologic setting, mineralogy, geochemistry and genesis of gold deposits of the Archean Kolar schist belt, India. Economic Geology 84: 2155-2172.

Slack JF (1996) Tourmaline associated with hydrothermal ore deposits In: Palmer MR, Swihart GH (eds) Boron isotope geochemistry: an overview. Mineralogical Society of America, Reviews in Mineralogy, pp 559-644.

Smith MP, Yardley BWD (1996) The boron isotopic comosition of tourmaline as a guide to fluid processes in the southwestern England orefield: An ion microprobe study. Geochim Cosmochim Acta 60: 1415-1427.

Spivack AJ, Berndt ME, Seyfried WEJ (1990) Boron isotope fractionation during supercritical phase separation. Geochim Cosmochim Acta 54: 2337-2339; DOI:2310.1016/00167037(2390)90060-X.

Srikantia S (1995) Geology of the Hutti-Maski Greenstone Belt In: Curtis L, Radhakrishna B (eds) Hutti Gold Mine into the 21st Century. Geological Society of India, pp 8-27.

Tonarini S, Forte C, Petrini R, Ferrara G (2003a) Melt/biotite 11B/10B isotopic fractionation and the boron local environment in the structure of volcanic glasses. Geochim Cosmochim Acta 67: 1863-1873.

Tonarini S, Pennisi M, Adorni-Braccesi A, Dini A, Ferrara G, Gonfiantini R, Wiedenbeck M, Gröning M (2003b) Intercomparison of Boron isotope and concentration measurements. Part I: Selection, preparation and homogeneity tests of the intercomparison materials. Geostandard Newslett 27: 21-39.

Vasudev VN, Chadwick B, Nutman AP, Hedge GV (2000) Rapid development of the Late Archaen Hutti schist belt, northern Karnataka: Implications of new field data and SHRIMP U/Pb zircon ages. Journal of the Geological Society of India 55: 529-540.

Wang LG, McNaughton NJ, Groves DI (1993) An overview of the relationship between granitoid intrusions and gold mineralization in the Archaean Murchisan Province, Western Australia. Mineralium Deposita 28: 482-494.

Wolf M, London D (1997) Boron in granitic magmas: stability of tourmaline in equilibrium with biotite and cordierite. Contrib Mineral Petrol 130: 12-30.

Wyman D, Kerrich R (1988) Alkaline magmatism, major structures and gold deposits: implications for greenstone belt metallogeny. Economic Geology 83: 454-461. 


\section{Figure captions}

Figure 1. (a) Location of the Hira Buddini gold mine in India, (b) Simplified geologic map of the Hutti-Maski greenstone belt, modified after Roy (1979) and Srikantia (1995).

Figure 2. Back-scattered electron (BSE) images of Hira Buddini tourmaline: (a) 25395: Weaklyaltered metabasalt. Magnesio-hornblende and plagioclase (oligoclase-andesine) with quartz and minor tourmaline. Tourmaline replaces actinolite and magnesio-hornblende, (b) 25386: Distal alteration zone in metabasalt, moderate alteration intensity, in gradation to the proximal alteration zone. Alteration assemblage includes actinolite, chlorite, titanite, K-feldspar, calcite, tourmaline and pyrite, (c, d, e) 25957 and 25962: Proximal zone within metabasalt; assemblage includes plagioclase (oligoclase - andesine), biotite and tourmaline after magnesio-hornblende, calcite, titanite, quartz, K-feldspar, (f) 25324: Distal alteration zone in metadacite; tourmaline is intergrown with calcite, quartz and pyrite; pyrite crack-fillings. Quartz shows undulose extinction and deformation lamellae, $(\mathrm{g}$ and $\mathrm{h})$ 25966: Greenschist facies, metadacite, deformed vein with assemblage: quartz + calcite + pyrite \pm albite and tourmaline. Note pyrite filling in cracks within quartz. Tourmaline locally surrounded by calcite, (i) 25577: Distal zone within metadacite. Greenschist facies with the alteration assemblage: muscovite + chlorite + pyrite + chalcopyrite + quartz + calcite \pm gold. Calcite and muscovite replace albite phenocrysts. Tourmaline occurs in veins intergrown with quartz and (j) 25965: Sigmoidal extensional quartz-albite vein in metadacite. The older quartz-albite-tourmaline vein assemblage is overprinted by calcitedominated veins and chlorite-hematite alteration.

Figure 3. (a) Ternary classification diagram showing the major tourmaline groups according to the principal constituent at the X-site (Hawthorne and Henry 1999), (b) Al-Fe-Mg ternary diagram after Henry and Guidotti (1985) with microprobe-determined compositions of tourmalines from the Hira Buddini gold mine. Labelled fields are: (1) Li-rich granitoid pegmatites and aplites, (2) Li-poor granitoids, pegmatites and aplites, (3) $\mathrm{Fe}^{3+}$-rich quartz-tourmaline rocks (altered granitoids), (4) metapelites and metapsammites with Al-saturating phase, (5) metapelites and metapsammites lacking Al-saturating phase, (6) $\mathrm{Fe}^{3+}$-rich quartz-tourmaline rocks, calc-silicate rocks and metapelites, (7) low-Ca metaultramafic rocks and Cr-V-rich metasediments, (8) metacarbonates and meta-pyroxenites.

Figure 4. Chemical composition of tourmaline expressed in terms of the atomic ratios $\mathrm{Fe} /(\mathrm{Fe}+\mathrm{Mg})$ versus (a) $\mathrm{Na} /\left(\mathrm{Na}+\mathrm{Ca}\right.$ ), (b) $\mathrm{F}$ (wt.\%) and (c) $\mathrm{Cr}_{2} \mathrm{O}_{3}$ (wt.\%); the inset shows composition of the metavolcanic hosts, (d) $\mathrm{Al}$ (atoms per formula unit) versus $\mathrm{X}$-site vacancies; exchenge vector arrows are indicated ( $\square$ - vacancy) (e) $\mathrm{Fe}$ (atoms p.f.u.) versus $\mathrm{X}$-site vacancies and (f) $\mathrm{Al}$ (atoms p.f.u.) versus $\mathrm{Fe}$ (atoms p.f.u.) of the Hira Buddini tourmaline. 
Figure 5. Frequency histograms of boron isotope composition of tourmaline from the Hira Buddini gold mine. External reproducibility of individual data is $2.4 \%$ ( $2 \sigma)$.

Figure 6. Schematic sketch of the Hira Buddini shear zone showing the influence of metamorphic and magmatic fluids on the formation of tourmaline and the preferential accessibilities of the fluid phases into the hydrothermal system: (a) First-stage tourmaline formation under amphibolitefacies conditions, and (b) second-stage tourmaline formation under greenschist-facies conditions. See text for details. The fractionation factors $(\alpha)$ between tourmaline and fluid are from Palmer et al. (1992). 


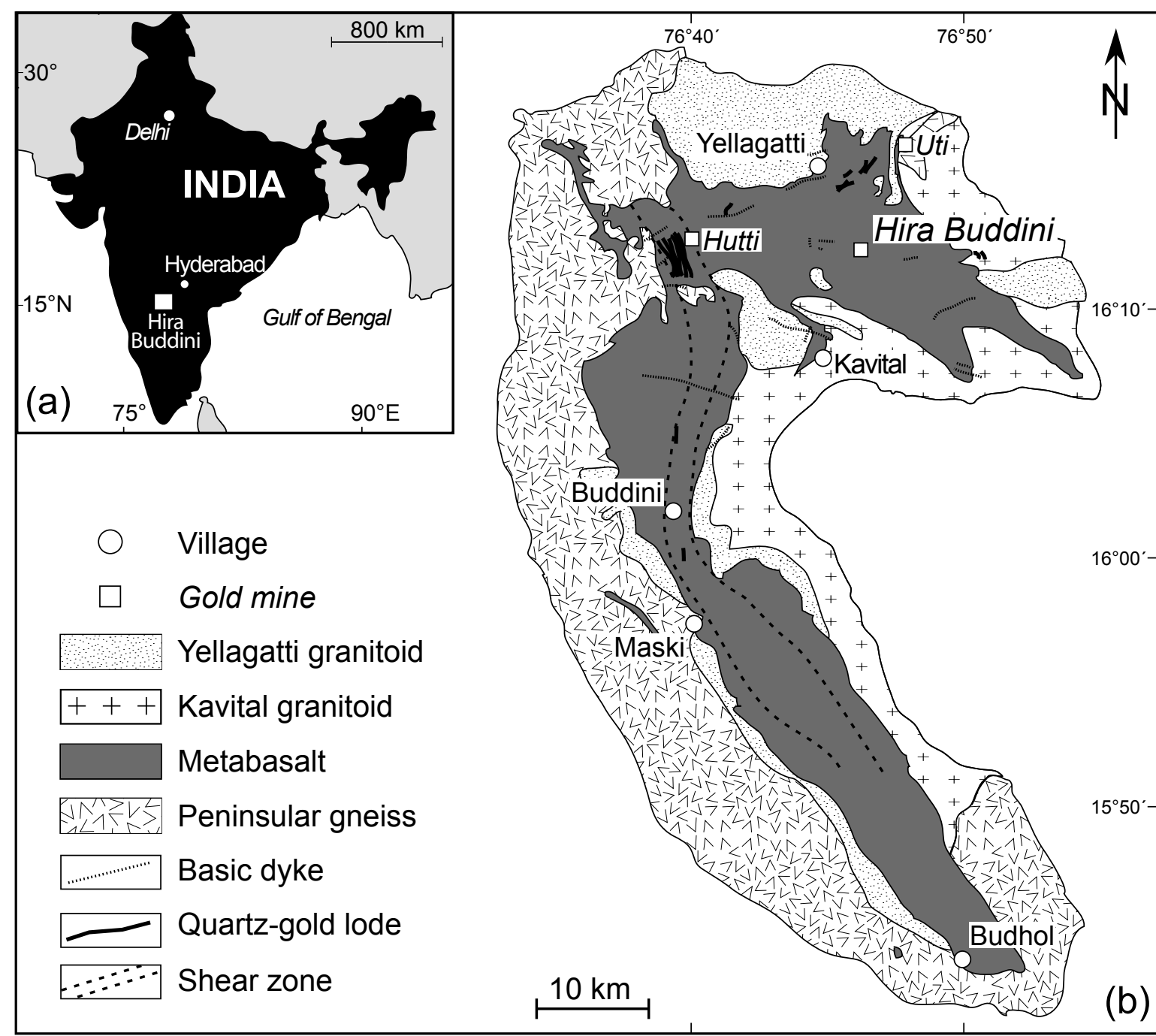

Krienitz et al. - Figure 1 

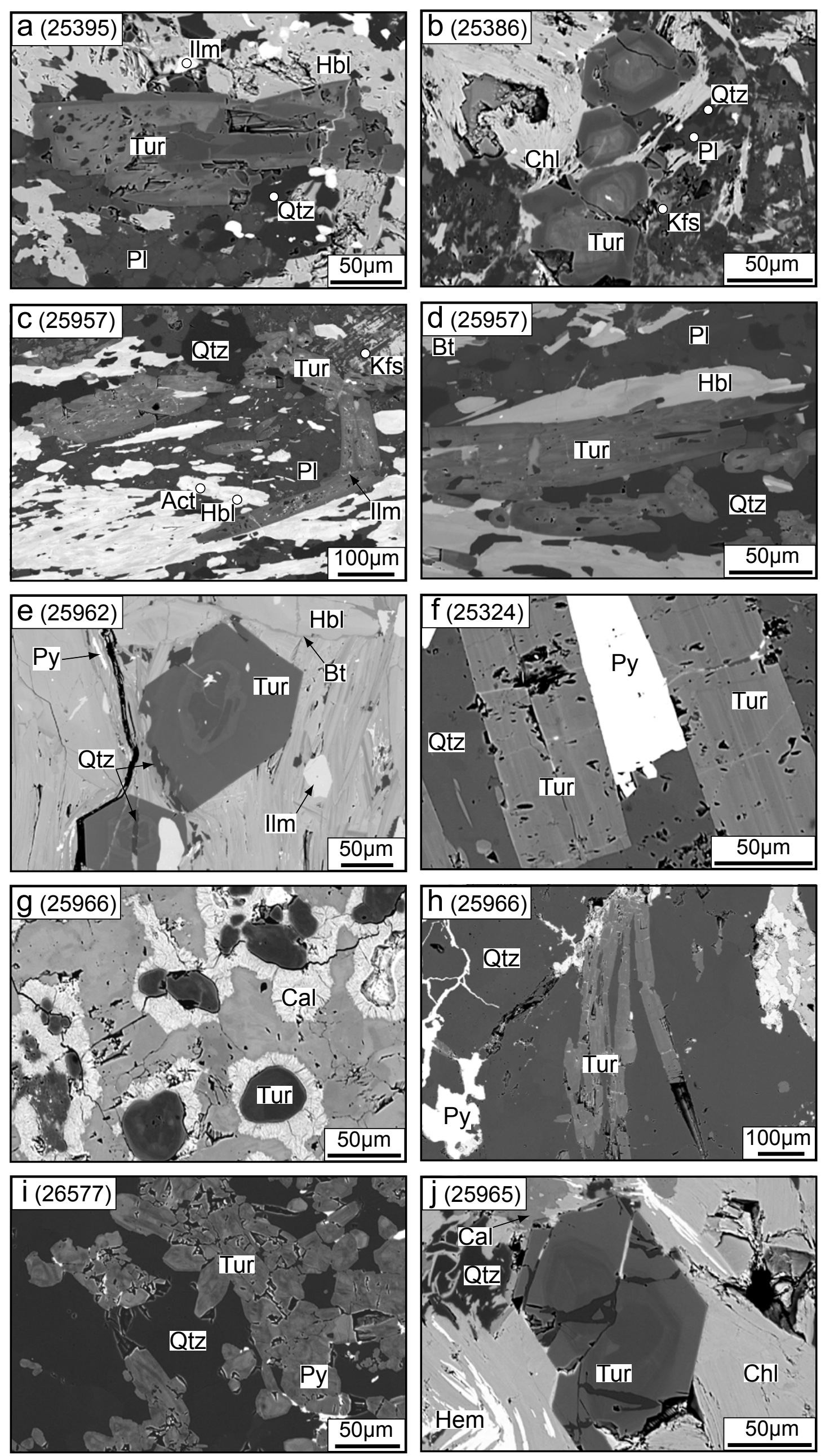

Krienitz et al. - Figure 2 

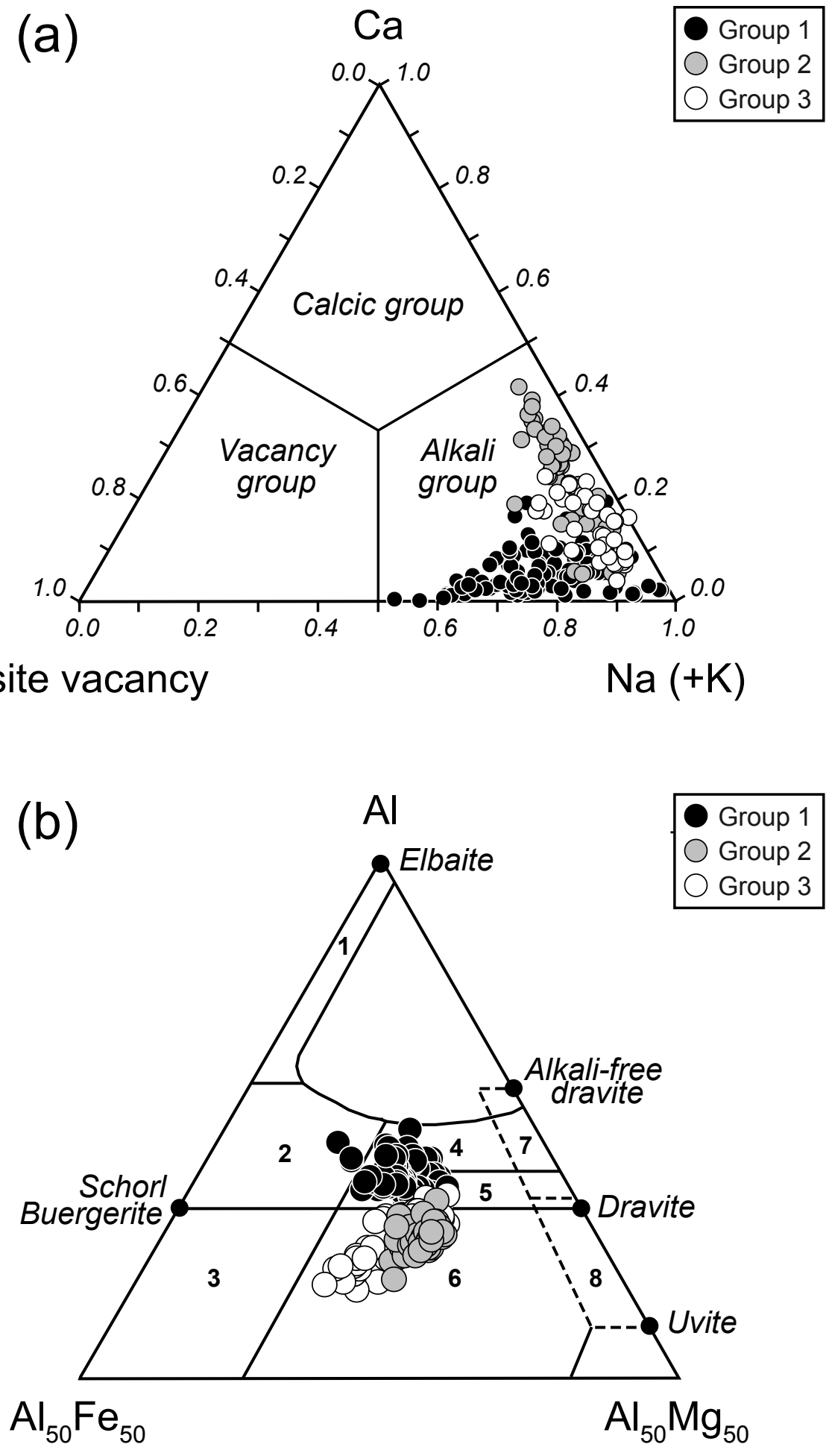

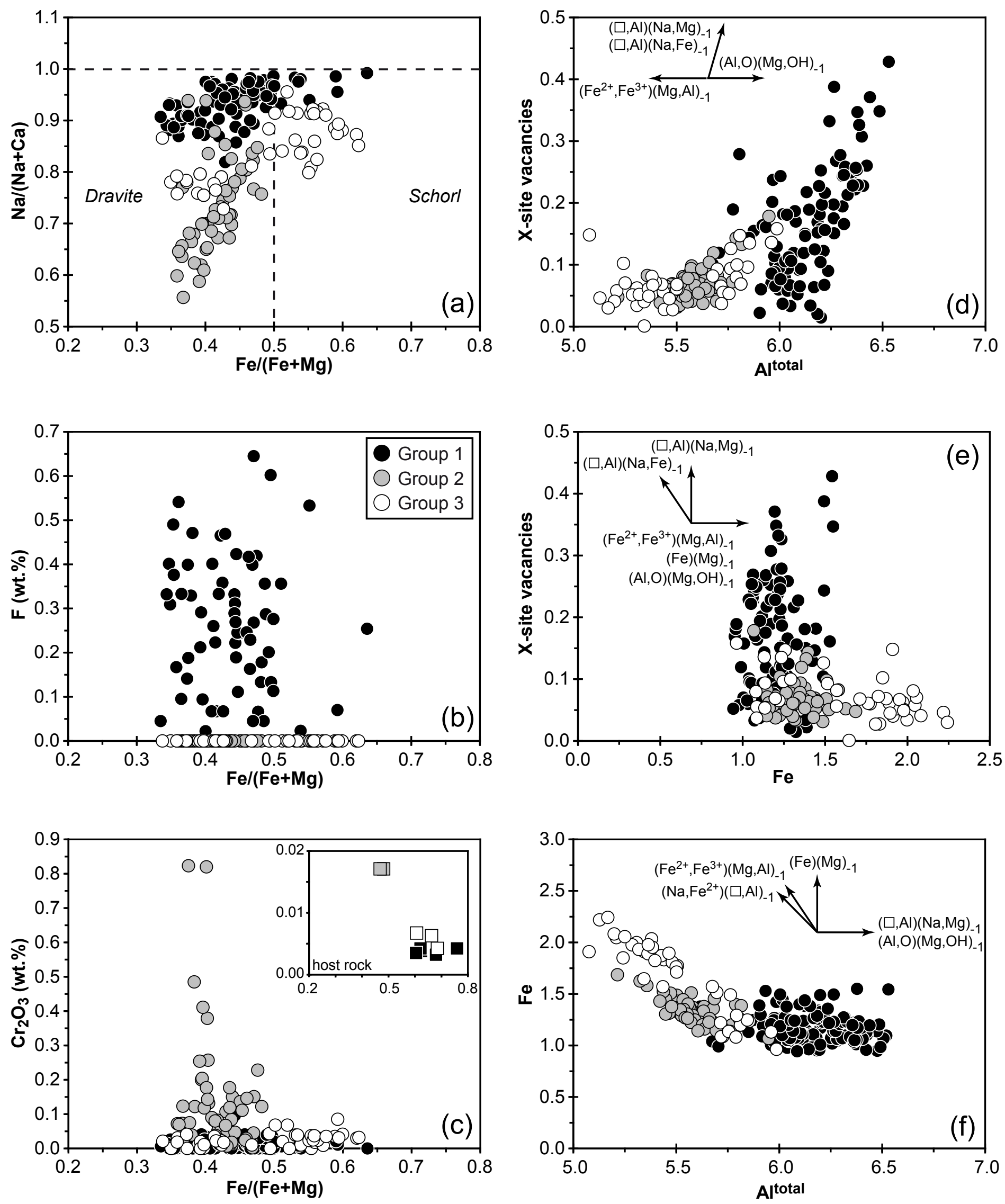


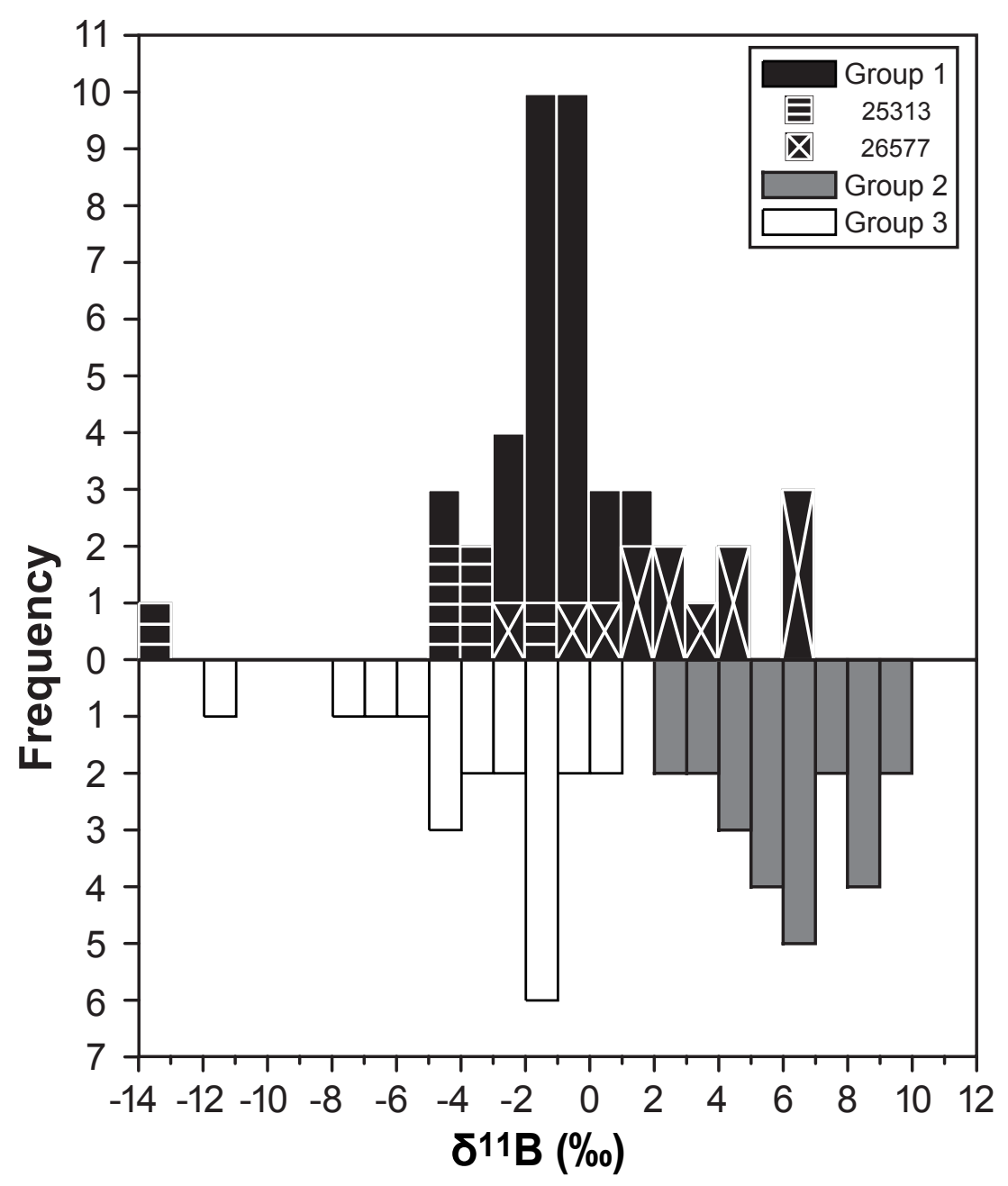

Krienitz et al. - Figure 5 


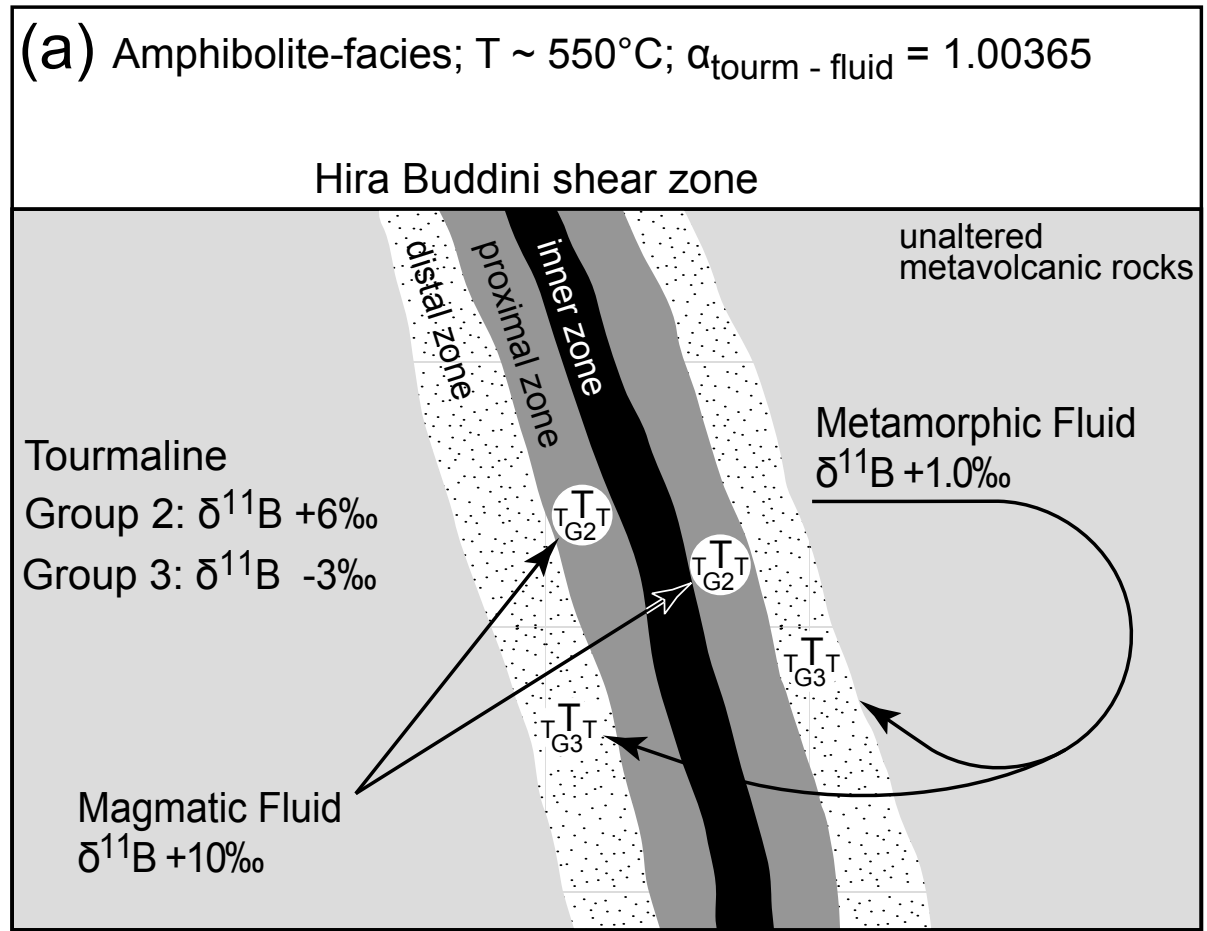

(b) Greenschist-facies; T $\sim 350^{\circ} \mathrm{C} ; \alpha_{\text {tourm - fluid }}=1.00655$

Hira Buddini shear zone

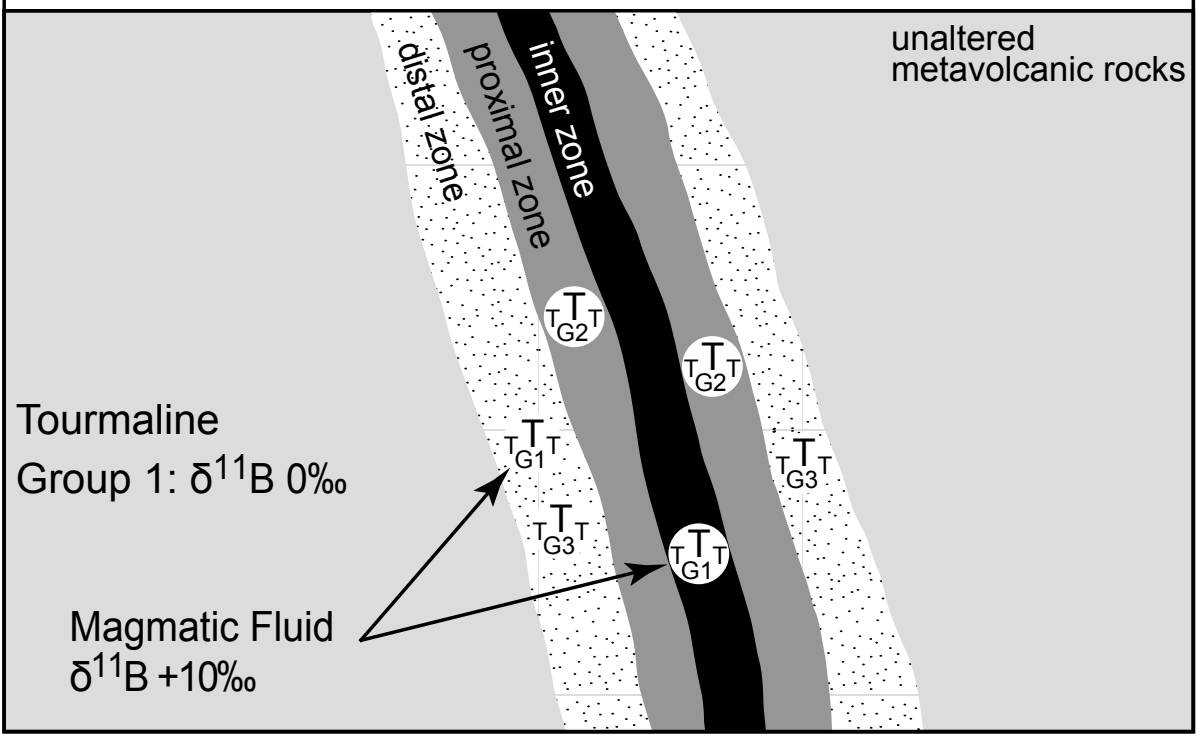


Table 1. Selected electron microprobe analyses and site assignments of tourmaline from the Hira Buddini gold mine.

\begin{tabular}{|c|c|c|c|c|c|c|c|c|c|c|c|c|c|c|c|c|c|c|c|c|}
\hline Sample & 25313 & & 25324 & & 25957 & & 25962 & & 25965 & & 25966 & & 25970 & & 26577 & & 25386 & & 25395 & \\
\hline $\mathrm{SiO}_{2}$ (wt.\%) & 36.10 & 35.38 & 37.39 & 37.03 & 36.19 & 36.42 & 36.05 & 36.89 & 36.28 & 37.00 & 37.01 & 37.40 & 36.94 & 35.57 & 36.53 & 35.67 & 36.49 & 35.84 & 36.12 & 35.41 \\
\hline $\mathrm{TiO}_{2}$ & 0.38 & 1.09 & 0.39 & 0.63 & 0.84 & 1.02 & 1.04 & 0.21 & 1.04 & 0.51 & 0.62 & 0.14 & 0.48 & 1.22 & 0.73 & 0.28 & 0.37 & 0.32 & 0.74 & 0.50 \\
\hline $\mathrm{Al}_{2} \mathrm{O}_{3}$ & 32.65 & 30.41 & 32.44 & 31.87 & 28.41 & 27.81 & 27.41 & 28.70 & 30.66 & 31.65 & 32.88 & 33.59 & 29.57 & 26.79 & 31.14 & 31.47 & 30.19 & 27.26 & 25.86 & 26.53 \\
\hline MgO & 6.34 & 7.12 & 6.97 & 7.25 & 7.13 & 7.59 & 7.81 & 7.62 & 6.42 & 7.71 & 6.05 & 5.23 & 7.81 & 6.19 & 6.27 & 5.48 & 7.02 & 5.92 & 5.36 & 5.55 \\
\hline MnO & 0.03 & 0.01 & 0.01 & 0.00 & 0.03 & 0.00 & 0.02 & 0.03 & 0.01 & 0.00 & 0.00 & 0.00 & 0.00 & 0.10 & 0.05 & 0.03 & 0.00 & 0.06 & 0.03 & 0.04 \\
\hline $\mathrm{FeO}^{\mathrm{a}}$ & 7.72 & 8.94 & 7.44 & 7.89 & 9.79 & 9.73 & 9.38 & 8.14 & 9.08 & 6.91 & 9.06 & 8.78 & 7.78 & 13.52 & 8.95 & 9.65 & 8.08 & 13.33 & 14.27 & 14.15 \\
\hline $\mathrm{CaO}$ & 0.30 & 0.94 & 0.31 & 0.51 & 1.27 & 1.71 & 1.59 & 0.31 & 0.33 & 0.50 & 0.31 & 0.08 & 1.08 & 1.06 & 0.65 & 0.16 & 0.98 & 0.45 & 0.60 & 0.57 \\
\hline $\mathrm{Na}_{2} \mathrm{O}$ & 1.96 & 1.97 & 2.50 & 2.59 & 2.15 & 1.94 & 2.05 & 2.63 & 2.62 & 2.70 & 2.39 & 1.95 & 2.26 & 2.33 & 2.17 & 2.70 & 2.12 & 2.63 & 2.44 & 2.42 \\
\hline $\mathrm{K}_{2} \mathrm{O}$ & 0.01 & 0.04 & 0.02 & 0.03 & 0.02 & 0.02 & 0.02 & 0.02 & 0.02 & 0.03 & 0.01 & 0.00 & 0.00 & 0.02 & 0.02 & 0.00 & 0.00 & 0.02 & 0.03 & 0.03 \\
\hline$F$ & 0.16 & 0.00 & 0.40 & 0.33 & 0.00 & 0.00 & 0.00 & 0.00 & 0.33 & 0.05 & 0.00 & 0.05 & 0.00 & 0.00 & 0.19 & 0.00 & 0.00 & 0.00 & 0.00 & 0.00 \\
\hline $\mathrm{Cl}$ & & & 0.00 & 0.00 & 0.01 & 0.00 & 0.00 & 0.00 & 0.04 & 0.01 & 0.00 & 0.00 & 0.01 & 0.00 & 0.01 & 0.01 & 0.00 & 0.00 & 0.01 & 0.01 \\
\hline $\mathrm{Cr}_{2} \mathrm{O}_{3}$ & 0.04 & 0.01 & 0.00 & 0.02 & 0.12 & 0.06 & 0.38 & 0.82 & 0.04 & 0.01 & 0.03 & 0.03 & 0.02 & 0.02 & 0.03 & 0.04 & 0.02 & 0.04 & 0.04 & 0.04 \\
\hline Sum & 85.69 & 85.91 & 87.86 & 88.15 & 85.95 & 86.30 & 85.75 & 85.37 & 86.87 & 87.07 & 88.35 & 87.25 & 85.94 & 86.82 & 86.72 & 85.50 & 85.26 & 85.87 & 85.49 & 85.24 \\
\hline$O=F$ & & & -0.17 & -0.14 & 0.00 & 0.00 & 0.00 & 0.00 & -0.14 & -0.02 & 0.00 & -0.02 & 0.00 & 0.00 & -0.08 & 0.00 & 0.00 & 0.00 & 0.00 & 0.00 \\
\hline Total & 85.62 & 85.91 & 87.70 & 88.02 & 85.94 & 86.30 & 85.75 & 85.37 & 86.72 & 87.05 & 88.35 & 87.23 & 85.94 & 86.82 & 86.64 & 85.50 & 85.26 & 85.87 & 85.49 & 85.24 \\
\hline Si (Atoms p.f.u.) ${ }^{b}$ & 5.963 & 5.887 & 6.060 & 6.006 & 6.090 & 6.109 & 6.100 & 6.212 & 6.022 & 6.035 & 5.980 & 6.082 & 6.136 & 6.016 & 6.044 & 5.995 & 6.111 & 6.092 & 6.220 & 6.091 \\
\hline $\operatorname{Al}(T)$ & 0.037 & 0.113 & 0.000 & 0.000 & 0.000 & 0.000 & 0.000 & 0.000 & 0.000 & 0.000 & 0.020 & 0.000 & 0.000 & 0.000 & 0.000 & 0.005 & 0.000 & 0.000 & 0.000 & 0.000 \\
\hline $\operatorname{Al}(\mathrm{Z})$ & 6.000 & 5.852 & 6.000 & 6.000 & 5.635 & 5.499 & 5.468 & 5.697 & 5.998 & 6.000 & 6.000 & 6.000 & 5.790 & 5.343 & 6.000 & 6.000 & 5.961 & 5.464 & 5.250 & 5.380 \\
\hline $\operatorname{Al}(Y)$ & 0.321 & 0.000 & 0.199 & 0.094 & 0.000 & 0.000 & 0.000 & 0.000 & 0.000 & 0.087 & 0.242 & 0.439 & 0.000 & 0.000 & 0.074 & 0.230 & 0.000 & 0.000 & 0.000 & 0.000 \\
\hline $\mathrm{Ti}$ & 0.047 & 0.136 & 0.047 & 0.076 & 0.107 & 0.129 & 0.132 & 0.027 & 0.129 & 0.062 & 0.076 & 0.017 & 0.060 & 0.155 & 0.091 & 0.036 & 0.046 & 0.041 & 0.096 & 0.065 \\
\hline $\mathbf{M g}$ & 1.561 & 1.766 & 1.684 & 1.753 & 1.787 & 1.898 & 1.970 & 1.912 & 1.589 & 1.873 & 1.457 & 1.268 & 1.934 & 1.560 & 1.546 & 1.373 & 1.751 & 1.500 & 1.374 & 1.423 \\
\hline Mn & 0.004 & 0.001 & 0.002 & 0.000 & 0.004 & 0.000 & 0.003 & 0.005 & 0.002 & 0.000 & 0.000 & 0.000 & 0.000 & 0.014 & 0.006 & 0.004 & 0.000 & 0.008 & 0.005 & 0.006 \\
\hline $\mathrm{Fe}$ & 1.066 & 1.244 & 1.008 & 1.071 & 1.377 & 1.365 & 1.327 & 1.147 & 1.260 & 0.943 & 1.225 & 1.194 & 1.081 & 1.912 & 1.239 & 1.356 & 1.131 & 1.895 & 2.055 & 2.035 \\
\hline $\mathrm{Ca}$ & 0.053 & 0.168 & 0.054 & 0.089 & 0.230 & 0.307 & 0.289 & 0.056 & 0.058 & 0.088 & 0.053 & 0.014 & 0.191 & 0.192 & 0.116 & 0.029 & 0.176 & 0.083 & 0.110 & 0.105 \\
\hline $\mathrm{Na}$ & 0.628 & 0.636 & 0.785 & 0.814 & 0.701 & 0.631 & 0.674 & 0.858 & 0.842 & 0.855 & 0.748 & 0.615 & 0.728 & 0.763 & 0.695 & 0.881 & 0.688 & 0.868 & 0.814 & 0.807 \\
\hline K & 0.002 & 0.008 & 0.003 & 0.005 & 0.003 & 0.004 & 0.005 & 0.003 & 0.005 & 0.005 & 0.001 & 0.001 & 0.001 & 0.005 & 0.003 & 0.000 & 0.000 & 0.005 & 0.006 & 0.007 \\
\hline X-site vacancies & 0.317 & 0.188 & 0.157 & 0.092 & 0.066 & 0.058 & 0.032 & 0.083 & 0.095 & 0.052 & 0.197 & 0.371 & 0.080 & 0.040 & 0.187 & 0.090 & 0.136 & 0.045 & 0.070 & 0.081 \\
\hline
\end{tabular}

${ }^{\mathrm{b}}$ Tourmaline formulae calculated on the basis of 15 cations in $\mathrm{T}, \mathrm{Z}$ and $\mathrm{Y}$ sites (recommended by Henry and Dutrow, 1996) 
Table 2. Boron isotope composition (SIMS) of tourmaline from the Hira Buddini gold mine.

\begin{tabular}{|c|c|c|c|c|c|c|c|c|c|c|c|}
\hline Sample & Group $^{a}$ & Grain \# & ${ }^{11} \mathrm{~B} /{ }^{10} \mathrm{~B}$ & $\delta^{11} \mathrm{~B}(\%)$ & $1 \sigma(\%))^{b}$ & Sample & Group $^{a}$ & Grain \# & ${ }^{11} \mathrm{~B} /{ }^{10} \mathrm{~B}$ & $\delta^{11} \mathrm{~B}(\% 0)$ & $1 \sigma(\% 0)^{b}$ \\
\hline \multirow[t]{7}{*}{25313} & 1 & T1 & 4.026 & -4.4 & 0.52 & 25966 & 1 & $\mathrm{~T} 1$ & 4.035 & -2.2 & 0.42 \\
\hline & & $\mathrm{T} 2$ & 4.028 & -3.9 & 0.47 & & & T1 & 4.038 & -1.4 & 0.58 \\
\hline & & T3 & 4.028 & -3.9 & 0.60 & & & $\mathrm{~T} 2$ & 4.038 & -1.4 & 0.63 \\
\hline & & T4 & 4.025 & -4.6 & 0.55 & & & $\mathrm{~T} 2$ & 4.039 & -1.1 & 0.59 \\
\hline & & T5 & 4.038 & -1.3 & 0.50 & & & T3 & 4.041 & -0.6 & 0.49 \\
\hline & & T6 & 3.990 & -13.3 & 0.72 & & & T5 & 4.041 & -0.6 & 0.51 \\
\hline & & & & & & & & T6 & 4.045 & 0.4 & 0.45 \\
\hline \multirow[t]{9}{*}{25324} & 1 & $\mathrm{~T} 1$ & 4.040 & -0.9 & 0.53 & & & $\mathrm{T7}$ & 4.041 & -0.6 & 0.57 \\
\hline & & T2 & 4.042 & -0.3 & 0.56 & & & T8 & 4.050 & 1.5 & 0.58 \\
\hline & & T3 & 4.043 & -0.1 & 0.43 & & & & & & \\
\hline & & $\mathrm{T} 4$ & 4.034 & -2.4 & 0.58 & 25970 & 3 & $\mathrm{~T} 1$ & 4.016 & -6.8 & 0.62 \\
\hline & & T5 & 4.041 & -0.6 & 0.46 & & & T2 & 4.015 & -7.1 & 0.54 \\
\hline & & T6 & 4.039 & -1.1 & 0.52 & & & T4 & 4.036 & -1.9 & 0.64 \\
\hline & & $\mathrm{T7}$ & 4.038 & -1.4 & 0.55 & & & T5 & 4.025 & -4.5 & 0.70 \\
\hline & & T8 & 4.036 & -1.9 & 0.50 & & & T5 & 4.026 & -4.2 & 0.50 \\
\hline & & & & & & & & T6 & 4.034 & -2.4 & 0.72 \\
\hline \multirow[t]{9}{*}{25957} & 2 & $\mathrm{~T} 1$ & 4.077 & 8.2 & 0.43 & & & $\mathrm{T7}$ & 3.996 & -11.8 & 0.75 \\
\hline & & $\mathrm{T} 2$ & 4.075 & 7.7 & 0.67 & & & & & & \\
\hline & & T3 & 4.067 & 5.9 & 0.59 & 26577 & 1 & $\mathrm{~T} 1$ & 4.035 & -2.2 & 0.65 \\
\hline & & $\mathrm{T} 4$ & 4.080 & 9.0 & 0.52 & & & T2 & 4.062 & 4.6 & 0.51 \\
\hline & & T5 & 4.063 & 4.9 & 0.56 & & & T3 & 4.070 & 6.4 & 0.52 \\
\hline & & T6 & 4.079 & 8.8 & 0.46 & & & T4 & 4.049 & 1.2 & 0.44 \\
\hline & & $\mathrm{T7}$ & 4.070 & 6.4 & 0.49 & & & T5 & 4.050 & 1.5 & 0.57 \\
\hline & & T8 & 4.069 & 6.2 & 0.59 & & & T6 & 4.048 & 1.0 & 0.47 \\
\hline & & & & & & & & $\mathrm{T7}$ & 4.072 & 6.9 & 0.62 \\
\hline \multirow[t]{17}{*}{25962} & 2 & T7 & 4.064 & 5.1 & 0.61 & & & T8 & 4.060 & 4.1 & 0.56 \\
\hline & & T7 & 4.077 & 8.2 & 0.52 & & & T9 & 4.068 & 6.1 & 0.46 \\
\hline & & T8 & 4.067 & 5.9 & 0.61 & & & T10 & 4.054 & 2.6 & 0.59 \\
\hline & & T8 & 4.069 & 6.2 & 0.55 & & & $\mathrm{~T} 11$ & 4.042 & -0.5 & 0.55 \\
\hline & & T8 & 4.074 & 7.5 & 0.37 & & & $\mathrm{~T} 12$ & 4.053 & 2.3 & 0.52 \\
\hline & & T9 & 4.070 & 6.4 & 0.53 & & & T13 & 4.056 & 3.1 & 0.48 \\
\hline & & T10 & 4.079 & 8.8 & 0.50 & & & & & & \\
\hline & & T10 & 4.080 & 9.0 & 0.52 & 25386 & 3 & $\mathrm{~T} 1$ & 4.045 & 0.4 & 0.53 \\
\hline & & T11 & 4.065 & 5.4 & 0.56 & & & T1 & 4.040 & -0.9 & 0.53 \\
\hline & & T12 & 4.070 & 6.4 & 0.58 & & & T3 & 4.039 & -1.1 & 0.69 \\
\hline & & T13 & 4.061 & 4.3 & 0.55 & & & T3 & 4.044 & 0.2 & 0.53 \\
\hline & & T13 & 4.053 & 2.3 & 0.51 & & & T4 & 4.039 & -1.1 & 0.59 \\
\hline & & T14 & 4.052 & 2.0 & 0.48 & & & T5 & 4.038 & -1.4 & 0.62 \\
\hline & & T15 & 4.057 & 3.3 & 0.61 & & & T6 & 4.036 & -1.9 & 0.62 \\
\hline & & T16 & 4.057 & 3.3 & 0.45 & & & & & & \\
\hline & & T17 & 4.062 & 4.6 & 0.47 & 25395 & 3 & $\mathrm{~T} 1$ & 4.035 & -2.2 & 0.54 \\
\hline & & & & & & & & T2 & 4.028 & -4.0 & 0.64 \\
\hline \multirow[t]{8}{*}{25965} & 1 & T1 & 4.039 & -1.1 & 0.49 & & & T3 & 4.037 & -1.6 & 0.61 \\
\hline & & $\mathrm{T} 2$ & 4.026 & -4.2 & 0.40 & & & T4 & 4.043 & -0.1 & 0.53 \\
\hline & & T3 & 4.039 & -1.1 & 0.51 & & & T5 & 4.023 & -5.0 & 0.51 \\
\hline & & T4 & 4.040 & -0.9 & 0.49 & & & T6 & 4.029 & -3.7 & 0.55 \\
\hline & & T5 & 4.044 & 0.2 & 0.50 & & & T7 & 4.026 & -4.2 & 0.57 \\
\hline & & T6 & 4.042 & -0.3 & 0.58 & & & & & & \\
\hline & & $\mathrm{T7}$ & 4.038 & -1.4 & 0.54 & & & & & & \\
\hline & & т8 & 4.035 & -2.2 & 0.47 & & & & & & \\
\hline
\end{tabular}

\footnotetext{
${ }^{a}$ Classification depends on the occurrence of young and old tourmaline in different alteration zones: group 1 - second generation, metadacite host, inner and distal alteration zones group 2 - first generation, metabasaltic host, proximal alteration zone group 3 - first generation, metabasaltic host, distal alteration zone

${ }^{\mathrm{b}}$ Internal precision (1 standard deviation of mean, from 50 cycles)
} 


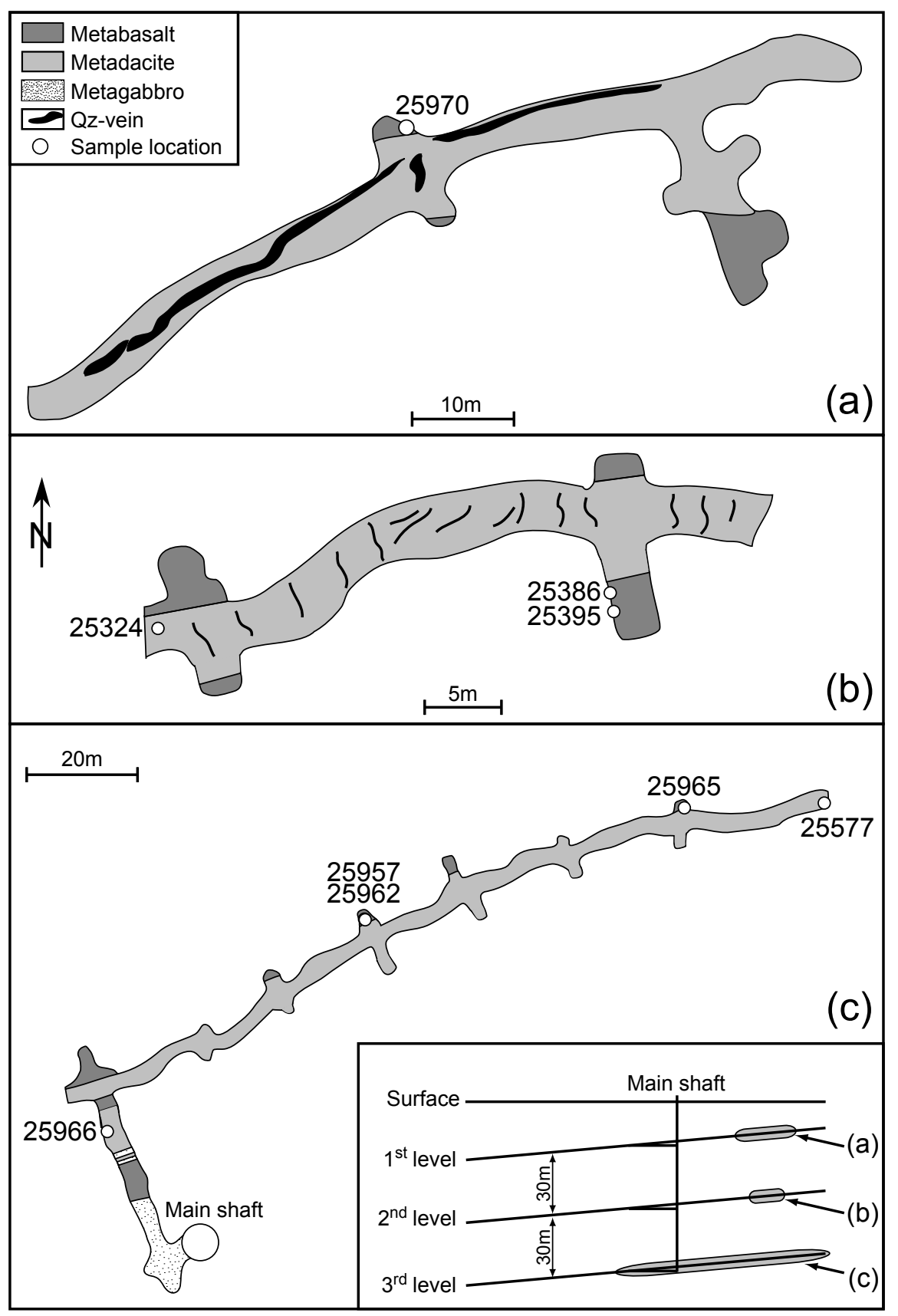

Krienitz et al. - ESM Figure 1 
Electronic Supplementary Material

Table 1. Location and sample description from the Hira Buddini gold mine.

$\begin{array}{lccccc}\text { Sample no. } & \text { Group } & \text { Alteration zone } & \text { Host rock } & \begin{array}{c}\text { Tourmaline } \\ \text { generation }\end{array} & \text { Tourmaline occurrence } \\ 25313 & 1 & \text { inner } & \text { Metadacite } & \text { young } & \text { selvage of quartz-calcite vein } \\ 25324 & 1 & \text { distal } & \text { Metadacite } & \text { young } & \text { quartz-calcite vein } \\ 25965 & 1 & \text { distal } & \text { Metadacite } & \text { young } & \text { quartz vein } \\ 25966 & 1 & \text { distal } & \text { Metadacite } & \text { young } & \text { quartz vein } \\ 26577 & 1 & \text { distal } & \text { Metadacite } & \text { young } & \text { monomineralic vein } \\ 25957 & 2 & \text { proximal } & \text { Metabasalt } & \text { old } & \text { wall rock } \\ 25962 & 2 & \text { proximal } & \text { Metabasalt } & \text { old } & \text { wall rock } \\ 25970 & 3 & \text { distal } & \text { Metabasalt } & \text { old } & \text { wall rock } \\ 25386 & 3 & \text { distal } & \text { Metabasalt } & \text { old } & \text { wall rock } \\ 25395 & 3 & \text { distal } & \text { Metabasalt } & \text { old } & \text { wall rock } \\ & & & & & \end{array}$

\footnotetext{
${ }^{a}$ Classification depends on the occurrence of young and old tourmaline in different alteration zones: group 1 - second generation, metadacite host, inner and distal alteration zones group 2 - first generation, metabasaltic host, proximal alteration zone group 3 - first generation, metabasaltic host, distal alteration zone
} 
Electronic Supplementary Material

Table 2. Electron microprobe analyses and site assignments of tourmaline from the Hira Buddini gold mine.

\begin{tabular}{|c|c|c|c|c|c|c|c|c|c|c|c|c|c|c|c|c|c|c|c|c|c|c|c|}
\hline Sample & 5313 & & & & & & & & & & & & & & & & & & & & & & \\
\hline $\mathrm{SiO}_{2}$ (wt.\%) & 36.09 & 36.80 & 36.83 & 36.64 & 36.89 & 36.93 & 36.62 & 35.72 & 35.73 & 35.99 & 36.30 & 35.68 & 35.83 & 36.26 & 35.49 & 35.55 & 35.96 & 36.40 & 36.12 & 35.49 & 35.47 & 35.74 & 36.10 \\
\hline $\mathrm{TiO}_{2}$ & 0.79 & 0.42 & 0.79 & 1.05 & 0.54 & 0.73 & 1.12 & 0.43 & 0.15 & 0.25 & 0.32 & 0.11 & 0.53 & 0.14 & 0.55 & 0.47 & 0.71 & 0.88 & 0.14 & 0.76 & 0.98 & 0.68 & 0.73 \\
\hline $\mathrm{Al}_{2} \mathrm{O}_{3}$ & 29.72 & 31.81 & 30.39 & 30.27 & 31.30 & 29.78 & 29.43 & 32.99 & 33.26 & 33.00 & 33.98 & 35.38 & 32.50 & 33.22 & 31.92 & 32.13 & 31.31 & 31.75 & 33.46 & 31.37 & 30.07 & 31.43 & 31.44 \\
\hline MgO & 6.90 & 6.04 & 6.80 & 6.25 & 6.17 & 7.14 & 7.30 & 6.13 & 6.73 & 6.88 & 5.91 & 5.76 & 7.14 & 6.78 & 6.37 & 7.26 & 6.55 & 7.07 & 5.89 & 7.04 & 7.39 & 7.25 & 7.23 \\
\hline MnO & 0.03 & 0.04 & 0.00 & 0.00 & 0.00 & 0.00 & 0.06 & 0.01 & 0.00 & 0.05 & 0.02 & 0.02 & 0.02 & 0.00 & 0.01 & 0.04 & 0.02 & 0.01 & 0.02 & 0.01 & 0.01 & 0.07 & 0.02 \\
\hline $\mathrm{FeO}^{\mathrm{a}}$ & 8.89 & 8.46 & 8.02 & 8.67 & 8.24 & 8.12 & 8.42 & 8.18 & 6.86 & 7.38 & 8.05 & 7.21 & 7.60 & 6.98 & 8.06 & 7.37 & 7.65 & 7.43 & 7.74 & 7.96 & 8.51 & 8.05 & 7.68 \\
\hline $\mathrm{CaO}$ & 0.61 & 0.20 & 0.57 & 0.33 & 0.24 & 0.60 & 0.93 & 0.19 & 0.20 & 0.24 & 0.09 & 0.04 & 0.51 & 0.20 & 0.41 & 0.39 & 0.47 & 0.74 & 0.08 & 0.47 & 1.07 & 0.56 & 0.50 \\
\hline $\mathrm{Na}_{2} \mathrm{O}$ & 2.25 & 2.20 & 2.14 & 2.15 & 2.28 & 2.31 & 1.99 & 2.17 & 1.90 & 1.90 & 1.90 & 1.65 & 2.13 & 1.98 & 2.08 & 2.14 & 2.00 & 2.13 & 1.89 & 2.41 & 1.99 & 2.03 & 2.29 \\
\hline $\mathrm{K}_{2} \mathrm{O}$ & 0.02 & 0.03 & 0.03 & 0.03 & 0.02 & 0.01 & 0.01 & 0.01 & 0.03 & 0.03 & 0.03 & 0.01 & 0.02 & 0.00 & 0.03 & 0.01 & 0.02 & 0.03 & 0.01 & 0.04 & 0.03 & 0.09 & 0.02 \\
\hline $\mathbf{F}$ & 0.00 & 0.00 & 0.00 & 0.00 & 0.00 & 0.00 & 0.00 & 0.18 & 0.00 & 0.00 & 0.13 & 0.13 & 0.31 & 0.00 & 0.11 & 0.20 & 0.00 & 0.05 & 0.11 & 0.13 & 0.22 & 0.07 & 0.24 \\
\hline $\mathrm{Cl}$ & 0.00 & 0.00 & 0.00 & 0.00 & 0.00 & 0.00 & 0.00 & & & & & & & & & & & & & & & & \\
\hline $\mathrm{Cr}_{2} \mathrm{O}_{3}$ & 0.04 & 0.02 & 0.03 & 0.00 & 0.03 & 0.00 & 0.00 & 0.02 & 0.00 & 0.00 & 0.02 & 0.00 & 0.00 & 0.00 & 0.03 & 0.00 & 0.03 & 0.06 & 0.04 & 0.00 & 0.04 & 0.05 & 0.00 \\
\hline Sum & 85.35 & 86.03 & 85.60 & 85.40 & 85.72 & 85.62 & 85.87 & 86.03 & 84.86 & 85.72 & 86.75 & 85.99 & 86.59 & 85.56 & 85.06 & 85.56 & 84.72 & 86.55 & 85.50 & 85.68 & 85.78 & 86.02 & 86.25 \\
\hline $\mathrm{O}=\mathrm{F}$ & 0.00 & 0.00 & 0.00 & 0.00 & 0.00 & 0.00 & 0.00 & & & & & & & & & & & & & & & & \\
\hline Total & 85.35 & 86.03 & 85.60 & 85.40 & 85.72 & 85.62 & 85.87 & 85.95 & 84.86 & 85.72 & 86.70 & 85.94 & 86.46 & 85.56 & 85.01 & 85.48 & 84.72 & 86.53 & 85.45 & 85.63 & 85.69 & 85.99 & 86.15 \\
\hline Si (Ato & 6.051 & 6.084 & 6.132 & 6.129 & 6.128 & 6.154 & 6.095 & 5.893 & 5.901 & 5.897 & 5.908 & 5.811 & 5.870 & 5.946 & 5.930 & 5.873 & 6.021 & 5.983 & 5.958 & 5.902 & 5.925 & 5.898 & 5.955 \\
\hline $\mathrm{Al}(\mathrm{T})$ & 0.000 & 0.000 & 0.000 & 0.000 & 0.000 & 0.000 & 0.000 & 0.107 & 0.099 & 0.103 & 0.092 & 0.189 & 0.130 & 0.054 & 0.070 & 0.127 & 0.000 & 0.017 & 0.042 & 0.098 & 0.075 & 0.102 & 0.045 \\
\hline $\mathrm{Al}(\mathrm{Z})$ & 5.875 & 6.000 & 5.965 & 5.968 & 6.000 & 5.851 & 5.774 & 6.000 & 6.000 & 6.000 & 6.000 & 6.000 & 6.000 & 6.000 & 6.000 & 6.000 & 6.000 & 6.000 & 6.000 & 6.000 & 5.847 & 6.000 & 6.000 \\
\hline $\mathrm{Al}(\mathrm{Y})$ & 0.000 & 0.200 & 0.000 & 0.000 & 0.131 & 0.000 & 0.000 & 0.309 & 0.377 & 0.271 & 0.429 & 0.604 & 0.147 & 0.368 & 0.217 & 0.130 & 0.181 & 0.136 & 0.464 & 0.052 & 0.000 & 0.012 & 0.070 \\
\hline $\mathrm{Ti}$ & 0.100 & 0.052 & 0.099 & 0.132 & 0.067 & 0.092 & 0.140 & 0.053 & 0.019 & 0.031 & 0.039 & 0.013 & 0.065 & 0.017 & 0.069 & 0.058 & 0.089 & 0.109 & 0.017 & 0.095 & 0.123 & 0.084 & 0.091 \\
\hline Mg & 1.724 & 1.489 & 1.687 & 1.559 & 1.527 & 1.772 & 1.811 & 1.507 & 1.657 & 1.680 & 1.434 & 1.398 & 1.743 & 1.657 & 1.586 & 1.787 & 1.635 & 1.732 & 1.448 & 1.745 & 1.840 & 1.783 & 1.777 \\
\hline Mn & 0.004 & 0.005 & 0.000 & 0.000 & 0.000 & 0.000 & 0.008 & 0.001 & 0.000 & 0.007 & 0.003 & 0.003 & 0.003 & 0.000 & 0.001 & 0.006 & 0.003 & 0.001 & 0.003 & 0.001 & 0.001 & 0.010 & 0.003 \\
\hline $\mathrm{Fe}$ & 1.247 & 1.169 & 1.117 & 1.213 & 1.145 & 1.131 & 1.172 & 1.129 & 0.948 & 1.011 & 1.096 & 0.982 & 1.041 & 0.957 & 1.126 & 1.018 & 1.071 & 1.021 & 1.068 & 1.107 & 1.189 & 1.111 & 1.060 \\
\hline $\mathrm{Ca}$ & 0.110 & 0.036 & 0.102 & 0.059 & 0.043 & 0.107 & 0.166 & 0.034 & 0.035 & 0.042 & 0.016 & 0.007 & 0.090 & 0.035 & 0.073 & 0.069 & 0.084 & 0.130 & 0.014 & 0.084 & 0.192 & 0.099 & 0.088 \\
\hline $\mathrm{Na}$ & 0.731 & 0.705 & 0.691 & 0.697 & 0.736 & 0.748 & 0.643 & 0.694 & 0.608 & 0.604 & 0.600 & 0.521 & 0.677 & 0.630 & 0.674 & 0.685 & 0.649 & 0.679 & 0.604 & 0.777 & 0.645 & 0.650 & 0.732 \\
\hline $\mathrm{K}$ & 0.004 & 0.006 & 0.005 & 0.006 & 0.004 & 0.002 & 0.003 & 0.002 & 0.006 & 0.006 & 0.006 & 0.002 & 0.004 & 0.000 & 0.006 & 0.002 & 0.004 & 0.006 & 0.002 & 0.008 & 0.006 & 0.019 & 0.004 \\
\hline X-site vacancies & 0.155 & 0.252 & 0.202 & 0.237 & 0.217 & 0.143 & 0.189 & 0.270 & 0.350 & 0.348 & 0.378 & 0.470 & 0.230 & 0.335 & 0.246 & 0.243 & 0.262 & 0.184 & 0.379 & 0.131 & 0.158 & 0.233 & 0.175 \\
\hline
\end{tabular}

${ }^{a}$ Total Fe as FeO

${ }^{\mathrm{b}}$ Tourmaline formulae calculated on the basis of 15 cations in $T, Z$ and $Y$ sites (recommended by Henry and Dutrow, 1996) 


\begin{tabular}{|c|c|c|c|c|c|c|c|c|c|c|c|c|c|c|c|c|c|c|c|c|c|c|}
\hline Sample & 25313 & & & & & & & 25324 & & & & & & & & & & & & & & \\
\hline $\mathrm{SiO}_{2}$ (wt.\%) & 35.19 & 35.68 & 35.91 & 35.63 & 36.14 & 35.91 & 35.25 & 37.52 & 37.49 & 36.82 & 37.01 & 39.26 & 37.24 & 39.57 & 36.97 & 37.14 & 40.59 & 36.41 & 37.05 & 36.75 & 36.88 & 37.61 \\
\hline $\mathrm{TiO}_{2}$ & 0.88 & 0.59 & 0.92 & & 0.16 & 0.55 & 1.19 & 0.33 & 0.34 & 0.77 & 0.69 & 0.72 & 0.72 & 0.53 & 0.76 & 0.70 & 0.58 & 0.59 & 0.59 & 0.53 & 0.52 & 0.27 \\
\hline $\mathrm{Al}_{2} \mathrm{O}_{3}$ & 32.13 & 31.52 & 31.80 & 33.33 & 33.87 & 33.29 & 28.22 & 32.57 & 32.37 & 30.70 & 31.43 & 29.70 & 31.66 & 31.16 & 31.49 & 31.84 & 30.15 & 30.97 & 31.64 & 31.25 & 31.82 & 32.43 \\
\hline MgO & 7.12 & 7.00 & 7.44 & 6.19 & 6.71 & 6.26 & 7.57 & 7.42 & 7.11 & 7.65 & 7.85 & 7.61 & 7.74 & 6.47 & 7.37 & 7.68 & 7.20 & 7.39 & 7.59 & 7.07 & 7.48 & 7.56 \\
\hline MnO & 0.05 & 0.02 & 0.04 & 0.00 & 0.02 & 0.00 & 0.00 & 0.00 & 0.00 & 0.00 & 0.02 & 0.00 & 0.04 & 0.02 & 0.01 & 0.00 & 0.00 & 0.02 & 0.05 & 0.01 & 0.00 & 0.04 \\
\hline $\mathrm{FeO}^{\mathrm{a}}$ & 7.77 & 7.98 & 8.11 & 8.25 & 7.24 & 8.05 & 9.76 & 7.07 & 7.05 & 7.30 & 7.64 & 7.66 & 7.22 & 8.07 & 8.10 & 7.74 & 7.38 & 8.63 & 7.77 & 8.15 & 7.94 & 7.16 \\
\hline $\mathrm{CaO}$ & 0.60 & 0.42 & 0.56 & 0.15 & 0.22 & 0.19 & 1.67 & 0.32 & 0.33 & 0.62 & 0.58 & 0.67 & 0.59 & 0.31 & 0.52 & 0.58 & 0.51 & 0.57 & 0.48 & 0.44 & 0.43 & 0.33 \\
\hline $\mathrm{Na}_{2} \mathrm{O}$ & 2.06 & 2.26 & 2.23 & 2.09 & 2.06 & 2.12 & 1.94 & 2.47 & 2.41 & 2.55 & 2.67 & 2.48 & 2.66 & 2.50 & 2.63 & 2.56 & 2.54 & 2.50 & 2.61 & 2.68 & 2.39 & 2.41 \\
\hline $\mathrm{K}_{2} \mathrm{O}$ & 0.03 & 0.01 & 0.03 & 0.02 & 0.02 & 0.03 & 0.03 & 0.02 & 0.01 & 0.02 & 0.02 & 0.01 & 0.03 & 0.01 & 0.02 & 0.03 & 0.02 & 0.02 & 0.02 & 0.01 & 0.02 & 0.02 \\
\hline$F$ & 0.36 & 0.00 & 0.04 & 0.07 & 0.13 & 0.22 & 0.09 & 0.00 & 0.17 & 0.31 & 0.49 & 0.00 & 0.33 & 0.26 & 0.47 & 0.54 & 0.33 & 0.09 & 0.10 & 0.21 & 0.14 & 0.40 \\
\hline $\mathrm{Cl}$ & & & & & & & & 0.01 & 0.01 & 0.00 & 0.00 & 0.00 & 0.01 & 0.01 & 0.01 & 0.00 & 0.00 & 0.00 & 0.01 & 0.02 & 0.00 & 0.00 \\
\hline $\mathrm{Cr}_{2} \mathrm{O}_{3}$ & 0.03 & 0.03 & 0.05 & 0.00 & 0.02 & 0.01 & 0.00 & 0.00 & 0.00 & 0.03 & 0.00 & 0.02 & 0.01 & 0.00 & 0.00 & 0.01 & 0.03 & 0.00 & 0.02 & 0.03 & 0.03 & 0.00 \\
\hline Sum & 86.22 & 85.51 & 87.13 & 93.98 & 86.59 & 86.63 & 85.72 & 87.72 & 87.30 & 86.77 & 88.39 & 88.13 & 88.24 & 88.91 & 88.33 & 88.81 & 89.33 & 87.17 & 87.91 & 87.15 & 87.64 & 88.23 \\
\hline$O=F$ & & & & & & & & 0.00 & -0.07 & -0.13 & -0.21 & 0.00 & -0.14 & -0.11 & -0.20 & -0.23 & -0.14 & -0.04 & -0.04 & -0.09 & -0.06 & -0.17 \\
\hline Total & 86.07 & 85.51 & 87.11 & 93.95 & 86.54 & 86.54 & 85.68 & 87.72 & 87.22 & 86.64 & 88.19 & 88.13 & 88.10 & 88.80 & 88.13 & 88.58 & 89.19 & 87.13 & 87.87 & 87.06 & 87.58 & 88.06 \\
\hline Si (Atoms p.f.u.) ${ }^{b}$ & 5.808 & 5.920 & 5.855 & 5.870 & 5.876 & 5.878 & 5.950 & 6.043 & 6.086 & 6.063 & 5.990 & 6.362 & 6.025 & 6.375 & 5.999 & 5.983 & 6.514 & 5.962 & 5.999 & 6.035 & 5.976 & 6.044 \\
\hline $\operatorname{Al}(T)$ & 0.192 & 0.080 & 0.145 & 0.130 & 0.124 & 0.122 & 0.050 & 0.000 & 0.000 & 0.000 & 0.010 & 0.000 & 0.000 & 0.000 & 0.001 & 0.017 & 0.000 & 0.038 & 0.001 & 0.000 & 0.024 & 0.000 \\
\hline $\operatorname{Al}(\mathrm{Z})$ & 6.000 & 6.000 & 5.968 & 6.000 & 6.000 & 6.000 & 5.567 & 6.000 & 6.000 & 5.960 & 5.985 & 5.674 & 6.000 & 5.918 & 6.000 & 6.000 & 5.705 & 5.941 & 6.000 & 6.000 & 6.000 & 6.000 \\
\hline $\mathrm{Al}(\mathrm{Y})$ & 0.060 & 0.085 & 0.000 & 0.343 & 0.367 & 0.303 & 0.000 & 0.184 & 0.195 & 0.000 & 0.000 & 0.000 & 0.039 & 0.000 & 0.025 & 0.029 & 0.000 & 0.000 & 0.039 & 0.050 & 0.055 & 0.143 \\
\hline $\mathrm{Ti}$ & 0.109 & 0.074 & 0.113 & 0.000 & 0.020 & 0.068 & 0.151 & 0.039 & 0.042 & 0.095 & 0.084 & 0.088 & 0.088 & 0.064 & 0.092 & 0.084 & 0.070 & 0.072 & 0.071 & 0.065 & 0.063 & 0.033 \\
\hline Mg & 1.751 & 1.731 & 1.808 & 1.520 & 1.626 & 1.527 & 1.904 & 1.782 & 1.720 & 1.877 & 1.894 & 1.838 & 1.866 & 1.553 & 1.783 & 1.844 & 1.721 & 1.803 & 1.831 & 1.731 & 1.806 & 1.811 \\
\hline Mn & 0.007 & 0.003 & 0.006 & 0.000 & 0.003 & 0.000 & 0.000 & 0.000 & 0.000 & 0.000 & 0.002 & 0.000 & 0.005 & 0.002 & 0.001 & 0.000 & 0.000 & 0.002 & 0.007 & 0.001 & 0.000 & 0.006 \\
\hline $\mathrm{Fe}$ & 1.073 & 1.107 & 1.106 & 1.137 & 0.984 & 1.102 & 1.378 & 0.952 & 0.958 & 1.005 & 1.034 & 1.038 & 0.977 & 1.088 & 1.099 & 1.042 & 0.990 & 1.182 & 1.052 & 1.119 & 1.076 & 0.962 \\
\hline $\mathrm{Ca}$ & 0.106 & 0.075 & 0.098 & 0.026 & 0.038 & 0.033 & 0.302 & 0.056 & 0.058 & 0.110 & 0.100 & 0.117 & 0.103 & 0.053 & 0.090 & 0.100 & 0.087 & 0.100 & 0.082 & 0.078 & 0.074 & 0.057 \\
\hline $\mathrm{Na}$ & 0.659 & 0.727 & 0.705 & 0.668 & 0.649 & 0.673 & 0.635 & 0.772 & 0.758 & 0.815 & 0.837 & 0.779 & 0.834 & 0.781 & 0.826 & 0.799 & 0.790 & 0.794 & 0.821 & 0.852 & 0.752 & 0.751 \\
\hline K & 0.006 & 0.002 & 0.006 & 0.004 & 0.004 & 0.006 & 0.006 & 0.003 & 0.003 & 0.005 & 0.003 & 0.003 & 0.005 & 0.003 & 0.004 & 0.005 & 0.004 & 0.004 & 0.003 & 0.003 & 0.004 & 0.004 \\
\hline X-site vacancies & 0.228 & 0.196 & 0.191 & 0.302 & 0.308 & 0.288 & 0.056 & 0.169 & 0.181 & 0.070 & 0.060 & 0.101 & 0.058 & 0.164 & 0.079 & 0.096 & 0.119 & 0.103 & 0.094 & 0.067 & 0.170 & 0.189 \\
\hline
\end{tabular}




\begin{tabular}{|c|c|c|c|c|c|c|c|c|c|c|c|c|c|c|c|c|c|c|c|c|c|c|}
\hline \multirow{2}{*}{$\frac{\text { Sample }}{\mathrm{SiO}_{2} \text { (wt.\%) }}$} & \multicolumn{3}{|l|}{25324} & \multicolumn{19}{|l|}{25957} \\
\hline & 37.18 & 36.44 & 36.89 & 36.29 & 36.24 & 36.12 & 36.19 & 36.18 & 36.27 & 36.28 & 36.46 & 36.31 & 36.27 & 36.08 & 36.55 & 36.19 & 36.40 & 36.30 & 36.20 & 36.42 & 36.94 & 36.68 \\
\hline $\mathrm{TiO}_{2}$ & 0.76 & 0.68 & 0.66 & 0.97 & 0.81 & 0.83 & 1.25 & 1.43 & 0.99 & 1.05 & 1.15 & 1.20 & 1.02 & 1.10 & 0.67 & 1.01 & 0.73 & 0.69 & 1.04 & 0.97 & 0.22 & 0.19 \\
\hline $\mathrm{Al}_{2} \mathrm{O}_{3}$ & 31.28 & 31.40 & 31.54 & 28.32 & 27.66 & 27.69 & 26.89 & 26.72 & 27.93 & 27.82 & 28.37 & 28.00 & 28.08 & 27.54 & 27.55 & 27.45 & 27.52 & 28.02 & 28.00 & 28.16 & 29.55 & 29.51 \\
\hline MgO & 7.75 & 6.84 & 7.35 & 7.45 & 7.35 & 7.22 & 7.07 & 6.94 & 7.39 & 7.35 & 7.36 & 7.44 & 7.31 & 7.33 & 7.05 & 7.50 & 7.36 & 6.78 & 7.31 & 7.38 & 6.65 & 6.60 \\
\hline MnO & 0.00 & 0.02 & 0.04 & 0.05 & 0.07 & 0.02 & 0.03 & 0.04 & 0.03 & 0.02 & 0.02 & 0.01 & 0.04 & 0.08 & 0.05 & 0.00 & 0.05 & 0.02 & 0.04 & 0.00 & 0.01 & 0.00 \\
\hline $\mathrm{FeO}^{\mathrm{a}}$ & 7.57 & 8.12 & 7.87 & 9.78 & 10.24 & 10.54 & 11.18 & 11.50 & 9.92 & 10.18 & 9.39 & 9.83 & 9.80 & 10.19 & 10.69 & 10.28 & 10.87 & 10.70 & 10.04 & 9.62 & 10.05 & 9.91 \\
\hline $\mathrm{CaO}$ & 0.61 & 0.41 & 0.50 & 1.48 & 1.20 & 1.13 & 1.18 & 1.26 & 1.48 & 1.47 & 1.46 & 1.30 & 1.41 & 1.54 & 1.01 & 1.69 & 1.02 & 0.88 & 1.45 & 1.35 & 0.33 & 0.31 \\
\hline $\mathrm{Na}_{2} \mathrm{O}$ & 2.62 & 2.60 & 2.77 & 2.05 & 2.20 & 2.32 & 2.14 & 2.18 & 2.04 & 2.05 & 2.05 & 2.10 & 2.01 & 1.97 & 2.28 & 1.91 & 2.33 & 2.26 & 2.03 & 2.03 & 2.46 & 2.51 \\
\hline $\mathrm{K}_{2} \mathrm{O}$ & 0.03 & 0.01 & 0.02 & 0.01 & 0.01 & 0.04 & 0.01 & 0.03 & 0.04 & 0.03 & 0.01 & 0.02 & 0.03 & 0.03 & 0.02 & 0.03 & 0.04 & 0.02 & 0.02 & 0.01 & 0.03 & 0.00 \\
\hline $\mathbf{F}$ & 0.38 & 0.00 & 0.19 & 0.00 & 0.00 & 0.00 & 0.00 & 0.00 & 0.00 & 0.00 & 0.00 & 0.00 & 0.00 & 0.00 & 0.00 & 0.00 & 0.00 & 0.00 & 0.00 & 0.00 & 0.00 & 0.00 \\
\hline $\mathrm{Cl}$ & 0.00 & 0.00 & 0.01 & 0.00 & 0.00 & 0.00 & 0.00 & 0.00 & 0.01 & 0.01 & 0.00 & 0.00 & 0.00 & 0.00 & 0.00 & 0.00 & 0.00 & 0.00 & 0.00 & 0.00 & 0.00 & 0.01 \\
\hline $\mathrm{Cr}_{2} \mathrm{O}_{3}$ & 0.00 & 0.04 & 0.02 & 0.02 & 0.15 & 0.14 & 0.15 & 0.12 & 0.11 & 0.08 & 0.08 & 0.05 & 0.03 & 0.01 & 0.15 & 0.18 & 0.11 & 0.05 & 0.01 & 0.06 & 0.03 & 0.02 \\
\hline Sum & 88.18 & 86.57 & 87.86 & 86.42 & 85.92 & 86.04 & 86.10 & 86.40 & 86.19 & 86.33 & 86.34 & 86.27 & 86.00 & 85.88 & 86.02 & 86.25 & 86.44 & 85.71 & 86.13 & 86.00 & 86.27 & 85.73 \\
\hline$O=F$ & -0.16 & 0.00 & -0.08 & 0.00 & 0.00 & 0.00 & 0.00 & 0.00 & 0.00 & 0.00 & 0.00 & 0.00 & 0.00 & 0.00 & 0.00 & 0.00 & 0.00 & 0.00 & 0.00 & 0.00 & 0.00 & 0.00 \\
\hline Total & 88.02 & 86.57 & 87.78 & 86.42 & 85.92 & 86.04 & 86.10 & 86.40 & 86.19 & 86.33 & 86.34 & 86.27 & 86.00 & 85.88 & 86.02 & 86.25 & 86.44 & 85.71 & 86.13 & 86.00 & 86.27 & 85.73 \\
\hline Si (Atoms p.f.u.) & 6.028 & 6.008 & 6.006 & 6.067 & 6.105 & 6.089 & 6.118 & 6.116 & 6.093 & 6.092 & 6.103 & 6.081 & 6.094 & 6.089 & 6.159 & 6.093 & 6.101 & 6.124 & 6.080 & 6.111 & 6.138 & 6.132 \\
\hline $\mathrm{Al}(\mathrm{T})$ & 0.000 & 0.000 & 0.000 & 0.000 & 0.000 & 0.000 & 0.000 & 0.000 & 0.000 & 0.000 & 0.000 & 0.000 & 0.000 & 0.000 & 0.000 & 0.000 & 0.000 & 0.000 & 0.000 & 0.000 & 0.000 & 0.000 \\
\hline $\mathrm{Al}(\mathrm{Z})$ & 5.979 & 6.000 & 6.000 & 5.581 & 5.494 & 5.503 & 5.357 & 5.324 & 5.532 & 5.506 & 5.599 & 5.530 & 5.563 & 5.479 & 5.473 & 5.449 & 5.437 & 5.573 & 5.544 & 5.571 & 5.789 & 5.816 \\
\hline $\mathrm{Al}(\mathrm{Y})$ & 0.000 & 0.103 & 0.052 & 0.000 & 0.000 & 0.000 & 0.000 & 0.000 & 0.000 & 0.000 & 0.000 & 0.000 & 0.000 & 0.000 & 0.000 & 0.000 & 0.000 & 0.000 & 0.000 & 0.000 & 0.000 & 0.000 \\
\hline Ti & 0.093 & 0.084 & 0.080 & 0.122 & 0.103 & 0.105 & 0.159 & 0.181 & 0.125 & 0.132 & 0.144 & 0.152 & 0.129 & 0.139 & 0.085 & 0.128 & 0.093 & 0.087 & 0.131 & 0.123 & 0.028 & 0.024 \\
\hline Mg & 1.874 & 1.681 & 1.784 & 1.855 & 1.844 & 1.814 & 1.780 & 1.748 & 1.852 & 1.838 & 1.836 & 1.858 & 1.832 & 1.844 & 1.769 & 1.882 & 1.838 & 1.704 & 1.830 & 1.845 & 1.648 & 1.644 \\
\hline Mn & 0.000 & 0.003 & 0.006 & 0.007 & 0.010 & 0.002 & 0.004 & 0.006 & 0.004 & 0.003 & 0.003 & 0.002 & 0.005 & 0.011 & 0.007 & 0.000 & 0.007 & 0.002 & 0.005 & 0.000 & 0.001 & 0.000 \\
\hline $\mathrm{Fe}$ & 1.027 & 1.120 & 1.072 & 1.368 & 1.443 & 1.486 & 1.581 & 1.625 & 1.394 & 1.429 & 1.314 & 1.377 & 1.377 & 1.438 & 1.507 & 1.448 & 1.523 & 1.509 & 1.410 & 1.350 & 1.397 & 1.386 \\
\hline $\mathrm{Ca}$ & 0.105 & 0.073 & 0.088 & 0.266 & 0.216 & 0.204 & 0.213 & 0.229 & 0.267 & 0.264 & 0.261 & 0.234 & 0.254 & 0.279 & 0.181 & 0.305 & 0.183 & 0.159 & 0.262 & 0.242 & 0.059 & 0.055 \\
\hline $\mathrm{Na}$ & 0.824 & 0.831 & 0.874 & 0.664 & 0.718 & 0.757 & 0.701 & 0.713 & 0.663 & 0.668 & 0.665 & 0.681 & 0.655 & 0.644 & 0.746 & 0.624 & 0.758 & 0.739 & 0.662 & 0.662 & 0.792 & 0.812 \\
\hline K & 0.006 & 0.003 & 0.005 & 0.002 & 0.003 & 0.008 & 0.003 & 0.006 & 0.009 & 0.006 & 0.002 & 0.004 & 0.005 & 0.007 & 0.005 & 0.006 & 0.009 & 0.003 & 0.004 & 0.003 & 0.006 & 0.000 \\
\hline X-site vacancies & 0.065 & 0.093 & 0.033 & 0.068 & 0.063 & 0.031 & 0.082 & 0.052 & 0.061 & 0.062 & 0.072 & 0.081 & 0.086 & 0.069 & 0.068 & 0.065 & 0.051 & 0.098 & 0.072 & 0.094 & 0.143 & 0.133 \\
\hline
\end{tabular}




\begin{tabular}{|c|c|c|c|c|c|c|c|c|c|c|c|c|c|c|c|c|c|c|c|c|c|c|}
\hline Sample & 25957 & & & & & & & 25962 & & & & & & & & & & & & & & \\
\hline $\mathrm{SiO}_{2}$ (wt.\%) & 36.40 & 36.29 & 36.37 & 36.84 & 36.01 & 36.43 & 36.60 & 35.92 & 35.89 & 36.14 & 36.55 & 36.52 & 36.38 & 35.92 & 35.98 & 35.95 & 36.09 & 36.84 & 36.69 & 35.95 & 36.32 & 36.32 \\
\hline $\mathrm{TiO}_{2}$ & 0.76 & 1.00 & 0.62 & 0.55 & 0.94 & 0.88 & 0.56 & 0.82 & 0.95 & 0.78 & 0.60 & 0.40 & 1.02 & 0.81 & 0.83 & 1.15 & 1.01 & 0.17 & 0.65 & 0.87 & 1.01 & 1.11 \\
\hline $\mathrm{Al}_{2} \mathrm{O}_{3}$ & 27.97 & 28.45 & 27.89 & 28.89 & 27.98 & 28.66 & 28.76 & 28.45 & 27.52 & 28.27 & 28.18 & 30.29 & 28.19 & 27.71 & 27.79 & 27.93 & 27.78 & 29.04 & 27.95 & 28.52 & 27.94 & 27.51 \\
\hline MgO & 7.26 & 7.42 & 7.24 & 7.01 & 7.37 & 7.43 & 6.60 & 7.55 & 7.68 & 7.82 & 7.61 & 7.42 & 7.59 & 7.74 & 7.99 & 7.68 & 7.46 & 7.13 & 7.62 & 7.61 & 7.75 & 7.80 \\
\hline MnO & 0.02 & 0.02 & 0.04 & 0.05 & 0.03 & 0.06 & 0.03 & 0.07 & 0.03 & 0.04 & 0.05 & 0.05 & 0.08 & 0.06 & 0.02 & 0.00 & 0.06 & 0.06 & 0.02 & 0.03 & 0.03 & 0.00 \\
\hline $\mathrm{FeO}^{\mathrm{a}}$ & 9.75 & 9.36 & 10.25 & 9.73 & 9.95 & 9.56 & 10.36 & 8.75 & 9.25 & 8.69 & 9.20 & 7.67 & 8.87 & 8.58 & 9.15 & 9.59 & 9.20 & 8.51 & 9.59 & 8.96 & 9.01 & 9.31 \\
\hline $\mathrm{CaO}$ & 1.21 & 1.37 & 1.14 & 0.85 & 1.49 & 1.50 & 0.85 & 1.97 & 1.58 & 1.94 & 0.84 & 1.06 & 1.55 & 1.68 & 2.17 & 1.46 & 1.65 & 0.32 & 0.63 & 2.01 & 1.59 & 1.81 \\
\hline $\mathrm{Na}_{2} \mathrm{O}$ & 2.16 & 2.02 & 2.25 & 2.23 & 2.03 & 2.02 & 2.40 & 1.77 & 2.03 & 1.78 & 2.36 & 1.95 & 1.99 & 1.96 & 1.70 & 2.01 & 1.98 & 2.65 & 2.50 & 1.73 & 2.03 & 1.86 \\
\hline $\mathrm{K}_{2} \mathrm{O}$ & 0.03 & 0.03 & 0.03 & 0.03 & 0.03 & 0.02 & 0.02 & 0.02 & 0.04 & 0.00 & 0.02 & 0.01 & 0.03 & 0.02 & 0.01 & 0.02 & 0.04 & 0.02 & 0.02 & 0.02 & 0.01 & 0.02 \\
\hline$F$ & 0.00 & 0.00 & 0.00 & 0.00 & 0.00 & 0.00 & 0.00 & 0.00 & 0.00 & 0.00 & 0.00 & 0.00 & 0.00 & 0.00 & 0.00 & 0.00 & 0.00 & 0.00 & 0.00 & 0.00 & 0.00 & 0.00 \\
\hline $\mathrm{Cl}$ & 0.01 & 0.00 & 0.00 & 0.00 & 0.00 & 0.00 & 0.00 & 0.00 & 0.00 & 0.00 & 0.02 & 0.00 & 0.00 & 0.00 & 0.00 & 0.00 & 0.01 & 0.00 & 0.00 & 0.00 & 0.01 & 0.00 \\
\hline $\mathrm{Cr}_{2} \mathrm{O}_{3}$ & 0.04 & 0.04 & 0.05 & 0.02 & 0.01 & 0.03 & 0.00 & 0.20 & 0.26 & 0.12 & 0.13 & 0.12 & 0.41 & 0.49 & 0.25 & 0.08 & 0.09 & 0.82 & 0.08 & 0.12 & 0.20 & 0.18 \\
\hline Sum & 85.61 & 85.99 & 85.89 & 86.20 & 85.82 & 86.57 & 86.18 & 85.50 & 85.23 & 85.57 & 85.56 & 85.50 & 86.11 & 84.95 & 85.89 & 85.87 & 85.37 & 85.55 & 85.76 & 85.80 & 85.89 & 85.93 \\
\hline$O=F$ & 0.00 & 0.00 & 0.00 & 0.00 & 0.00 & 0.00 & 0.00 & 0.00 & 0.00 & 0.00 & 0.00 & 0.00 & 0.00 & 0.00 & 0.00 & 0.00 & 0.00 & 0.00 & 0.00 & 0.00 & 0.00 & 0.00 \\
\hline Total & 85.61 & 85.99 & 85.89 & 86.20 & 85.82 & 86.57 & 86.18 & 85.50 & 85.23 & 85.57 & 85.56 & 85.50 & 86.11 & 84.95 & 85.89 & 85.87 & 85.37 & 85.55 & 85.76 & 85.80 & 85.89 & 85.93 \\
\hline Si (Atoms p.f.u.) & 6.140 & 6.083 & 6.122 & 6.144 & 6.067 & 6.073 & 6.137 & 6.074 & 6.100 & 6.090 & 6.139 & 6.083 & 6.119 & 6.125 & 6.069 & 6.045 & 6.120 & 6.209 & 6.148 & 6.053 & 6.112 & 6.122 \\
\hline $\operatorname{Al}(T)$ & 0.000 & 0.000 & 0.000 & 0.000 & 0.000 & 0.000 & 0.000 & 0.000 & 0.000 & 0.000 & 0.000 & 0.000 & 0.000 & 0.000 & 0.000 & 0.000 & 0.000 & 0.000 & 0.000 & 0.000 & 0.000 & 0.000 \\
\hline $\mathrm{Al}(\mathrm{Z})$ & 5.562 & 5.622 & 5.533 & 5.680 & 5.557 & 5.632 & 5.685 & 5.672 & 5.514 & 5.616 & 5.580 & 5.948 & 5.591 & 5.572 & 5.526 & 5.537 & 5.553 & 5.770 & 5.520 & 5.662 & 5.543 & 5.465 \\
\hline $\mathrm{Al}(\mathrm{Y})$ & 0.000 & 0.000 & 0.000 & 0.000 & 0.000 & 0.000 & 0.000 & 0.000 & 0.000 & 0.000 & 0.000 & 0.000 & 0.000 & 0.000 & 0.000 & 0.000 & 0.000 & 0.000 & 0.000 & 0.000 & 0.000 & 0.000 \\
\hline $\mathrm{Ti}$ & 0.096 & 0.126 & 0.078 & 0.069 & 0.119 & 0.110 & 0.070 & 0.104 & 0.122 & 0.099 & 0.076 & 0.051 & 0.130 & 0.103 & 0.105 & 0.145 & 0.129 & 0.021 & 0.082 & 0.110 & 0.128 & 0.141 \\
\hline Mg & 1.824 & 1.853 & 1.817 & 1.742 & 1.851 & 1.845 & 1.650 & 1.903 & 1.945 & 1.964 & 1.905 & 1.843 & 1.902 & 1.968 & 2.008 & 1.924 & 1.885 & 1.792 & 1.904 & 1.909 & 1.944 & 1.959 \\
\hline Mn & 0.003 & 0.003 & 0.006 & 0.006 & 0.004 & 0.008 & 0.004 & 0.010 & 0.004 & 0.005 & 0.008 & 0.007 & 0.011 & 0.009 & 0.003 & 0.000 & 0.008 & 0.008 & 0.003 & 0.004 & 0.004 & 0.000 \\
\hline $\mathrm{Fe}$ & 1.375 & 1.312 & 1.443 & 1.358 & 1.402 & 1.332 & 1.453 & 1.237 & 1.315 & 1.225 & 1.292 & 1.068 & 1.247 & 1.223 & 1.290 & 1.349 & 1.304 & 1.200 & 1.344 & 1.261 & 1.268 & 1.313 \\
\hline $\mathrm{Ca}$ & 0.219 & 0.246 & 0.206 & 0.152 & 0.269 & 0.267 & 0.152 & 0.356 & 0.288 & 0.351 & 0.151 & 0.188 & 0.279 & 0.306 & 0.391 & 0.264 & 0.299 & 0.057 & 0.113 & 0.363 & 0.286 & 0.328 \\
\hline $\mathrm{Na}$ & 0.707 & 0.655 & 0.734 & 0.721 & 0.662 & 0.654 & 0.780 & 0.579 & 0.670 & 0.580 & 0.767 & 0.631 & 0.649 & 0.648 & 0.557 & 0.655 & 0.652 & 0.866 & 0.812 & 0.566 & 0.663 & 0.608 \\
\hline K & 0.006 & 0.006 & 0.007 & 0.007 & 0.006 & 0.005 & 0.004 & 0.003 & 0.008 & 0.000 & 0.005 & 0.003 & 0.006 & 0.004 & 0.003 & 0.003 & 0.009 & 0.004 & 0.005 & 0.003 & 0.002 & 0.005 \\
\hline X-site vacancies & 0.067 & 0.093 & 0.053 & 0.119 & 0.063 & 0.074 & 0.063 & 0.062 & 0.034 & 0.069 & 0.077 & 0.178 & 0.066 & 0.041 & 0.049 & 0.078 & 0.040 & 0.072 & 0.070 & 0.069 & 0.049 & 0.060 \\
\hline
\end{tabular}




\begin{tabular}{|c|c|c|c|c|c|c|c|c|c|c|c|c|c|c|c|c|c|c|c|c|c|c|}
\hline Sample & 25962 & & & & & & & & & & & & & 25965 & & & & & & & & \\
\hline $\mathrm{SiO}_{2}$ (wt.\%) & 36.43 & 36.32 & 36.55 & 36.31 & 35.79 & 36.36 & 36.55 & 36.29 & 36.25 & 35.97 & 36.32 & 36.12 & 36.39 & 37.26 & 36.70 & 36.01 & 36.64 & 36.43 & 36.98 & 37.39 & 36.49 & 37.14 \\
\hline $\mathrm{TiO}_{2}$ & 1.16 & 0.49 & 0.57 & 0.69 & 0.64 & 0.58 & 0.53 & 0.53 & 0.46 & 0.68 & 0.79 & 1.15 & 0.80 & 0.06 & 0.30 & 0.08 & 1.22 & 1.20 & 0.03 & 0.13 & 0.15 & 0.11 \\
\hline $\mathrm{Al}_{2} \mathrm{O}_{3}$ & 27.33 & 28.97 & 27.22 & 28.33 & 28.45 & 28.43 & 28.31 & 28.83 & 28.83 & 25.86 & 27.58 & 27.96 & 28.77 & 33.82 & 32.72 & 32.51 & 30.43 & 30.71 & 32.89 & 32.64 & 32.51 & 33.17 \\
\hline MgO & 7.67 & 7.99 & 7.56 & 7.80 & 8.11 & 8.02 & 8.15 & 7.65 & 8.12 & 7.29 & 7.64 & 7.75 & 7.79 & 6.01 & 6.37 & 6.03 & 6.53 & 6.47 & 6.15 & 6.31 & 6.53 & 6.34 \\
\hline MnO & 0.04 & 0.04 & 0.00 & 0.07 & 0.04 & 0.02 & 0.05 & 0.04 & 0.04 & 0.03 & 0.07 & 0.02 & 0.03 & 0.00 & 0.00 & 0.00 & 0.00 & 0.00 & 0.02 & 0.00 & 0.00 & 0.01 \\
\hline $\mathrm{FeO}^{\mathrm{a}}$ & 9.22 & 8.21 & 10.12 & 8.51 & 8.41 & 8.25 & 8.13 & 8.23 & 8.17 & 11.79 & 9.77 & 8.97 & 8.79 & 8.35 & 8.08 & 7.61 & 9.42 & 9.18 & 7.73 & 7.79 & 7.77 & 7.98 \\
\hline $\mathrm{CaO}$ & 1.80 & 1.88 & 0.78 & 1.78 & 2.30 & 1.78 & 2.11 & 1.67 & 1.89 & 0.79 & 1.19 & 1.56 & 1.76 & 0.08 & 0.18 & 0.17 & 0.40 & 0.38 & 0.12 & 0.11 & 0.11 & 0.13 \\
\hline $\mathrm{Na}_{2} \mathrm{O}$ & 1.87 & 1.81 & 2.49 & 1.95 & 1.60 & 1.88 & 1.73 & 1.97 & 1.90 & 2.41 & 2.22 & 1.93 & 1.79 & 2.32 & 2.43 & 2.28 & 2.71 & 2.63 & 2.34 & 2.25 & 2.30 & 2.31 \\
\hline $\mathrm{K}_{2} \mathrm{O}$ & 0.00 & 0.02 & 0.03 & 0.01 & 0.02 & 0.03 & 0.01 & 0.00 & 0.01 & 0.04 & 0.03 & 0.04 & 0.02 & 0.01 & 0.02 & 0.03 & 0.01 & 0.02 & 0.01 & 0.01 & 0.02 & 0.01 \\
\hline$F$ & 0.00 & 0.00 & 0.00 & 0.00 & 0.00 & 0.00 & 0.00 & 0.00 & 0.00 & 0.00 & 0.00 & 0.00 & 0.00 & 0.00 & 0.07 & 0.22 & 0.11 & 0.31 & 0.00 & 0.07 & 0.02 & 0.00 \\
\hline $\mathrm{Cl}$ & 0.00 & 0.00 & 0.01 & 0.01 & 0.00 & 0.00 & 0.00 & 0.01 & 0.00 & 0.01 & 0.01 & 0.01 & 0.01 & 0.00 & 0.00 & 0.01 & 0.01 & 0.00 & 0.01 & 0.00 & 0.00 & 0.00 \\
\hline $\mathrm{Cr}_{2} \mathrm{O}_{3}$ & 0.14 & 0.03 & 0.07 & 0.04 & 0.03 & 0.07 & 0.07 & 0.08 & 0.07 & 0.23 & 0.27 & 0.19 & 0.24 & 0.02 & 0.02 & 0.03 & 0.03 & 0.02 & 0.01 & 0.02 & 0.01 & 0.00 \\
\hline Sum & 85.66 & 85.76 & 85.40 & 85.49 & 85.39 & 85.41 & 85.64 & 85.30 & 85.74 & 85.09 & 85.89 & 85.70 & 86.38 & 87.93 & 86.88 & 84.96 & 87.52 & 87.35 & 86.29 & 86.71 & 85.92 & 87.21 \\
\hline$O=F$ & 0.00 & 0.00 & 0.00 & 0.00 & 0.00 & 0.00 & 0.00 & 0.00 & 0.00 & 0.00 & 0.00 & 0.00 & 0.00 & 0.00 & -0.03 & -0.09 & -0.05 & -0.13 & 0.00 & -0.03 & -0.01 & 0.00 \\
\hline Total & 85.66 & 85.76 & 85.40 & 85.49 & 85.39 & 85.41 & 85.64 & 85.30 & 85.74 & 85.08 & 85.89 & 85.70 & 86.38 & 87.93 & 86.86 & 84.86 & 87.47 & 87.22 & 86.28 & 86.68 & 85.91 & 87.21 \\
\hline Si (Atoms p.f.u.) ${ }^{b}$ & 6.160 & 6.077 & 6.174 & 6.118 & 6.034 & 6.116 & 6.138 & 6.116 & 6.071 & 6.151 & 6.117 & 6.087 & 6.072 & 6.002 & 6.000 & 6.019 & 6.037 & 6.015 & 6.068 & 6.104 & 6.003 & 6.025 \\
\hline $\operatorname{Al}(T)$ & 0.000 & 0.000 & 0.000 & 0.000 & 0.000 & 0.000 & 0.000 & 0.000 & 0.000 & 0.000 & 0.000 & 0.000 & 0.000 & 0.000 & 0.000 & 0.000 & 0.000 & 0.000 & 0.000 & 0.000 & 0.000 & 0.000 \\
\hline $\mathrm{Al}(\mathrm{Z})$ & 5.449 & 5.714 & 5.421 & 5.628 & 5.655 & 5.638 & 5.606 & 5.729 & 5.694 & 5.214 & 5.477 & 5.555 & 5.658 & 6.000 & 6.000 & 6.000 & 5.910 & 5.976 & 6.000 & 6.000 & 6.000 & 6.000 \\
\hline $\mathrm{Al}(\mathrm{Y})$ & 0.000 & 0.000 & 0.000 & 0.000 & 0.000 & 0.000 & 0.000 & 0.000 & 0.000 & 0.000 & 0.000 & 0.000 & 0.000 & 0.423 & 0.306 & 0.406 & 0.000 & 0.000 & 0.361 & 0.282 & 0.307 & 0.344 \\
\hline $\mathrm{Ti}$ & 0.148 & 0.062 & 0.073 & 0.088 & 0.081 & 0.074 & 0.067 & 0.068 & 0.058 & 0.087 & 0.100 & 0.146 & 0.100 & 0.008 & 0.037 & 0.009 & 0.151 & 0.149 & 0.004 & 0.015 & 0.018 & 0.013 \\
\hline Mg & 1.933 & 1.992 & 1.903 & 1.958 & 2.038 & 2.009 & 2.040 & 1.921 & 2.026 & 1.857 & 1.918 & 1.946 & 1.938 & 1.442 & 1.552 & 1.502 & 1.603 & 1.593 & 1.504 & 1.536 & 1.602 & 1.533 \\
\hline Mn & 0.006 & 0.006 & 0.000 & 0.009 & 0.006 & 0.003 & 0.008 & 0.005 & 0.006 & 0.005 & 0.010 & 0.002 & 0.005 & 0.000 & 0.000 & 0.000 & 0.000 & 0.000 & 0.003 & 0.000 & 0.000 & 0.002 \\
\hline $\mathrm{Fe}$ & 1.304 & 1.149 & 1.430 & 1.199 & 1.186 & 1.160 & 1.141 & 1.160 & 1.145 & 1.686 & 1.377 & 1.264 & 1.226 & 1.125 & 1.105 & 1.064 & 1.298 & 1.267 & 1.060 & 1.063 & 1.070 & 1.083 \\
\hline $\mathrm{Ca}$ & 0.326 & 0.336 & 0.140 & 0.322 & 0.416 & 0.320 & 0.379 & 0.302 & 0.339 & 0.144 & 0.214 & 0.282 & 0.314 & 0.014 & 0.032 & 0.030 & 0.070 & 0.067 & 0.021 & 0.018 & 0.019 & 0.022 \\
\hline $\mathrm{Na}$ & 0.613 & 0.588 & 0.815 & 0.638 & 0.522 & 0.612 & 0.565 & 0.644 & 0.618 & 0.800 & 0.725 & 0.632 & 0.579 & 0.725 & 0.770 & 0.737 & 0.867 & 0.841 & 0.746 & 0.712 & 0.734 & 0.727 \\
\hline K & 0.000 & 0.005 & 0.007 & 0.003 & 0.005 & 0.006 & 0.002 & 0.001 & 0.002 & 0.009 & 0.007 & 0.008 & 0.004 & 0.001 & 0.004 & 0.006 & 0.003 & 0.004 & 0.002 & 0.001 & 0.004 & 0.001 \\
\hline X-site vacancies & 0.061 & 0.071 & 0.038 & 0.037 & 0.057 & 0.062 & 0.054 & 0.053 & 0.041 & 0.048 & 0.053 & 0.078 & 0.104 & 0.260 & 0.194 & 0.228 & 0.060 & 0.088 & 0.232 & 0.269 & 0.244 & 0.249 \\
\hline
\end{tabular}




\begin{tabular}{|c|c|c|c|c|c|c|c|c|c|c|c|c|c|c|c|c|c|c|c|c|c|c|}
\hline Sample & 25965 & & & & & & & & & & & & 25966 & & & & & & & & & \\
\hline $\mathrm{SiO}_{2}$ (wt.\%) & 37.43 & 35.86 & 37.46 & 36.73 & 37.63 & 37.76 & 37.12 & 36.73 & 36.48 & 37.76 & 36.31 & 36.85 & 36.41 & 37.48 & 37.30 & 36.70 & 36.87 & 37.05 & 37.00 & 36.67 & 37.36 & 36.58 \\
\hline $\mathrm{TiO}_{2}$ & 0.52 & 0.45 & 1.00 & 1.62 & 0.25 & 0.32 & 1.00 & 1.05 & 1.05 & 0.17 & 1.05 & 0.80 & 0.50 & 0.21 & 0.10 & 0.59 & 0.43 & 0.24 & 0.39 & 0.64 & 0.28 & 0.98 \\
\hline $\mathrm{Al}_{2} \mathrm{O}_{3}$ & 32.90 & 31.55 & 31.49 & 30.92 & 33.57 & 32.93 & 31.69 & 31.23 & 31.13 & 33.83 & 30.44 & 30.84 & 32.02 & 33.12 & 33.55 & 32.44 & 32.62 & 33.07 & 32.63 & 31.97 & 33.37 & 31.72 \\
\hline MgO & 6.17 & 5.50 & 7.01 & 6.39 & 6.14 & 5.97 & 6.78 & 6.39 & 6.59 & 6.45 & 6.74 & 6.60 & 6.22 & 5.94 & 5.73 & 6.28 & 6.02 & 5.69 & 6.12 & 5.99 & 5.46 & 6.86 \\
\hline MnO & 0.04 & 0.05 & 0.02 & 0.02 & 0.02 & 0.03 & 0.01 & 0.00 & 0.00 & 0.01 & 0.01 & 0.00 & 0.01 & 0.03 & 0.02 & 0.00 & 0.03 & 0.00 & 0.02 & 0.04 & 0.03 & 0.00 \\
\hline $\mathrm{FeO}^{\mathrm{a}}$ & 8.43 & 7.25 & 8.12 & 9.07 & 7.83 & 8.44 & 8.40 & 9.29 & 8.72 & 7.87 & 8.68 & 8.60 & 8.89 & 8.95 & 8.66 & 9.04 & 9.69 & 9.40 & 9.94 & 10.19 & 9.05 & 9.19 \\
\hline $\mathrm{CaO}$ & 0.18 & 0.17 & 0.59 & 0.43 & 0.20 & 0.19 & 0.57 & 0.33 & 0.34 & 0.15 & 0.49 & 0.36 & 0.40 & 0.23 & 0.15 & 0.33 & 0.22 & 0.14 & 0.23 & 0.36 & 0.20 & 0.93 \\
\hline $\mathrm{Na}_{2} \mathrm{O}$ & 2.53 & 2.22 & 2.73 & 2.54 & 2.27 & 2.22 & 2.47 & 2.62 & 2.58 & 2.43 & 2.54 & 2.67 & 2.30 & 2.18 & 2.12 & 2.60 & 2.37 & 2.27 & 2.35 & 2.49 & 2.26 & 2.32 \\
\hline $\mathrm{K}_{2} \mathrm{O}$ & 0.01 & 0.02 & 0.02 & 0.01 & 0.02 & 0.02 & 0.02 & 0.02 & 0.02 & 0.01 & 0.04 & 0.02 & 0.00 & 0.00 & 0.01 & 0.00 & 0.01 & 0.02 & 0.01 & 0.01 & 0.00 & 0.01 \\
\hline$F$ & 0.00 & 0.36 & 0.29 & 0.22 & 0.00 & 0.29 & 0.40 & 0.24 & 0.07 & 0.00 & 0.33 & 0.47 & 0.42 & 0.00 & 0.00 & 0.25 & 0.42 & 0.13 & 0.07 & 0.29 & 0.18 & 0.47 \\
\hline $\mathrm{Cl}$ & 0.00 & 0.00 & 0.00 & 0.01 & 0.00 & 0.00 & 0.02 & 0.01 & 0.01 & 0.00 & 0.00 & 0.00 & 0.01 & 0.01 & 0.01 & 0.01 & 0.00 & 0.00 & 0.00 & 0.00 & 0.01 & 0.00 \\
\hline $\mathrm{Cr}_{2} \mathrm{O}_{3}$ & 0.00 & 0.04 & 0.04 & 0.02 & 0.05 & 0.10 & 0.01 & 0.01 & 0.03 & 0.00 & 0.01 & 0.04 & 0.01 & 0.00 & 0.00 & 0.00 & 0.00 & 0.00 & 0.00 & 0.00 & 0.02 & 0.02 \\
\hline Sum & 88.20 & 83.47 & 88.77 & 88.00 & 87.98 & 88.27 & 88.48 & 87.92 & 87.01 & 88.68 & 86.66 & 87.25 & 87.19 & 88.14 & 87.64 & 88.24 & 88.68 & 88.02 & 88.74 & 88.65 & 88.20 & 89.08 \\
\hline$O=F$ & 0.00 & -0.15 & -0.12 & -0.09 & 0.00 & -0.12 & -0.17 & -0.10 & -0.03 & 0.00 & -0.14 & -0.20 & -0.18 & 0.00 & 0.00 & -0.10 & -0.18 & -0.06 & -0.03 & -0.12 & -0.08 & -0.20 \\
\hline Total & 88.20 & 83.32 & 88.64 & 87.90 & 87.98 & 88.15 & 88.31 & 87.81 & 86.98 & 88.68 & 86.52 & 87.05 & 87.01 & 88.14 & 87.64 & 88.14 & 88.50 & 87.96 & 88.71 & 88.53 & 88.13 & 88.88 \\
\hline Si (Atoms p.f.u.) ${ }^{b}$ & 6.045 & 6.133 & 6.068 & 6.020 & 6.061 & 6.103 & 6.028 & 6.013 & 6.008 & 6.026 & 6.031 & 6.085 & 5.985 & 6.042 & 6.034 & 5.964 & 5.963 & 6.004 & 5.955 & 5.958 & 6.050 & 5.923 \\
\hline $\operatorname{Al}(\mathrm{T})$ & 0.000 & 0.000 & 0.000 & 0.000 & 0.000 & 0.000 & 0.000 & 0.000 & 0.000 & 0.000 & 0.000 & 0.000 & 0.015 & 0.000 & 0.000 & 0.036 & 0.037 & 0.000 & 0.045 & 0.042 & 0.000 & 0.077 \\
\hline $\mathrm{Al}(\mathrm{Z})$ & 6.000 & 6.000 & 6.000 & 5.974 & 6.000 & 6.000 & 6.000 & 6.000 & 6.000 & 6.000 & 5.961 & 6.000 & 6.000 & 6.000 & 6.000 & 6.000 & 6.000 & 6.000 & 6.000 & 6.000 & 6.000 & 5.980 \\
\hline $\operatorname{Al}(Y)$ & 0.263 & 0.362 & 0.015 & 0.000 & 0.375 & 0.274 & 0.068 & 0.027 & 0.045 & 0.366 & 0.000 & 0.005 & 0.190 & 0.295 & 0.399 & 0.178 & 0.183 & 0.319 & 0.146 & 0.081 & 0.370 & 0.000 \\
\hline $\mathrm{Ti}$ & 0.063 & 0.057 & 0.122 & 0.200 & 0.031 & 0.039 & 0.122 & 0.129 & 0.130 & 0.020 & 0.131 & 0.099 & 0.061 & 0.025 & 0.012 & 0.072 & 0.052 & 0.029 & 0.048 & 0.078 & 0.034 & 0.119 \\
\hline $\mathbf{M g}$ & 1.485 & 1.403 & 1.692 & 1.560 & 1.475 & 1.438 & 1.641 & 1.559 & 1.617 & 1.535 & 1.669 & 1.624 & 1.524 & 1.427 & 1.381 & 1.522 & 1.451 & 1.375 & 1.467 & 1.451 & 1.317 & 1.657 \\
\hline $\mathrm{Mn}$ & 0.005 & 0.007 & 0.003 & 0.003 & 0.003 & 0.004 & 0.001 & 0.000 & 0.000 & 0.002 & 0.002 & 0.000 & 0.002 & 0.004 & 0.002 & 0.000 & 0.004 & 0.000 & 0.002 & 0.006 & 0.003 & 0.000 \\
\hline $\mathrm{Fe}$ & 1.139 & 1.037 & 1.100 & 1.244 & 1.055 & 1.141 & 1.141 & 1.272 & 1.200 & 1.051 & 1.206 & 1.187 & 1.223 & 1.207 & 1.171 & 1.229 & 1.310 & 1.274 & 1.337 & 1.384 & 1.226 & 1.244 \\
\hline $\mathrm{Ca}$ & 0.031 & 0.031 & 0.102 & 0.076 & 0.035 & 0.032 & 0.099 & 0.058 & 0.060 & 0.026 & 0.088 & 0.064 & 0.070 & 0.040 & 0.026 & 0.058 & 0.038 & 0.025 & 0.039 & 0.063 & 0.034 & 0.161 \\
\hline $\mathrm{Na}$ & 0.793 & 0.737 & 0.858 & 0.807 & 0.708 & 0.695 & 0.777 & 0.833 & 0.825 & 0.751 & 0.819 & 0.856 & 0.733 & 0.682 & 0.664 & 0.819 & 0.744 & 0.714 & 0.732 & 0.785 & 0.709 & 0.730 \\
\hline K & 0.001 & 0.004 & 0.004 & 0.003 & 0.004 & 0.004 & 0.005 & 0.004 & 0.003 & 0.001 & 0.008 & 0.004 & 0.000 & 0.001 & 0.003 & 0.001 & 0.002 & 0.003 & 0.001 & 0.002 & 0.000 & 0.003 \\
\hline X-site vacancies & 0.175 & 0.229 & 0.037 & 0.114 & 0.254 & 0.268 & 0.119 & 0.105 & 0.112 & 0.222 & 0.086 & 0.076 & 0.197 & 0.277 & 0.307 & 0.122 & 0.216 & 0.258 & 0.227 & 0.150 & 0.257 & 0.106 \\
\hline
\end{tabular}




\begin{tabular}{|c|c|c|c|c|c|c|c|c|c|c|c|c|c|c|c|c|c|c|c|c|c|c|}
\hline \multirow{2}{*}{$\begin{array}{l}\text { Sample } \\
\mathrm{SiO}_{2} \text { (wt.\%) }\end{array}$} & \multicolumn{15}{|l|}{25966} & \multicolumn{7}{|l|}{25970} \\
\hline & 36.68 & 37.29 & 36.52 & 37.28 & 36.68 & 35.81 & 37.34 & 37.17 & 36.87 & 37.01 & 36.42 & 36.13 & 36.43 & 37.01 & 36.85 & 36.44 & 35.80 & 36.67 & 35.51 & 36.13 & 36.73 & 36.77 \\
\hline $\mathrm{TiO}_{2}$ & 0.87 & 0.26 & 0.72 & 0.22 & 0.79 & 0.81 & 0.20 & 0.27 & 0.81 & 0.88 & 1.80 & 2.20 & 0.75 & 0.40 & 0.51 & 0.96 & 0.67 & 0.33 & 0.33 & 0.22 & 0.49 & 0.41 \\
\hline $\mathrm{Al}_{2} \mathrm{O}_{3}$ & 31.82 & 33.20 & 32.10 & 33.29 & 31.94 & 30.11 & 34.00 & 33.34 & 32.82 & 32.68 & 30.80 & 30.22 & 31.99 & 33.25 & 32.94 & 26.63 & 26.28 & 29.10 & 25.93 & 26.54 & 29.21 & 29.27 \\
\hline MgO & 6.38 & 5.90 & 6.14 & 5.80 & 5.89 & 6.66 & 5.14 & 5.38 & 5.34 & 5.71 & 5.56 & 5.01 & 5.50 & 5.66 & 5.55 & 6.65 & 6.99 & 7.72 & 6.49 & 6.15 & 8.15 & 7.68 \\
\hline MnO & 0.05 & 0.00 & 0.03 & 0.04 & 0.04 & 0.00 & 0.03 & 0.02 & 0.00 & 0.00 & 0.00 & 0.03 & 0.00 & 0.01 & 0.00 & 0.00 & 0.01 & 0.00 & 0.04 & 0.05 & 0.00 & 0.00 \\
\hline $\mathrm{FeO}^{\mathrm{a}}$ & 9.07 & 9.10 & 9.21 & 9.12 & 9.33 & 9.98 & 8.89 & 9.09 & 9.33 & 9.03 & 10.32 & 10.98 & 9.63 & 8.60 & 8.75 & 11.57 & 13.07 & 8.76 & 14.36 & 13.90 & 7.81 & 8.14 \\
\hline $\mathrm{CaO}$ & 0.56 & 0.26 & 0.59 & 0.29 & 0.53 & 1.09 & 0.10 & 0.13 & 0.23 & 0.25 & 0.33 & 0.28 & 0.28 & 0.13 & 0.19 & 0.90 & 0.79 & 1.26 & 0.98 & 0.72 & 1.16 & 1.12 \\
\hline $\mathrm{Na}_{2} \mathrm{O}$ & 2.46 & 2.27 & 2.34 & 2.35 & 2.46 & 2.42 & 2.02 & 2.06 & 2.51 & 2.55 & 2.53 & 2.43 & 2.48 & 2.36 & 2.32 & 2.52 & 2.29 & 2.19 & 2.29 & 2.43 & 2.28 & 2.18 \\
\hline $\mathrm{K}_{2} \mathrm{O}$ & 0.02 & 0.00 & 0.02 & 0.00 & 0.00 & 0.01 & 0.01 & 0.00 & 0.00 & 0.01 & 0.02 & 0.02 & 0.01 & 0.02 & 0.01 & 0.01 & 0.02 & 0.01 & 0.04 & 0.03 & 0.01 & 0.00 \\
\hline$F$ & 0.27 & 0.00 & 0.00 & 0.40 & 0.27 & 0.00 & 0.20 & 0.36 & 0.60 & 0.65 & 0.36 & 0.53 & 0.13 & 0.25 & 0.05 & 0.00 & 0.00 & 0.00 & 0.00 & 0.00 & 0.00 & 0.00 \\
\hline $\mathrm{Cl}$ & 0.00 & 0.00 & 0.01 & 0.01 & 0.00 & 0.01 & 0.00 & 0.00 & 0.00 & 0.01 & 0.01 & 0.00 & 0.00 & 0.00 & 0.01 & 0.01 & 0.00 & 0.00 & 0.00 & 0.00 & 0.00 & 0.01 \\
\hline $\mathrm{Cr}_{2} \mathrm{O}_{3}$ & 0.01 & 0.00 & 0.01 & 0.00 & 0.00 & 0.04 & 0.01 & 0.01 & 0.03 & 0.01 & 0.01 & 0.03 & 0.02 & 0.01 & 0.03 & 0.00 & 0.02 & 0.01 & 0.00 & 0.02 & 0.00 & 0.00 \\
\hline Sum & 88.19 & 88.28 & 87.68 & 88.81 & 87.92 & 86.94 & 87.94 & 87.84 & 88.53 & 88.78 & 88.15 & 87.84 & 87.22 & 87.69 & 87.19 & 85.70 & 85.93 & 86.05 & 85.96 & 86.19 & 85.83 & 85.56 \\
\hline$O=F$ & -0.11 & 0.00 & 0.00 & -0.17 & -0.11 & 0.00 & -0.09 & -0.15 & -0.25 & -0.27 & -0.15 & -0.23 & -0.06 & -0.10 & -0.02 & 0.00 & 0.00 & 0.00 & 0.00 & 0.00 & 0.00 & 0.00 \\
\hline Total & 88.07 & 88.28 & 87.67 & 88.64 & 87.80 & 86.94 & 87.85 & 87.69 & 88.28 & 88.51 & 87.99 & 87.62 & 87.16 & 87.59 & 87.17 & 85.70 & 85.93 & 86.05 & 85.96 & 86.19 & 85.83 & 85.56 \\
\hline Si (Atoms p.f.u.) ${ }^{b}$ & 5.982 & 6.013 & 5.969 & 6.012 & 6.010 & 5.956 & 6.042 & 6.039 & 6.017 & 6.017 & 6.003 & 6.017 & 6.008 & 6.025 & 6.031 & 6.202 & 6.058 & 6.107 & 6.049 & 6.130 & 6.107 & 6.140 \\
\hline $\operatorname{Al}(T)$ & 0.018 & 0.000 & 0.031 & 0.000 & 0.000 & 0.044 & 0.000 & 0.000 & 0.000 & 0.000 & 0.000 & 0.000 & 0.000 & 0.000 & 0.000 & 0.000 & 0.000 & 0.000 & 0.000 & 0.000 & 0.000 & 0.000 \\
\hline $\mathrm{Al}(\mathrm{Z})$ & 6.000 & 6.000 & 6.000 & 6.000 & 6.000 & 5.859 & 6.000 & 6.000 & 6.000 & 6.000 & 5.986 & 5.934 & 6.000 & 6.000 & 6.000 & 5.343 & 5.242 & 5.715 & 5.209 & 5.307 & 5.726 & 5.762 \\
\hline $\mathrm{Al}(\mathrm{Y})$ & 0.100 & 0.312 & 0.153 & 0.330 & 0.171 & 0.000 & 0.486 & 0.386 & 0.313 & 0.265 & 0.000 & 0.000 & 0.220 & 0.381 & 0.356 & 0.000 & 0.000 & 0.000 & 0.000 & 0.000 & 0.000 & 0.000 \\
\hline $\mathrm{Ti}$ & 0.106 & 0.031 & 0.088 & 0.027 & 0.097 & 0.101 & 0.025 & 0.033 & 0.100 & 0.108 & 0.223 & 0.275 & 0.093 & 0.049 & 0.063 & 0.123 & 0.086 & 0.041 & 0.042 & 0.028 & 0.061 & 0.052 \\
\hline Mg & 1.550 & 1.417 & 1.496 & 1.395 & 1.438 & 1.651 & 1.241 & 1.303 & 1.297 & 1.383 & 1.365 & 1.242 & 1.351 & 1.373 & 1.353 & 1.686 & 1.763 & 1.917 & 1.648 & 1.556 & 2.020 & 1.910 \\
\hline Mn & 0.007 & 0.000 & 0.005 & 0.005 & 0.006 & 0.000 & 0.003 & 0.003 & 0.000 & 0.000 & 0.000 & 0.004 & 0.000 & 0.002 & 0.000 & 0.000 & 0.001 & 0.000 & 0.006 & 0.007 & 0.000 & 0.000 \\
\hline $\mathrm{Fe}$ & 1.238 & 1.227 & 1.258 & 1.230 & 1.278 & 1.388 & 1.204 & 1.235 & 1.273 & 1.228 & 1.422 & 1.529 & 1.328 & 1.170 & 1.197 & 1.646 & 1.849 & 1.220 & 2.046 & 1.972 & 1.086 & 1.136 \\
\hline $\mathrm{Ca}$ & 0.099 & 0.046 & 0.104 & 0.051 & 0.093 & 0.194 & 0.017 & 0.023 & 0.040 & 0.043 & 0.058 & 0.051 & 0.049 & 0.022 & 0.033 & 0.164 & 0.142 & 0.225 & 0.178 & 0.131 & 0.207 & 0.200 \\
\hline $\mathrm{Na}$ & 0.779 & 0.709 & 0.741 & 0.736 & 0.782 & 0.782 & 0.633 & 0.650 & 0.794 & 0.805 & 0.808 & 0.784 & 0.792 & 0.745 & 0.737 & 0.832 & 0.750 & 0.708 & 0.756 & 0.800 & 0.736 & 0.707 \\
\hline K & 0.004 & 0.000 & 0.003 & 0.000 & 0.000 & 0.003 & 0.003 & 0.001 & 0.001 & 0.001 & 0.005 & 0.004 & 0.003 & 0.004 & 0.002 & 0.003 & 0.005 & 0.001 & 0.008 & 0.007 & 0.002 & 0.000 \\
\hline X-site vacancies & 0.119 & 0.245 & 0.152 & 0.213 & 0.125 & 0.022 & 0.348 & 0.326 & 0.166 & 0.151 & 0.129 & 0.161 & 0.156 & 0.229 & 0.228 & 0.001 & 0.102 & 0.065 & 0.058 & 0.062 & 0.055 & 0.094 \\
\hline
\end{tabular}




\begin{tabular}{|c|c|c|c|c|c|c|c|c|c|c|c|c|c|c|c|c|c|c|c|c|c|c|}
\hline Sample & 25970 & & & & & & & & 26577 & & & & & & & & & & & & & \\
\hline $\mathrm{SiO}_{2}$ (wt.\%) & 37.19 & 37.24 & 36.79 & 36.30 & 36.06 & 36.19 & 35.71 & 36.18 & 36.39 & 36.70 & 34.97 & 36.69 & 36.84 & 38.12 & 36.62 & 36.42 & 36.99 & 36.38 & 36.85 & 38.73 & 36.98 & 36.48 \\
\hline $\mathrm{TiO}_{2}$ & 0.31 & 0.54 & 0.64 & 0.65 & 0.27 & 0.22 & 0.33 & 0.43 & 0.11 & 0.20 & 0.15 & 0.26 & 0.11 & 0.17 & 0.36 & 0.21 & 0.06 & 0.22 & 0.25 & 0.82 & 0.20 & 0.29 \\
\hline $\mathrm{Al}_{2} \mathrm{O}_{3}$ & 30.84 & 29.17 & 29.35 & 27.34 & 27.12 & 27.61 & 26.40 & 27.57 & 30.94 & 32.17 & 30.03 & 32.18 & 32.11 & 31.22 & 31.65 & 31.88 & 33.96 & 32.92 & 31.74 & 29.63 & 30.63 & 30.78 \\
\hline MgO & 7.70 & 7.82 & 7.72 & 7.12 & 6.13 & 6.22 & 6.11 & 6.16 & 5.63 & 5.95 & 5.61 & 5.99 & 6.13 & 5.25 & 5.65 & 5.18 & 3.64 & 4.35 & 4.16 & 5.74 & 5.52 & 4.96 \\
\hline MnO & 0.00 & 0.00 & 0.00 & 0.00 & 0.01 & 0.03 & 0.07 & 0.07 & 0.01 & 0.01 & 0.00 & 0.01 & 0.03 & 0.04 & 0.00 & 0.04 & 0.01 & 0.01 & 0.00 & 0.00 & 0.04 & 0.00 \\
\hline $\mathrm{FeO}^{\mathrm{a}}$ & 6.99 & 7.80 & 8.16 & 11.13 & 12.87 & 12.54 & 14.01 & 12.81 & 10.01 & 9.68 & 8.69 & 9.30 & 9.43 & 10.56 & 10.03 & 10.79 & 11.31 & 11.27 & 10.67 & 8.90 & 9.85 & 10.18 \\
\hline $\mathrm{CaO}$ & 0.64 & 1.31 & 1.15 & 0.98 & 0.86 & 0.71 & 0.92 & 0.87 & 0.07 & 0.14 & 0.10 & 0.10 & 0.14 & 0.08 & 0.18 & 0.10 & 0.03 & 0.16 & 0.05 & 0.40 & 0.15 & 0.12 \\
\hline $\mathrm{Na}_{2} \mathrm{O}$ & 2.28 & 2.26 & 2.30 & 2.33 & 2.45 & 2.45 & 2.39 & 2.47 & 2.84 & 3.03 & 2.71 & 2.87 & 3.02 & 2.54 & 2.89 & 2.74 & 1.78 & 1.95 & 1.85 & 2.01 & 2.43 & 2.54 \\
\hline $\mathrm{K}_{2} \mathrm{O}$ & 0.00 & 0.00 & 0.01 & 0.02 & 0.04 & 0.04 & 0.03 & 0.04 & 0.00 & 0.01 & 0.02 & 0.02 & 0.00 & 0.00 & 0.05 & 0.01 & 0.02 & 0.02 & 0.01 & 0.01 & 0.01 & 0.01 \\
\hline$F$ & 0.00 & 0.00 & 0.00 & 0.00 & 0.00 & 0.00 & 0.00 & 0.00 & 0.28 & 0.00 & 0.16 & 0.23 & 0.42 & 0.00 & 0.11 & 0.02 & 0.25 & 0.07 & 0.00 & 0.00 & 0.00 & 0.00 \\
\hline $\mathrm{Cl}$ & 0.00 & 0.02 & 0.00 & 0.00 & 0.00 & 0.01 & 0.01 & 0.00 & 0.01 & 0.00 & 0.01 & 0.00 & 0.00 & 0.00 & 0.01 & 0.00 & 0.01 & 0.00 & 0.00 & 0.00 & 0.01 & 0.00 \\
\hline $\mathrm{Cr}_{2} \mathrm{O}_{3}$ & 0.02 & 0.03 & 0.04 & 0.01 & 0.02 & 0.04 & 0.03 & 0.01 & 0.00 & 0.03 & 0.02 & 0.00 & 0.01 & 0.00 & 0.00 & 0.00 & 0.00 & 0.01 & 0.02 & 0.00 & 0.02 & 0.01 \\
\hline Sum & 85.98 & 86.19 & 86.15 & 85.89 & 85.83 & 86.06 & 86.00 & 86.60 & 86.30 & 87.90 & 82.45 & 87.64 & 88.23 & 87.98 & 87.56 & 87.39 & 88.05 & 87.36 & 85.61 & 86.24 & 85.84 & 85.37 \\
\hline $\mathrm{O}=\mathrm{F}$ & 0.00 & 0.00 & 0.00 & 0.00 & 0.00 & 0.00 & 0.00 & 0.00 & -0.12 & 0.00 & -0.07 & -0.10 & -0.18 & 0.00 & -0.05 & -0.01 & -0.11 & -0.03 & 0.00 & 0.00 & 0.00 & 0.00 \\
\hline Total & 85.98 & 86.18 & 86.15 & 85.89 & 85.83 & 86.06 & 86.00 & 86.60 & 86.18 & 87.90 & 82.38 & 87.55 & 88.05 & 87.98 & 87.51 & 87.38 & 87.94 & 87.33 & & & & \\
\hline Si (Atoms p.f.u.) & 6.122 & 6.193 & 6.118 & 6.122 & 6.136 & 6.121 & 6.089 & 6.101 & 6.084 & 6.001 & 6.092 & 6.012 & 6.018 & 6.233 & 6.036 & 6.008 & 6.034 & 5.980 & 6.170 & 6.436 & 6.181 & 6.156 \\
\hline $\mathrm{Al}(\mathrm{T})$ & 0.000 & 0.000 & 0.000 & 0.000 & 0.000 & 0.000 & 0.000 & 0.000 & 0.000 & 0.000 & 0.000 & 0.000 & 0.000 & 0.000 & 0.000 & 0.000 & 0.000 & 0.020 & 0.000 & 0.000 & 0.000 & 0.000 \\
\hline $\mathrm{Al}(\mathrm{Z})$ & 5.987 & 5.718 & 5.755 & 5.435 & 5.440 & 5.506 & 5.307 & 5.481 & 6.000 & 6.000 & 6.000 & 6.000 & 6.000 & 6.000 & 6.000 & 6.000 & 6.000 & 6.000 & 6.000 & 5.805 & 6.000 & 6.000 \\
\hline $\mathrm{Al}(\mathrm{Y})$ & 0.000 & 0.000 & 0.000 & 0.000 & 0.000 & 0.000 & 0.000 & 0.000 & 0.098 & 0.201 & 0.168 & 0.217 & 0.184 & 0.017 & 0.150 & 0.199 & 0.530 & 0.357 & 0.265 & 0.000 & 0.036 & 0.124 \\
\hline $\mathrm{Ti}$ & 0.038 & 0.068 & 0.081 & 0.083 & 0.035 & 0.028 & 0.043 & 0.055 & 0.013 & 0.025 & 0.019 & 0.032 & 0.014 & 0.021 & 0.045 & 0.026 & 0.007 & 0.028 & 0.031 & 0.102 & 0.025 & 0.037 \\
\hline Mg & 1.890 & 1.937 & 1.912 & 1.790 & 1.556 & 1.567 & 1.553 & 1.547 & 1.403 & 1.449 & 1.455 & 1.464 & 1.492 & 1.279 & 1.387 & 1.274 & 0.884 & 1.065 & 1.039 & 1.420 & 1.375 & 1.246 \\
\hline Mn & 0.000 & 0.000 & 0.000 & 0.001 & 0.001 & 0.005 & 0.010 & 0.009 & 0.002 & 0.001 & 0.000 & 0.001 & 0.004 & 0.005 & 0.000 & 0.005 & 0.001 & 0.001 & 0.000 & 0.000 & 0.005 & 0.000 \\
\hline $\mathrm{Fe}$ & 0.963 & 1.085 & 1.134 & 1.570 & 1.832 & 1.774 & 1.998 & 1.807 & 1.399 & 1.323 & 1.266 & 1.275 & 1.288 & 1.444 & 1.382 & 1.488 & 1.543 & 1.549 & 1.495 & 1.236 & 1.377 & 1.437 \\
\hline $\mathrm{Ca}$ & 0.113 & 0.233 & 0.205 & 0.178 & 0.156 & 0.129 & 0.169 & 0.157 & 0.013 & 0.024 & 0.019 & 0.017 & 0.025 & 0.014 & 0.032 & 0.018 & 0.005 & 0.029 & 0.009 & 0.072 & 0.027 & 0.021 \\
\hline $\mathrm{Na}$ & 0.729 & 0.730 & 0.740 & 0.763 & 0.808 & 0.803 & 0.792 & 0.806 & 0.921 & 0.960 & 0.914 & 0.911 & 0.955 & 0.804 & 0.925 & 0.876 & 0.563 & 0.620 & 0.601 & 0.648 & 0.789 & 0.831 \\
\hline $\mathrm{K}$ & 0.000 & 0.000 & 0.002 & 0.003 & 0.009 & 0.008 & 0.005 & 0.009 & 0.000 & 0.002 & 0.003 & 0.005 & 0.000 & 0.000 & 0.009 & 0.002 & 0.004 & 0.004 & 0.002 & 0.002 & 0.003 & 0.002 \\
\hline X-site vacancies & 0.158 & 0.037 & 0.053 & 0.056 & 0.027 & 0.060 & 0.034 & 0.027 & 0.065 & 0.014 & 0.064 & 0.067 & 0.020 & 0.182 & 0.034 & 0.104 & 0.428 & 0.347 & 0.388 & 0.279 & 0.181 & 0.146 \\
\hline
\end{tabular}




\begin{tabular}{|c|c|c|c|c|c|c|c|c|c|c|c|c|c|c|c|c|c|c|c|c|c|}
\hline Sample & 26577 & & 25386 & & & & & & & & & & & & & & & & & & 25395 \\
\hline $\mathrm{SiO}_{2}$ (wt.\%) & 37.22 & 36.32 & 36.45 & 36.45 & 35.52 & 36.81 & 36.48 & 37.11 & 36.10 & 36.62 & 36.05 & 36.12 & 36.35 & 35.94 & 36.26 & 35.92 & 35.73 & 36.10 & 36.27 & 36.21 & 35.56 \\
\hline $\mathrm{TiO}_{2}$ & 0.62 & 0.80 & 0.54 & 0.47 & 0.68 & 0.21 & 0.29 & 0.38 & 0.80 & 0.42 & 0.46 & 1.03 & 0.97 & 0.77 & 0.79 & 0.49 & 0.50 & 0.39 & 0.36 & 0.44 & 1.24 \\
\hline $\mathrm{Al}_{2} \mathrm{O}_{3}$ & 31.82 & 29.94 & 29.18 & 29.38 & 25.89 & 30.34 & 30.43 & 29.34 & 28.90 & 29.83 & 29.37 & 28.40 & 28.35 & 26.37 & 29.32 & 27.32 & 26.43 & 27.02 & 27.46 & 26.86 & 25.24 \\
\hline MgO & 5.13 & 4.81 & 6.81 & 7.26 & 5.75 & 7.22 & 7.20 & 6.68 & 6.09 & 7.09 & 6.98 & 5.94 & 5.75 & 5.87 & 6.96 & 6.05 & 5.94 & 5.87 & 6.19 & 6.08 & 5.29 \\
\hline MnO & 0.00 & 0.00 & 0.00 & 0.00 & 0.09 & 0.01 & 0.04 & 0.03 & 0.02 & 0.02 & 0.06 & 0.03 & 0.00 & 0.03 & 0.01 & 0.02 & 0.06 & 0.05 & 0.07 & 0.05 & 0.02 \\
\hline $\mathrm{FeO}^{\mathrm{a}}$ & 8.74 & 10.51 & 8.91 & 8.53 & 13.64 & 8.58 & 8.58 & 8.97 & 10.54 & 8.87 & 8.83 & 10.64 & 11.07 & 13.50 & 9.22 & 12.34 & 13.13 & 13.13 & 12.05 & 12.79 & 15.39 \\
\hline $\mathrm{CaO}$ & 0.20 & 0.20 & 0.98 & 1.27 & 0.40 & 1.24 & 1.27 & 0.95 & 0.56 & 1.08 & 1.17 & 0.43 & 0.22 & 0.43 & 1.36 & 0.44 & 0.44 & 0.39 & 0.42 & 0.48 & 0.65 \\
\hline $\mathrm{Na}_{2} \mathrm{O}$ & 1.95 & 2.18 & 2.05 & 2.16 & 2.59 & 2.11 & 2.07 & 2.15 & 2.34 & 2.08 & 2.11 & 2.51 & 2.63 & 2.61 & 2.02 & 2.58 & 2.55 & 2.57 & 2.57 & 2.52 & 2.47 \\
\hline $\mathrm{K}_{2} \mathrm{O}$ & 0.03 & 0.01 & 0.02 & 0.01 & 0.03 & 0.01 & 0.02 & 0.01 & 0.02 & 0.00 & 0.01 & 0.01 & 0.05 & 0.02 & 0.00 & 0.03 & 0.04 & 0.04 & 0.04 & 0.04 & 0.03 \\
\hline$F$ & 0.00 & 0.00 & 0.00 & 0.00 & 0.00 & 0.00 & 0.00 & 0.00 & 0.00 & 0.00 & 0.00 & 0.00 & 0.00 & 0.00 & 0.00 & 0.00 & 0.00 & 0.00 & 0.00 & 0.00 & 0.00 \\
\hline $\mathrm{Cl}$ & 0.00 & 0.01 & 0.01 & 0.00 & 0.00 & 0.01 & 0.00 & 0.01 & 0.00 & 0.00 & 0.00 & 0.00 & 0.00 & 0.00 & 0.00 & 0.00 & 0.00 & 0.00 & 0.00 & 0.00 & 0.02 \\
\hline $\mathrm{Cr}_{2} \mathrm{O}_{3}$ & 0.04 & 0.03 & 0.02 & 0.00 & 0.01 & 0.00 & 0.01 & 0.01 & 0.04 & 0.04 & 0.02 & 0.07 & 0.07 & 0.02 & 0.02 & 0.04 & 0.04 & 0.03 & 0.00 & 0.02 & 0.03 \\
\hline Sum & 85.73 & 84.81 & 84.97 & 85.52 & 84.58 & 86.54 & 86.38 & 85.63 & 85.42 & 86.04 & 85.06 & 85.17 & 85.46 & 85.57 & 85.96 & 85.23 & 84.84 & 85.59 & 85.42 & 85.50 & 85.95 \\
\hline$O=F$ & 0.00 & 0.00 & 0.00 & 0.00 & 0.00 & 0.00 & 0.00 & 0.00 & 0.00 & 0.00 & 0.00 & 0.00 & 0.00 & 0.00 & 0.00 & 0.00 & 0.00 & 0.00 & 0.00 & 0.00 & 0.00 \\
\hline Total & & & 84.97 & 85.52 & 84.58 & 86.54 & 86.37 & 85.63 & 85.42 & 86.04 & 85.06 & 85.17 & 85.46 & 85.57 & 85.96 & 85.23 & 84.84 & 85.59 & 85.42 & 85.50 & 85.95 \\
\hline Si (Atoms p.f.u.) & 6.193 & 6.178 & 6.152 & 6.117 & 6.153 & 6.111 & 6.152 & 6.117 & 6.105 & 6.096 & 6.086 & 6.147 & 6.173 & 6.149 & 6.076 & 6.133 & 6.150 & 6.153 & 6.164 & 6.171 & 6.129 \\
\hline $\operatorname{Al}(T)$ & 0.000 & 0.000 & 0.000 & 0.000 & 0.000 & 0.000 & 0.000 & 0.000 & 0.000 & 0.000 & 0.000 & 0.000 & 0.000 & 0.000 & 0.000 & 0.000 & 0.000 & 0.000 & 0.000 & 0.000 & 0.000 \\
\hline $\operatorname{Al}(\mathrm{Z})$ & 6.000 & 6.000 & 5.807 & 5.812 & 5.286 & 5.961 & 5.807 & 5.812 & 5.763 & 5.854 & 5.845 & 5.697 & 5.676 & 5.318 & 5.793 & 5.499 & 5.363 & 5.428 & 5.501 & 5.397 & 5.128 \\
\hline $\mathrm{Al}(\mathrm{Y})$ & 0.242 & 0.005 & 0.000 & 0.000 & 0.000 & 0.000 & 0.000 & 0.000 & 0.000 & 0.000 & 0.000 & 0.000 & 0.000 & 0.000 & 0.000 & 0.000 & 0.000 & 0.000 & 0.000 & 0.000 & 0.000 \\
\hline $\mathrm{Ti}$ & 0.077 & 0.102 & 0.068 & 0.059 & 0.089 & 0.046 & 0.068 & 0.059 & 0.102 & 0.053 & 0.058 & 0.132 & 0.124 & 0.099 & 0.099 & 0.063 & 0.065 & 0.050 & 0.045 & 0.057 & 0.161 \\
\hline Mg & 1.271 & 1.220 & 1.714 & 1.814 & 1.484 & 1.751 & 1.714 & 1.814 & 1.536 & 1.759 & 1.756 & 1.506 & 1.456 & 1.498 & 1.738 & 1.539 & 1.524 & 1.490 & 1.568 & 1.545 & 1.359 \\
\hline Mn & 0.000 & 0.000 & 0.000 & 0.000 & 0.013 & 0.000 & 0.000 & 0.000 & 0.003 & 0.002 & 0.008 & 0.004 & 0.000 & 0.004 & 0.002 & 0.003 & 0.009 & 0.007 & 0.010 & 0.007 & 0.004 \\
\hline $\mathrm{Fe}$ & 1.217 & 1.494 & 1.258 & 1.198 & 1.976 & 1.131 & 1.258 & 1.198 & 1.491 & 1.235 & 1.246 & 1.514 & 1.572 & 1.932 & 1.292 & 1.762 & 1.890 & 1.871 & 1.712 & 1.823 & 2.219 \\
\hline $\mathrm{Ca}$ & 0.035 & 0.036 & 0.178 & 0.228 & 0.073 & 0.176 & 0.178 & 0.228 & 0.101 & 0.193 & 0.212 & 0.078 & 0.041 & 0.079 & 0.244 & 0.080 & 0.080 & 0.072 & 0.076 & 0.087 & 0.121 \\
\hline $\mathrm{Na}$ & 0.628 & 0.719 & 0.670 & 0.701 & 0.870 & 0.688 & 0.670 & 0.701 & 0.768 & 0.672 & 0.690 & 0.827 & 0.867 & 0.864 & 0.655 & 0.853 & 0.850 & 0.850 & 0.848 & 0.833 & 0.827 \\
\hline K & 0.006 & 0.002 & 0.005 & 0.002 & 0.006 & 0.000 & 0.005 & 0.002 & 0.005 & 0.000 & 0.001 & 0.003 & 0.010 & 0.005 & 0.001 & 0.005 & 0.008 & 0.010 & 0.008 & 0.008 & 0.006 \\
\hline X-site vacancies & 0.332 & 0.243 & 0.147 & 0.069 & 0.051 & 0.136 & 0.147 & 0.069 & 0.126 & 0.135 & 0.096 & 0.093 & 0.082 & 0.052 & 0.100 & 0.061 & 0.061 & 0.068 & 0.068 & 0.072 & 0.046 \\
\hline
\end{tabular}


Electronic Supplementary Material

Table 2. (Continued)

\begin{tabular}{|c|c|c|c|c|}
\hline Sample & 25395 & & & \\
\hline $\mathrm{SiO}_{2}$ (wt.\%) & 35.32 & 36.12 & 38.98 & 35.34 \\
\hline $\mathrm{TiO}_{2}$ & 0.81 & 0.81 & 0.41 & 0.68 \\
\hline $\mathrm{Al}_{2} \mathrm{O}_{3}$ & 25.27 & 26.57 & 25.23 & 26.33 \\
\hline MgO & 5.25 & 5.25 & 5.13 & 5.66 \\
\hline MnO & 0.01 & 0.05 & 0.02 & 0.04 \\
\hline $\mathrm{FeO}^{\mathrm{a}}$ & 15.46 & 13.58 & 13.38 & 13.68 \\
\hline $\mathrm{CaO}$ & 0.77 & 0.63 & 0.50 & 0.46 \\
\hline $\mathrm{Na}_{2} \mathrm{O}$ & 2.44 & 2.44 & 2.29 & 2.57 \\
\hline $\mathrm{K}_{2} \mathrm{O}$ & 0.04 & 0.02 & 0.02 & 0.02 \\
\hline $\mathbf{F}$ & 0.00 & 0.00 & 0.00 & 0.00 \\
\hline $\mathrm{Cl}$ & 0.00 & 0.00 & 0.01 & 0.00 \\
\hline $\mathrm{Cr}_{2} \mathrm{O}_{3}$ & 0.03 & 0.09 & 0.03 & 0.04 \\
\hline Sum & 85.40 & 85.54 & 86.01 & 84.82 \\
\hline$O=F$ & 0.00 & 0.00 & 0.00 & 0.00 \\
\hline Total & 85.40 & 85.54 & 86.01 & 84.82 \\
\hline Si (Atoms p.f.u.) & 6.126 & 6.208 & 6.653 & 6.106 \\
\hline $\operatorname{Al}(T)$ & 0.000 & 0.000 & 0.000 & 0.000 \\
\hline $\operatorname{Al}(\mathrm{Z})$ & 5.168 & 5.385 & 5.077 & 5.364 \\
\hline $\operatorname{Al}(Y)$ & 0.000 & 0.000 & 0.000 & 0.000 \\
\hline $\mathrm{Ti}$ & 0.106 & 0.104 & 0.052 & 0.088 \\
\hline Mg & 1.356 & 1.344 & 1.306 & 1.459 \\
\hline Mn & 0.002 & 0.007 & 0.003 & 0.006 \\
\hline $\mathrm{Fe}$ & 2.243 & 1.952 & 1.910 & 1.977 \\
\hline $\mathrm{Ca}$ & 0.143 & 0.117 & 0.091 & 0.085 \\
\hline $\mathrm{Na}$ & 0.819 & 0.812 & 0.756 & 0.862 \\
\hline K & 0.008 & 0.004 & 0.005 & 0.004 \\
\hline $\mathrm{X}$-site vacancies & 0.030 & 0.067 & 0.148 & 0.049 \\
\hline
\end{tabular}




\begin{tabular}{|c|c|c|c|c|c|c|c|c|c|}
\hline Analysis No. & Date & ${ }^{11} \mathrm{~B} /{ }^{10} \mathrm{~B}$ & $1 \sigma(\% \circ)^{a}$ & $\operatorname{IMF}(\% 0)^{\mathrm{D}}$ & Analysis No. & Date & ${ }^{11} \mathrm{~B} /{ }^{10} \mathrm{~B}$ & $1 \sigma(\% 0)^{a}$ & $\operatorname{IMF}(\% \circ)^{\mathrm{D}}$ \\
\hline SCHORL & & & & & DRAVITE & & & & \\
\hline Tour 002 & 02.05.2006 & 3.801 & 0.54 & -48.1 & Tour 004 & 02.05 .2006 & 3.820 & 0.73 & -49.0 \\
\hline Tour 005 & 02.05.2006 & 3.807 & 0.65 & -46.6 & Tour 010 & 02.05 .2006 & 3.824 & 0.73 & -48.0 \\
\hline Tour 008 & 02.05.2006 & 3.803 & 0.57 & -47.6 & Tour 013 & 03.05 .2006 & 3.822 & 0.70 & -48.5 \\
\hline Tour 011 & 03.05 .2006 & 3.802 & 0.50 & -47.9 & Tour 020 & 03.05 .2006 & 3.821 & 0.60 & -48.8 \\
\hline Tour 014 & 03.05.2006 & 3.804 & 0.43 & -47.4 & Tour 025 & 03.05.2006 & 3.822 & 0.68 & -48.5 \\
\hline Tour 018 & 03.05.2006 & 3.807 & 0.53 & -46.6 & Tour 028 & 04.05 .2006 & 3.825 & 0.71 & -47.8 \\
\hline Tour 021 & 03.05.2006 & 3.802 & 0.62 & -47.9 & Tour 031 & 04.05 .2006 & 3.821 & 0.78 & -48.8 \\
\hline Tour 026 & 03.05.2006 & 3.804 & 0.56 & -47.4 & Tour 034 & 04.05 .2006 & 3.819 & 0.67 & -49.3 \\
\hline Tour 027 & 04.05 .2006 & 3.802 & 0.65 & -47.9 & Tour 038 & 05.05.2006 & 3.819 & 0.62 & -49.3 \\
\hline Tour 030 & 04.05 .2006 & 3.803 & 0.51 & -47.6 & Tour 041 & 05.05 .2006 & 3.821 & 0.66 & -48.8 \\
\hline Tour 036 & 04.05 .2006 & 3.798 & 0.44 & -48.9 & Tour 047 & 05.05 .2006 & 3.812 & 0.64 & -51.0 \\
\hline Tour 037 & 05.05 .2006 & 3.799 & 0.53 & -48.6 & Mean & & 3.821 & & \\
\hline Tour 043 & 05.05 .2006 & 3.797 & 0.51 & -49.1 & Ext. precision & $\sigma$ in \%o $)^{c}$ & 0.887 & & \\
\hline Tour 046 & 05.05 .2006 & 3.796 & 0.57 & -49.4 & & & & & \\
\hline Mean & & 3.802 & & & B4 & & & & \\
\hline \multicolumn{2}{|c|}{ Ext. precision $(1 \sigma \text { in } \% 0)^{c}$} & 0.883 & & & Tour 003 & 02.05 .2006 & 3.817 & 0.50 & -47.6 \\
\hline & & & & & Tour 007 & 02.05 .2006 & 3.824 & 0.61 & -45.9 \\
\hline & & & & & Tour 009 & 02.05 .2006 & 3.825 & 0.60 & -45.6 \\
\hline ELBAITE & & & & & Tour 012 & 03.05 .2006 & 3.821 & 0.60 & -46.6 \\
\hline Tour 016 & 03.05.2006 & 3.808 & 0.65 & -48.3 & Tour 017 & 03.05 .2006 & 3.824 & 0.51 & -45.9 \\
\hline Tour 019 & 03.05.2006 & 3.796 & 0.62 & -51.3 & Tour 022 & 03.05 .2006 & 3.822 & 0.48 & -46.4 \\
\hline Tour 023 & 03.05 .2006 & 3.791 & 0.51 & -52.6 & Tour 024 & 03.05.2006 & 3.823 & 0.70 & -46.1 \\
\hline Tour 032 & 04.05 .2006 & 3.801 & 0.58 & -50.1 & Tour 029 & 04.05 .2006 & 3.819 & 0.67 & -47.1 \\
\hline Tour 033 & 04.05 .2006 & 3.800 & 0.55 & -50.3 & Tour 035 & 04.05 .2006 & 3.817 & 0.67 & -47.6 \\
\hline Tour 040 & 05.05 .2006 & 3.799 & 0.58 & -50.6 & Tour 039 & 05.05 .2006 & 3.820 & 0.70 & -46.9 \\
\hline Tour 044 & 05.05 .2006 & 3.803 & 0.50 & -49.6 & Tour 042 & 05.05 .2006 & 3.819 & 0.60 & -47.1 \\
\hline Tour 045 & 05.05 .2006 & 3.800 & 0.64 & -50.3 & Tour 048 & 05.05 .2006 & 3.813 & 0.58 & -48.6 \\
\hline Mean & & 3.800 & & & Mean & & 3.820 & & \\
\hline \multicolumn{2}{|c|}{ Ext. precision $(1 \sigma \text { in } \% \circ)^{c}$} & 1.303 & & & \multicolumn{2}{|c|}{ Ext. precision $(1 \sigma \text { in } \%)^{c}$} & 0.929 & & \\
\hline \multicolumn{5}{|l|}{ SCHORL } & \multicolumn{3}{|l|}{ DRAVITE } & & \\
\hline Tour002 & 07.07 .2006 & 3.860 & 0.51 & -33.3 & Tour003 & 07.07.2006 & 3.881 & 0.69 & -33.8 \\
\hline Tour012 & 07.07 .2006 & 3.853 & 0.59 & -35.1 & Tour013 & 07.07.2006 & 3.877 & 0.67 & -34.8 \\
\hline Tour027 & 07.07 .2006 & 3.853 & 0.57 & -35.1 & Tour028 & 07.07.2006 & 3.876 & 0.72 & -35.1 \\
\hline Mean & & 3.855 & & & Mean & & 3.878 & & \\
\hline \multicolumn{2}{|c|}{ Ext. precision $(1 \sigma \text { in } \% \text { o })^{c}$} & 1.048 & & & \multicolumn{2}{|c|}{ Ext. precision $(1 \sigma \text { in } \%)^{c}$} & 0.682 & & \\
\hline ELBAITE & & & & & B4 & & & & \\
\hline Tour001 & 07.07.2006 & 3.857 & 0.60 & -36.1 & Tour004 & 07.07.2006 & 3.877 & 0.66 & -32.6 \\
\hline Tour011 & 07.07.2006 & 3.853 & 0.53 & -37.1 & Tour014 & 07.07.2006 & 3.869 & 0.60 & -34.6 \\
\hline Tour026 & 07.07.2006 & 3.850 & 0.57 & -37.8 & Tour029 & 07.07.2006 & 3.869 & 0.54 & -34.6 \\
\hline \multirow{2}{*}{\multicolumn{2}{|c|}{$\begin{array}{l}\text { Mean } \\
\text { Ext. precision }(1 \sigma \text { in } \%)^{c}\end{array}$}} & 3.853 & & & \multirow{2}{*}{\multicolumn{2}{|c|}{$\begin{array}{l}\text { Mean } \\
\text { Ext. precision }(1 \sigma \text { in } \%)^{c}\end{array}$}} & 3.872 & & \\
\hline & & 0.911 & & & & & 1.193 & & \\
\hline
\end{tabular}

